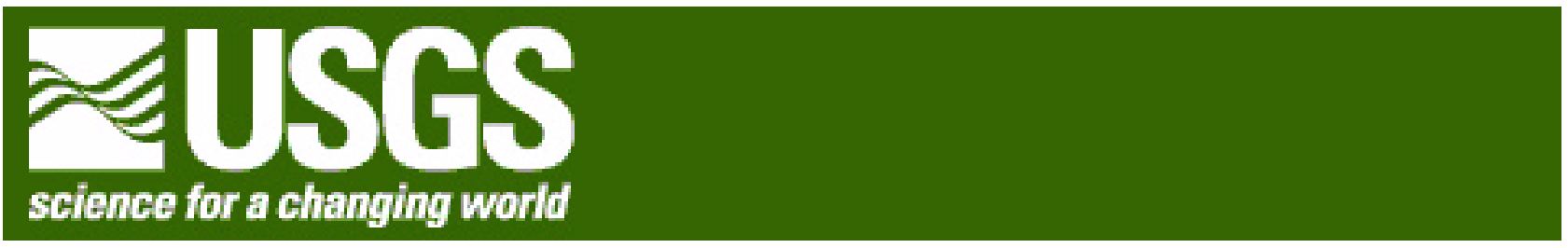

\title{
Location, Age, and Tectonic Significance of the Western Idaho Suture Zone (WISZ)
}

\author{
By Robert J. Fleck ${ }^{1}$ and Robert E. Criss $^{2}$
}

Open-File Report 2004-1039

Any use of trade names is for descriptive purposes only and does not imply endorsement by the Federal Government.

\section{U.S. Department of the Interior U.S. Geological Survey}

${ }^{1}$ U.S. Geological Survey, 345 Middlefield Road (MS 937), Menlo Park, CA 94025

${ }^{2}$ Department of Earth and Planetary Sciences, Washington University, Campus Box 1169, St. Louis, MO 63130 


\title{
LOCATION, AGE, AND TECTONIC SIGNIFICANCE OF THE WESTERN IDAHO SUTURE ZONE (WISZ)
}

\author{
By ROBERT J. FLECK and ROBERT E. CRISS
}

\begin{abstract}
The Western Idaho Suture Zone (WISZ) represents the boundary between crust overlying Proterozoic North American lithosphere and Late Paleozoic and Mesozoic intraoceanic crust accreted during Cretaceous time. Highly deformed plutons constituted of both arc and sialic components intrude the WISZ and in places are thrust over the accreted terranes. Pronounced variations in $\mathrm{Sr}, \mathrm{Nd}$, and $\mathrm{O}$ isotope ratios and in major and trace element composition occur across the suture zone in Mesozoic plutons. The WISZ is located by an abrupt west to east increase in initial ${ }^{87} \mathrm{Sr} /{ }^{86} \mathrm{Sr}$ ratios, traceable for over $300 \mathrm{~km}$ from eastern Washington near Clarkston, east along the Clearwater River thorough a bend to the south of about $110^{\circ}$ from Orofino Creek to Harpster, and extending south-southwest to near Ola, Idaho, where Columbia River basalts conceal its extension to the south. K-Ar and ${ }^{40} \mathrm{Ar} /{ }^{39} \mathrm{Ar}$ apparent ages of hornblende and biotite from Jurassic and Early Cretaceous plutons in the accreted terranes are highly discordant within about $10 \mathrm{~km}$ of the WISZ, exhibiting patterns of thermal loss caused by deformation, subsequent batholith intrusion, and rapid rise of the continental margin. Major crustal movements within the WISZ commenced after about $135 \mathrm{Ma}$, but much of the displacement may have been largely vertical, during and following emplacement of batholithscale silicic magmas. Deformation continued until at least $85 \mathrm{Ma}$ and probably until $74 \mathrm{Ma}$, progressing from south to north.
\end{abstract}

\section{INTRODUCTION}

Geologic investigations of western Idaho and eastern Oregon and Washington have disclosed the presence of several tectonostratigraphic terranes, referred to here collectively as the Wallowa-Seven Devils (WSD) terranes, representing Late Paleozoic-Mesozoic island-arc complexes accreted to North America in Cretaceous time (Hamilton, 1976; Jones and others, 1977; Vallier, 1977; Fleck and Criss, 1985; Lund and Snee, 1988; Snee and others, 1995). The classic Sr-isotope and geochronologic study by Armstrong et al. (1977) demonstrated that plutons intruding these arc terranes are distinct from those intruding the Precambrian crust of North America. Subsequent studies by Fleck and Criss (1985), Criss and Fleck (1987), Fleck (1990), and Manduca and others $(1992,1993)$ generally confirm these relationships and provide abundant data on the isotope geochemistry and age of plutonic rocks of the region, as well as on the character of their sources and the terranes through which they were emplaced.

This study focuses on the location, age, and character of the tectonic boundary between the North American craton and the WSD terranes. Although inferred to extend from southeastern Washington to the Snake River Plain, exposures of this boundary are recognized in western Idaho from near Ahsahka in the north to near Gross, ID in the south. Because the suture boundary is confined to western Idaho over its recognized length, but is not well located by any other geographic feature, the structure is referred to here as the western Idaho suture zone or WISZ (Strayer and Hyndman, D.W., 1987; Strayer and others, 1988; Fleck and Criss, 1988; Strayer and others, 1989; Fleck, 1990). The name "Salmon River suture" has also been used for the zone (Lund and Snee, 1988) in west-central Idaho, but because the Salmon River is one of several geographic features that cross the suture at almost $90^{\circ}$, we do not consider the name 
adequately representative. McCelland and others (2000) have used "western Idaho shear zone" for the "late-stage", mylonitic part of the terrane boundary, essentially consistent with the use of WISZ here, but use "Salmon River suture zone" to incorporate the belt of Cretaceous(?) thrust faults within the WSD terranes into their definition of the suture. We confine our usage of Western Idaho suture zone to the highly strained and metamorphosed rocks of the terrane boundary zone, recognized by their degree of deformation and an abrupt transition of geochemical and isotopic characteristics from intraoceanic island-arc to North American craton. We accept that many of the plutons now representing the zone were emplaced subsequent to the initial suturing events, which may not have been synchronous along the $>280 \mathrm{~km}$ length of the suture.

\section{ACKNOWLEDGMENTS}

We thank Ron Kistler and Andy Calvert for helpful discussions and reviews of the manuscript. Susan Gunn, Elliot Kollman, and Betsy Rosenberg assisted with Rb-Sr and Sm-Nd analyses. Jarel Von Essen, James Saburomaru, and Elliot Kollman performed argon analyses and sample preparation. Paul Klock, David Vivit, and Terry Fries performed potassium

analyses. James Saburomaru prepared samples for irradiation and performed ${ }^{40} \mathrm{Ar} /{ }^{39} \mathrm{Ar}$ analyses. Don Shamp assisted with data compilation.

\section{REGIONAL RELATIONSHIPS GEOLOGIC SETTING}

The western limit of Precambrian rocks of North American cratonal terranes in Idaho south of the Clearwater River occurs at about $116^{\circ} \mathrm{W}$ long, but bends abruptly westward north of the river, cropping out discontinuously from beneath Columbia River basalt flows into eastern Washington (Fig. 1). West and south of this limit, the oldest rocks are Devonian to Permian suites of sedimentary shelf deposits, dismembered oceanic crust, and volcanic/plutonic arc rocks (Vallier et al., 1977; Beaulieu, 1974; Walker, 1977; Mullen, 1985), representing an intraoceanic assemblage of depositionally and tectonically juxtaposed igneous and sedimentary units. The boundary between these distinct crustal types is a highly deformed, often mylonitic zone with anastomosing fractures, cataclasis, and recrystallization (Myers, 1982; Strayer and others, 1989), representing the "suture" between North American cratonal terranes and the WSD terranes (Fleck and Criss, 1985; Criss and Fleck, 1987; Fleck, 1990, Manduca and others (1992; 1993), McCelland and others, 2000). The character of rocks proximal to the suture zone is key to understanding the WISZ. Rocks of both terrane groups were variably metamorphosed, reaching upper amphibolite grade with $\mathrm{P}-\mathrm{T}$ conditions up to $600^{\circ} \mathrm{C}$ and 8 to 9 kbar near the suture (Myers, 1982; Lund and Snee, 1988; Selverstone and others, 1992; Getty and others, 1993). WDS terranes only reached these highest grades in proximity to the suture, whereas contact metamorphic effects of plutons of the Idaho batholith extend high-temperature isograds well into the Precambrian terrane (e.g., Hietanen (1962, 1963a, 1963b; Myers, 1982). Studies of the Idaho batholith and cratonal terrane in the region of the WISZ include Hietanen (1962, 1963a, 1963b, 1967), Myers (1982), Wiswall and Hyndman (1987), Lund and Snee (1988), Manduca and others (1992; 1993), and Lund (1995). The WSD terranes are discussed by Hamilton (1963a,b), Taubeneck (1971), Beaulieu (1974), Vallier and others (1977), Brooks and Vallier (1978), Ave Lallemant and others (1980, 1985), Mullen (1985), Onasch (1987), Manduca and others (1992; 1993), and Lund (1995). 
TOPO! map printed on 06/20/03 from "wisz fig 1.tpo" and "Untitled.tpg"

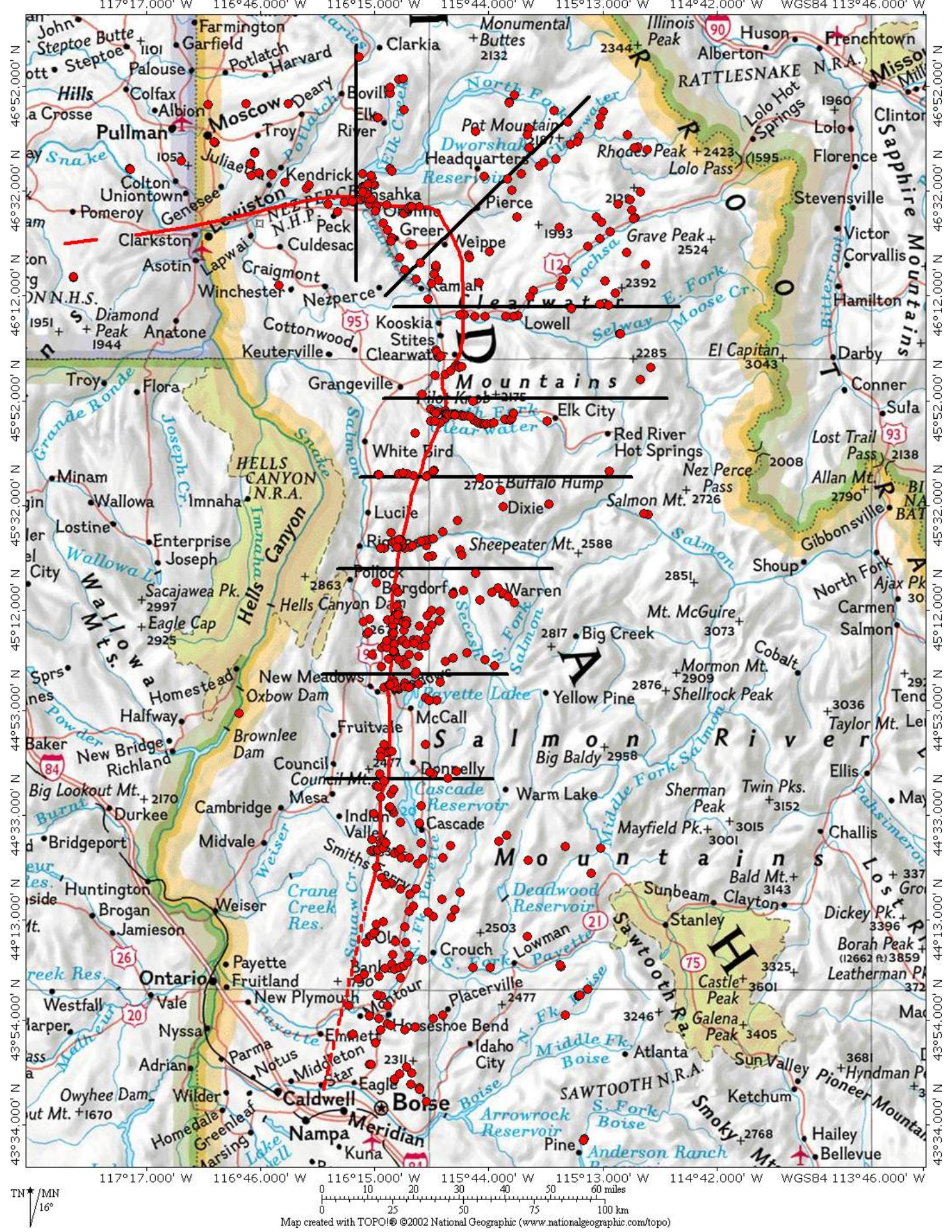

Figure 1. Location map of the western Idaho suture zone (WISZ) and age traverses across it from the Late Paleozoic and Mesozoic accreted terranes on the south or west to the cratonal terranes of Mesozoic North America on the north and east. The WISZ occurs near the western margin of the Idaho batholith over much of its length. 
Volumes edited by Vallier and Brooks (1987; 1995) include important studies of both the WSD and cratonal terranes, as well as specific studies of the suture zone (WISZ). In the first of these volumes Criss and Fleck provide K-Ar and ${ }^{40} \mathrm{Ar} /{ }^{39} \mathrm{Ar}$ results for rocks of north-central Idaho, including samples from the suture zone. These ages constrain the age of suturing to the period between $135 \mathrm{Ma}$ and $75 \mathrm{Ma}$, suggesting a most probable range of $95 \mathrm{Ma}$ to $80 \mathrm{Ma}$. Lund and Snee (1988) concluded that suturing occurred between $118 \mathrm{Ma}$ and $93 \mathrm{Ma}$, based on ${ }^{40} \mathrm{Ar} /{ }^{39} \mathrm{Ar}$ ages of metamorphic rocks of the WSD terranes and undeformed plutons in and adjacent to the WISZ. Getty and others (1993) report Sm-Nd ages from 144 Ma to 128 Ma for garnet amphibolites formed during metamorphism of the accreted terranes. They interpret the $128 \pm 3$ Ma age to represent the time of peak metamorphism, with the ${ }^{40} \mathrm{Ar} /{ }^{39} \mathrm{Ar}$ age of $118 \mathrm{Ma}$ for coexisting hornblende representing cooling subsequent to suturing. Manduca and others (1993) report the presence of supracrustal units from both the WSD and cratonal terranes in 110 \pm 5 Ma orthogneiss, supporting an earlier joining of these terranes. They also support a timing of arc-continent collision prior to $125 \mathrm{Ma}$. Snee and others (1995) report ${ }^{40} \mathrm{Ar} /{ }^{39} \mathrm{Ar}$ results for a suite of samples along the suture zone from south of its intersection with the Salmon River to where it crosses the South Fork of the Clearwater River. They argue that suturing was complete by $93 \mathrm{Ma}$, followed by rapid uplift of cratonal terranes. Contrary to results reported by Criss and Fleck (1987) farther north, they conclude that no plutonism occurred in the area between $88 \mathrm{Ma}$ and $78 \mathrm{Ma}$ during the major period of uplift. The results from all of these studies suggest that suturing of the WSD terranes to the North American craton was a prolonged event, with continuation of contractional deformation long after peak metamorphism. Late Cretaceous plutons with isotopic signatures of continental crust reflect tectonic emplacement and uplift of 10-20 km, indicating that major crustal movements occurred within the suture zone until at least 85 Ma (Myers, 1982; Criss and Fleck, 1987; Lund and Snee, 1988; Selverstone and others, 1992; Manduca and others, 1992, 1993). Snee and others (1995) report four periods of metamorphism between $130 \mathrm{Ma}$ and $101 \mathrm{Ma}$ with plutonism peaking at about $115 \mathrm{Ma}$ and $93 \mathrm{Ma}$ to $88 \mathrm{Ma}$ in the Slate Creek-Salmon River section of the WISZ. Most authors accept an age of 130 Ma to $115 \mathrm{Ma}$ for collision and accretion (suturing) of the WSD terrane to North America, but there is widespread evidence of continued deformation and intrusion along the WISZ after $95 \mathrm{Ma}$.

Plutonism within the WSD terranes occurred in three primary episodes: 270-215 Ma, 145$115 \mathrm{Ma}$, and 95-85 Ma, although a few Middle to Late Jurassic ages have been reported (Armstrong and others, 1977; Brooks and Vallier, 1978; Ave Lallemant and others, 1980; Criss and Fleck, 1987; Walker, 1995; Snee and others, 1995). Although most plutons reveal some evidence of subsequent deformation, mylonitization is only common in major shear zones such as the Oxbow shear zone (Vallier, 1974; Ave Lallemant and others, 1985), the Rapid River thrust (Hamilton, 1963a,b), and the WISZ. Only the latter involves rocks of the cratonal terrane, however. Although deformation and metamorphism of the rocks involved may have begun earlier, significant movement along these shear zones clearly postdated emplacement of the mylonitized plutons and peak metamorphism of the host terranes. Hamilton (1963a,b) and Ave Lallemant and others $(1980,1985)$ present strong evidence for at least two periods of metamorphism and mylonitization within the WSD terranes. A Late Triassic-Early Jurassic age is favored for the older of these events (Brooks and Vallier, 1978; Ave Lallemant and others, 1985). Deformation along the WISZ is not confined to the accreted terranes and represents an even younger period, continuing until at least 78 Ma (Fleck and Criss, 1987; Lund and Snee, 1988). 
THE WESTERN IDAHO SUTURE ZONE

The western Idaho suture zone (WISZ) is a highly deformed zone of near-vertical foliation, anastomosing fractures, cataclasis or mylonitization, recrystallization, and interleaved tectonic slivers (Myers, 1982; Hoover, 1986; Strayer and others, 1989; Manduca and others, 1992; 1993; Lund, 1995). Within this zone of extreme deformation Late Paleozoic and Mesozoic volcanic and sedimentary rocks are complexly sheared and tectonically juxtaposed with Proterozoic gneisses and schists and Cretaceous granitoids emplaced during or prior to deformation (Myers, 1982). The WISZ is recognizable not only by its juxtaposition of distinct rock types and its degree of deformation, but also by geochemical and isotopic variations in plutons emplaced within and through the two different crustal types. Armstrong and others (1977) first documented the large change in initial ${ }^{87} \mathrm{Sr} /{ }^{86} \mathrm{Sr}$ ratio $\left(\mathrm{Sr}_{\mathrm{i}}\right)$ of plutons in this part of Idaho. Further investigation by Fleck and Criss (1985) revealed that, although abrupt, the west to east increase in initial ratios was not discontinuous, but that the low $(<0.704)$ ratios characteristic of plutons intruding the WSD terranes give way almost continuously to the high $(>0.708)$ values characteristic of magmas emplaced through Precambrian sialic crust. Fleck (1990) demonstrated that $\mathrm{E}_{\mathrm{Nd}}$ decreases across this narrow zone, almost antithetic to the $\mathrm{Sr}_{\mathrm{i}}$ increase, from values of about +6 to below -8 . This change in $\mathrm{Sr}$ and $\mathrm{Nd}$ initial-ratios occurs across a 5- to 15-km-wide zone that coincides with the WISZ. Plutons intruding this narrow transition zone have inherited their geochemical characteristics from both of the crustal types (Fleck and Criss, 1985; Fleck, 1990).

Data presented by Fleck and Criss (1985), Criss and Fleck (1987), Fleck (1990), and Manduca and others (1992, 1993) demonstrate both chemical and isotopic variations across the WISZ. In addition to the variations in $\mathrm{Sr}_{\mathrm{i}}$ and $\mathrm{E}_{\mathrm{Nd}}$, whole-rock $\delta^{18} \mathrm{O}$ values of plutons increase systematically from +5.5 to +8.0 in the WSD terranes to +9.0 to +12.5 in the Precambrian-hosted Idaho batholith, changing continuously across the WISZ. Systematic west to east changes also occur in $\delta \mathrm{D}$ values, $\mathrm{Rb} / \mathrm{Sr}$ ratios, and in $\mathrm{SiO}_{2}, \mathrm{Al}_{2} \mathrm{O}_{3}$, and $\mathrm{K}_{2} \mathrm{O}$ contents of plutons within the WISZ (Criss and Fleck, 1987). Fleck (1990) demonstrated west to east increases in Nd, Sm, Y, and $\mathrm{Nb}$, and concomitant decreases in $\mathrm{E}_{\mathrm{Nd}}$ and $\mathrm{Sr} / \mathrm{Sm}$.

\section{ISOTOPIC RESULTS}

$\mathrm{Sr}$ and Nd isotopic results obtained in this study for plutonic rocks of western Idaho are compatible with our earlier results (Fleck and Criss, 1985; Criss and Fleck, 1987; Fleck, 1990), demonstrating the similarity of the crustal signatures of the cratonal and accreted terranes along the length of the suture zone. The similarities must also extend in at least a general way to the sources of the magmas from which the plutons of each terrane were derived and to the processes of crystallization and assimilation affecting the final products. The broad similarity over the nearly $300 \mathrm{~km}$ length of the suture zone reinforces the usefulness of isotopic tracers as a means of locating and identifying the suture zone throughout western Idaho. Isotopic data from previous studies have been incorporated in this study, but are not tabulated here. Discussions of the chemical and isotopic variations and their significance to magma sources are covered in greater detail in Fleck (1990) for rocks of the South Fork of the Clearwater River (SFCR).

Analytical techniques used in this study were essentially the same as reported by Fleck and Criss (1985) and Fleck (1990). All Sm and Nd concentrations and some Rb and Sr concentrations were determined by isotope dilution. Sr and $\mathrm{Nd}$ isotopic ratios were measured by double collection on a Finnigan-MAT 261 thermal-ionization mass spectrometer. Uncertainties in measured ${ }^{87} \mathrm{Sr} /{ }^{86} \mathrm{Sr}$ were commonly $\pm 25 \mathrm{ppm}(2 \sigma$ mean $)$. For Sr calculations, $\lambda_{\mathrm{Rb}}=1.42 \times 10^{-}$ 
${ }^{11} \mathrm{yr}^{-1},\left({ }^{87} \mathrm{Sr} /{ }^{86} \mathrm{Sr}\right)_{\mathrm{CHUR}}=0.7045$, and $\left({ }^{87} \mathrm{Rb} /{ }^{86} \mathrm{Sr}\right)_{\mathrm{CHUR}}=0.0839$. Uncertainties in ${ }^{143} \mathrm{Nd} /{ }^{144} \mathrm{Nd}$ ratios averaged $\pm 35 \mathrm{ppm}$ ( $2 \sigma$ mean), equivalent to $\pm 0.35 \mathrm{E}_{\mathrm{Nd}}$ units. Constants used in $\mathrm{Nd}$ calculations were: $\lambda_{\mathrm{Sm}}=6.54 \times 10^{-12} \mathrm{yr}^{-1},\left({ }^{143} \mathrm{Nd} /{ }^{144} \mathrm{Nd}\right)_{\mathrm{CHUR}}=0.51264$, and $\left({ }^{147} \mathrm{Sm} /{ }^{144} \mathrm{Nd}\right)_{\mathrm{CHUR}}=$ 0.1967. Where used here, $\mathrm{E}_{\mathrm{Sr}}$ and $\mathrm{E}_{\mathrm{Nd}}$ are calculated in the usual manner relative to a model undisturbed chondritic reservoir CHUR, (DePaolo and Wasserburg, 1976, 1979). $\mathrm{E}_{\mathrm{Nd}}(\mathrm{t})$ designates $\mathrm{E}_{\mathrm{Nd}}$ at the age of the rock, analogous to an initial ratio. Sr isotopic results and location information are shown in Table 1 and Nd results appear in Table 2. New K-Ar and ${ }^{40} \mathrm{Ar} /{ }^{39} \mathrm{Ar}$ age determinations are reported in Tables 3 and 4, respectively.

\section{CHEMICAL AND ISOTOPIC CHARACTERISTICS}

Studies of both plutonic rocks and their wall rock hosts exposed along the South Fork of the Clearwater River (SFCR) by Myers (1982), Fleck and Criss (1985), Hoover (1986), Criss and Fleck (1987), and Fleck (1990) have provided a detailed characterization of chemical and isotopic variations across the terrane boundary between Precambrian crust and Late PaleozoicMesozoic island arc rocks. Similar studies by Lund and Snee (1988) and Manduca and others (1992, 1993) characterize this suture zone farther south in the area of McCall, ID. This boundary, the western Idaho suture zone or WISZ, was formed when arc-derived terranes were accreted to the North American craton in Cretaceous time. Combined with the earlier studies, the isotopic results permit identification of the WISZ throughout western Idaho even where the boundary zone itself is completely obscured by younger plutons, young basalt flows, or alluviated valleys. Clearly, these studies cannot replace careful geologic mapping of the suture, but provide both a guide and confirmation for those studies.

\section{UNIQUE CHARACTER OF SUTURE ZONE MAGMAS}

Fleck and Criss (1985) and Fleck (1990) have presented evidence of multiple components in plutons of the SFCR, whose proportions vary geographically across the WISZ. Hart (1985) reported similar results for basaltic rocks that cross the presumed southwestward projection of the Mesozoic suture zone into southern Idaho and Oregon. Interpretation of chemical and isotopic variations to be genetically related to tectonically juxtaposed lithospheric types depends critically on documenting a systematic geographic control of these variations. Examples of unsystematic, source-related variations with no interpretable geographic control have been reported by Carlson and others (1981) and Carlson (1984), where variable proportions of multiple components in Columbia River basalt magmas cannot be related to any current model of terrane boundaries.

$\mathrm{Nd}$ and Sr isotopic variations across the WISZ were reported for Mesozoic plutons in a study along the South Fork of the Clearwater River by Fleck (1990). Additional analyses (Table 3) and the SFCR data are plotted in Figure 2 against their distance from the WISZ. As expected from increased contributions from cratonal crust, $\mathrm{Sr}$ initial ${ }^{87} \mathrm{Sr} /{ }^{86} \mathrm{Sr}$ ratios $\left(\mathrm{Sr}_{\mathrm{i}}\right)$ become strikingly more radiogenic from west to east and $\mathrm{E}_{\mathrm{Nd}}(\mathrm{t})$ decreases abruptly. Isotopic results for plutons within $5 \mathrm{~km}$ of the suture exhibit the effects of components characteristic not only of the WSD terranes, but also of older, sub-continental source terranes (Fig. 2). Although the variations are clearly centered on the WISZ, isotopic ratios begin to show respective increases or decreases on either side of the zone well before the zone is reached. This influence on magmas by both terranes suggests that at least some of the plutons post-date actual accretion and that magmatism and tectonism continued after initial suturing. Samples most distant from the WISZ in either of the terranes have $\mathrm{E}_{\mathrm{Nd}}(\mathrm{t})$ and initial ${ }^{87} \mathrm{Sr} /{ }^{86} \mathrm{Sr}$ ratios, also calculated as $\mathrm{E}_{\mathrm{Sr}}(\mathrm{t})$, that are representative of the extremes of the two terranes. The covariation of the two radiogenic 


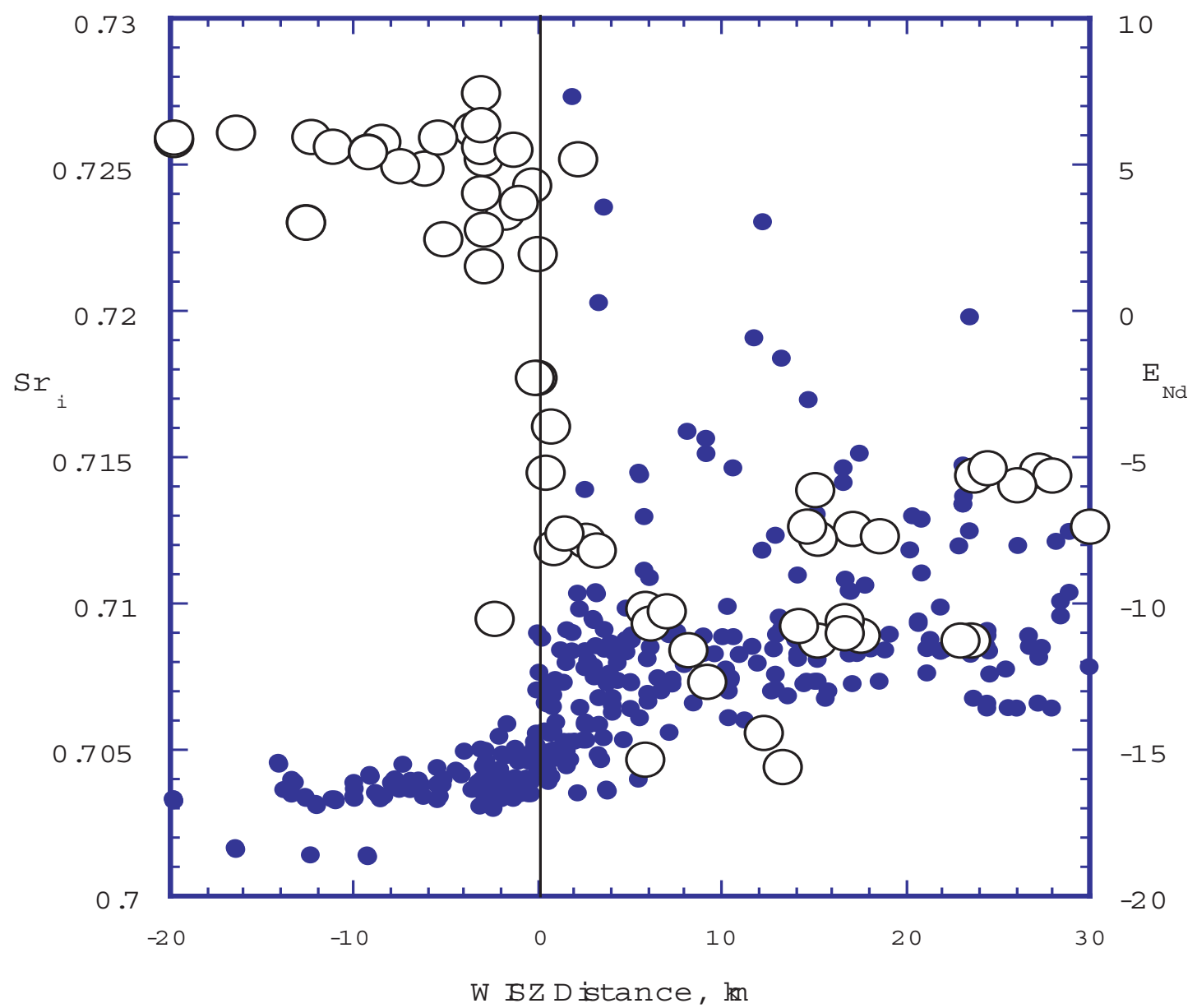

Figure 2. Variation diagrams of $\mathrm{ENd}(\mathrm{t})$ (open circles, right ordinate axis) and $\mathrm{Sr}_{\mathrm{i}}$ (solid circles, left ordinate axis) with distance eastward from the western Idaho suture zone (WISZ; vertical line). Plutons west of the WISZ intrude the accreted terranes; to the east wall rocks are referred to "cratonal" or Precambrian Belt/Yellowjacket terranes and may range in age from 1900 to 1300 Ma. Distances from the WISZ are shown as negative for WSD terranes to the west (or south) and positive for cratonal to the east (or north).

isotopes across the suture zone defines the inverse relation expected of a mixing process of oceanic-crustal or arc sources with Proterozoic lithospheric sources (Fig. 3). As discussed by Fleck (1990), multiple end-members are required to provide the observed chemical and isotopic variations, but the primary components represent the two crustal types sutured at the WISZ. Low $E_{N d}(t)$ samples indicate Proterozoic crustal sources with both upper- and lower-crustal affinities. Volcanic arc magma also represents a substantial component in suture-zone plutons of Cretaceous age (Fleck, 1990). 


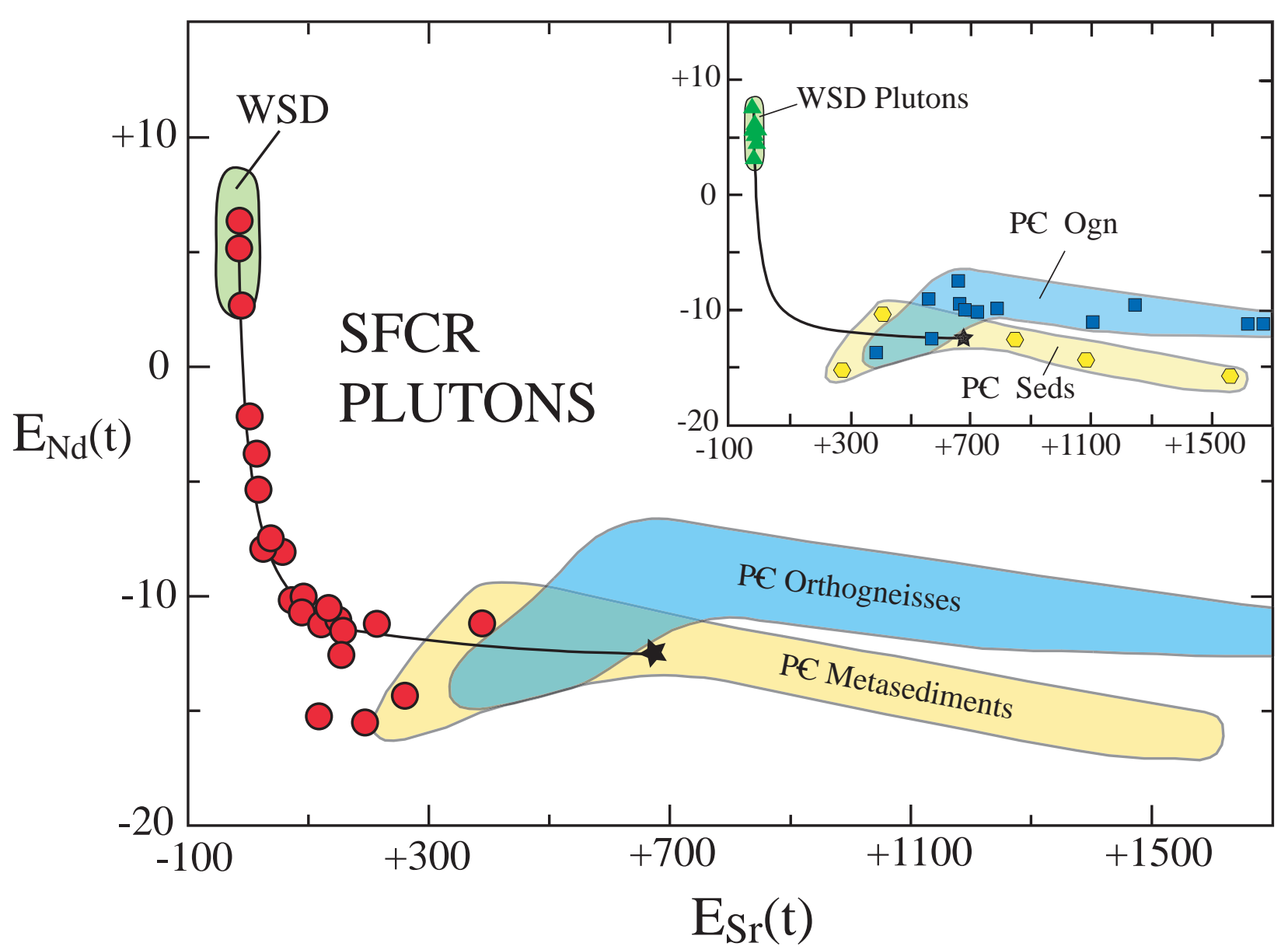

Figure 3. Variation of $E_{N d}(t)$ with $E_{S r}(t)$ in SFCR plutons (circles), WSD plutons (triangles), and samples of Precambrian orthogneisses (squares) and metasedimentary rocks (hexagons) at $80 \mathrm{Ma}$. A simple mixing model shown for mixtures of an arc magma $\left(E_{N d}=5.5, E_{S r}=-11\right)$ and a cratonal component $\left(E_{N d}=-12, E_{S r}=675\right)$ fits suture zone magmas with $E_{N d}>-10$ very well, but is not necessarily representative of available cratonal lithosphere. (From Fleck, 1990)

Trace-element variations in plutons across the WISZ reveal patterns consistent with mixing within suture zone magmas of components from substantially different sources. In addition to data reported here, results of Fleck (1990) and Manduca and others (1993) are used to illustrate the differences in magma chemistry of plutons emplaced within the different terranes and within the suture zone itself. Grouping data based on Sm/Nd and $E_{N d}(t)$, Fleck (1990) noted that plutons within $1 \mathrm{~km}$ west of the suture and $4 \mathrm{~km}$ to the east (Group 1) were isotopically and chemically distinct from those more distant from the zone. For this study samples of Manduca and others (1992; 1993) were grouped based on their map units. Their Little Goose Creek complex includes the most highly deformed rocks of the WISZ, with $\mathrm{Sr}_{\mathrm{i}}>0.704$. Most were included in Group 1, but their samples of Eastern porphyritic orthogneiss, with Rb contents greater than most Group 1 values, were located between 3.9 and $6 \mathrm{~km}$ east of the WISZ and were included with Group 2 rocks here. Rocks mapped as Hazard Creek complex (Manduca and others, 1992; 1993) have $\mathrm{Sr}_{\mathrm{i}}$ less than about 0.7045 , but many of the samples occur less than 3 $\mathrm{km}$ west of the suture and were included with Group 1. Nb versus Rb variations along the South Fork of the Clearwater River clearly distinguish suture-zone magmas from magmas of either the 
WSD and cratonal terranes (Fleck, 1990). Rb/Nb values west and east of the immediate area of the WISZ are characteristic of granites of volcanic arc and continental-collision origin (Pearce and others, 1984; Leeman and Hawksworth, 1986), respectively. Those east of the zone are more elevated as expected from emplacement through Proterozoic crust. Plutons within the WISZ, however, have Nb contents 3 to 8 times those of plutons within the accreted terranes (Fig. 4).

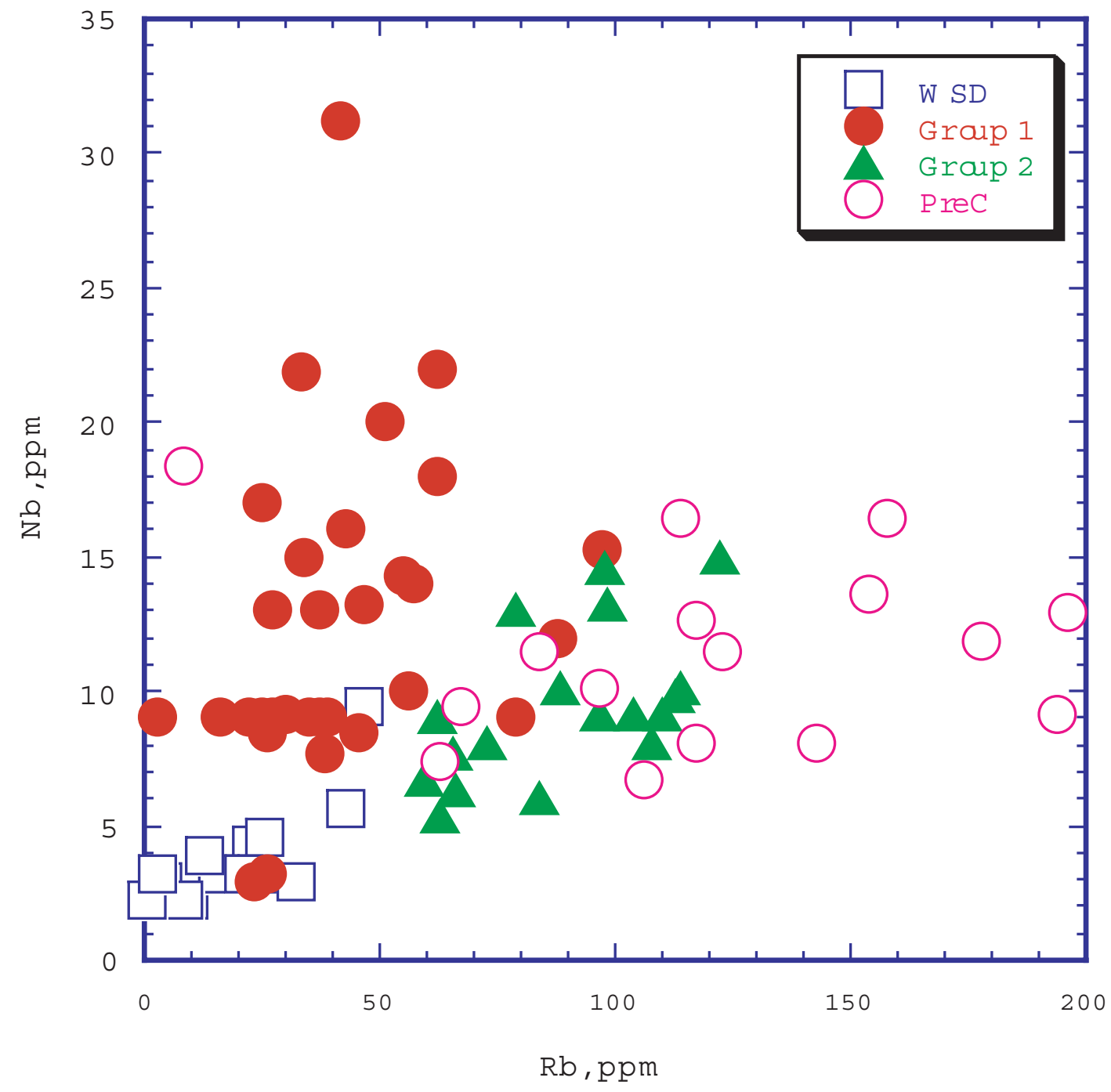

Figure 4. Variation diagram of $\mathrm{Nb}$ versus $\mathrm{Rb}$ in plutons of western Idaho. Symbols include: open squares, WSD plutons; solid circles, suture-zone plutons assigned to Group 1 by Fleck (1990); solid triangles, plutons east of the suture zone within cratonal or Precambrian terranes and corresponding to Groups 2 and 3 of Fleck (1990); open circles: Precambrian orthogneisses and schist. 
Results reported by Manduca and others (1993) show a similar pattern, with rocks of both the Hazard Creek and Little Goose Creek complexes north of McCall (Fig.1) being significantly higher in Nb than WSD plutons. Rb concentrations in plutonic rocks increase from west to east across western Idaho, but make an abrupt increase within $5 \mathrm{~km}$ east and west of the terrane boundary (Fig. 5). Like Nb concentrations, however, Sr values peak in plutons emplaced within the suture zone and decrease in both directions away from the boundary (Fig. 5).

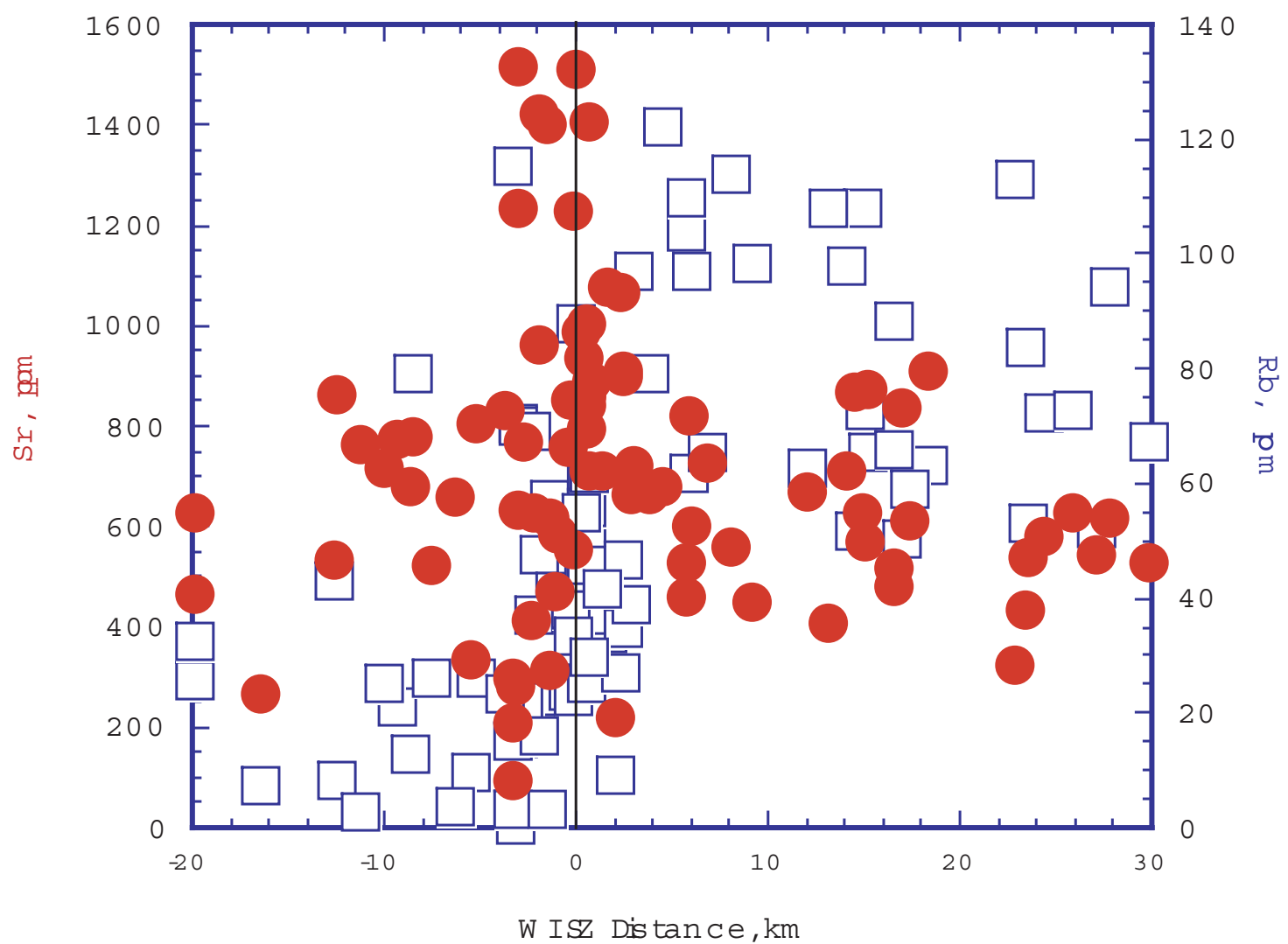

Figure 5. Variation diagram of $\mathrm{Rb}$ and $\mathrm{Sr}$ in plutons of western Idaho. $\mathrm{Rb}$ (open squares, right ordinate axis) and $\mathrm{Sr}$ (solid circles, left ordinate axis) are plotted against distance $(\mathrm{km})$ from the western Idaho suture zone (WISZ; vertical line). Distances are shown as negative for locations west (or south) of the suture within the WSD terranes. Rb concentrations increase abruptly crossing the WISZ from WSD terranes into cratonal terranes, whereas the highest and lowest Sr contents occur within $5 \mathrm{~km}$ on either side of this suture.

Interestingly, some of the lowest Sr values also occur in this area, near the eastern edge of WSD terranes. The low values appear to relate to high-silica, trondhjemitic plutons in the western margin of the WISZ, however. Sr concentrations also peak in plutons of the Hazard Creek and Little Goose Creek complexes (Manduca and others, 1993). High contents of sphene, epidote, 
and plagioclase in suture-zone plutons are consistent with elevated levels of these trace elements, but the distinctive enrichment of $\mathrm{Nb}$ and $\mathrm{Sr}$ in suture-zone magmas makes them unique.

Uniqueness of suture-zone magmas is defined further by variations in $\mathrm{Y}, \mathrm{Nd}$, and Sm when compared to each other and to elements discussed above. Normalized to Y concentrations, $\mathrm{Nb}$ concentrations define a clear maximum in Group 1 (suture-zone) plutons (Fig. 6).

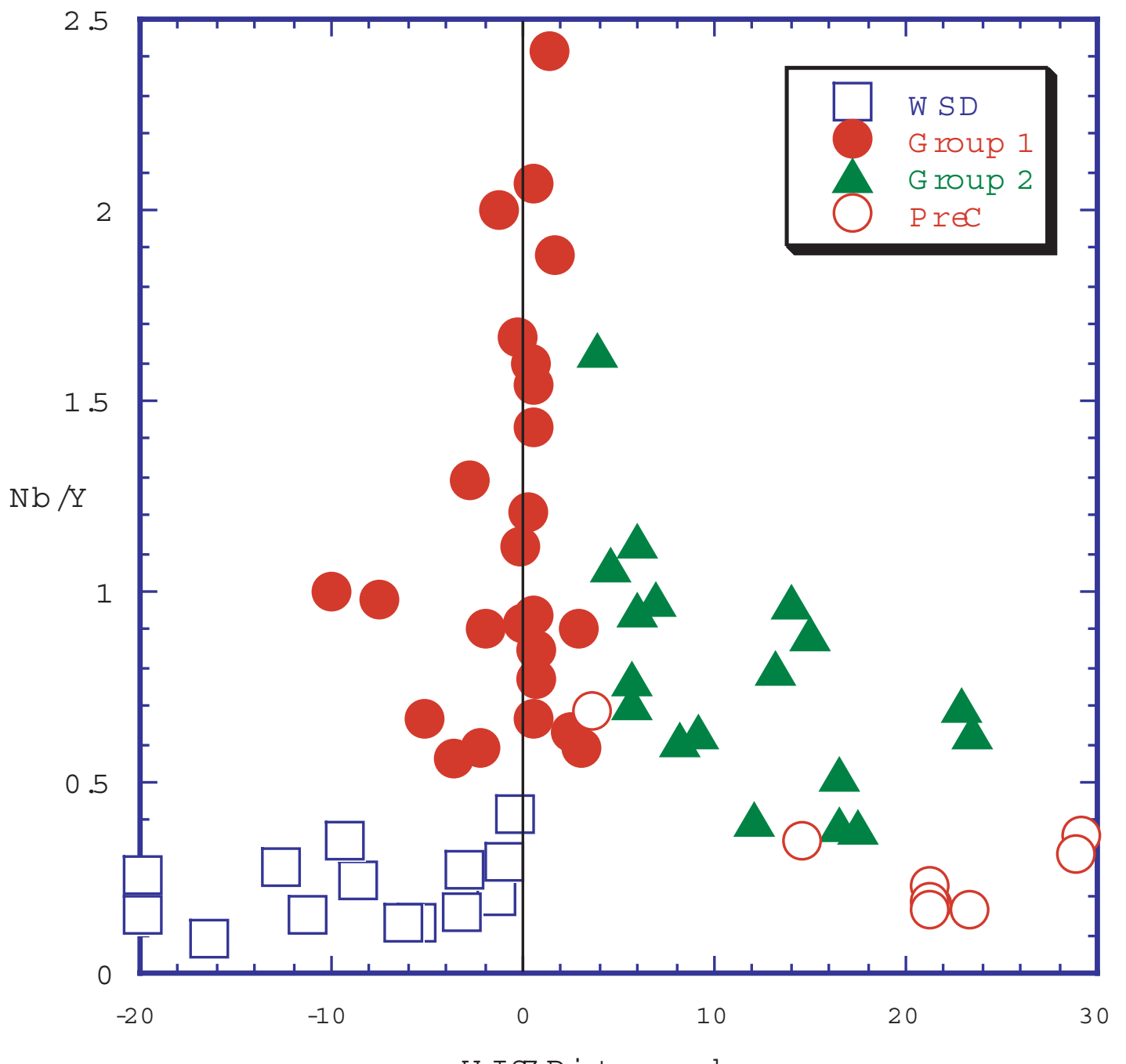

W ISZ D istance, $\mathrm{km}$

Figure 6. Variation diagram of $\mathrm{Nb} / \mathrm{Y}$ in plutons of western Idaho with distance eastward from the WISZ. The highest $\mathrm{Nb} / \mathrm{Y}$ ratios occur within about $5 \mathrm{~km}$ of the WISZ (vertical line) in Group 1 plutons (Fleck, 1990). Negative distances are west (or south) of the WISZ. Symbols are as in Figure 4. Comparison to Fig. 2 demonstrates that plutons most affected by mixing of components from the isotopically distinct WSD and cratonal sources are also the ones with the highest $\mathrm{Nb} / \mathrm{Y}$ ratios.

$\mathrm{Nb} / \mathrm{Y}$ values for the WSD suite form a generally constant band between about 0.1 and 0.5 (Fig. 6). Suture zone plutons, however, range from a low of 0.6 to greater than 2.4. (Some samples of Manduca and others (1993) with exceptionally low yttrium were omitted from this figure). $\mathrm{Nb} / \mathrm{Y}$ 
in plutons east of the WISZ decreases back toward values averaging about $0.7 . \mathrm{Nd} / \mathrm{Y}$ values also reflect significant increases in suture zone magmas due not only to increases in total REE, but also to greater light REE and yttrium fractionation within and east of the WISZ (Fig. 7).

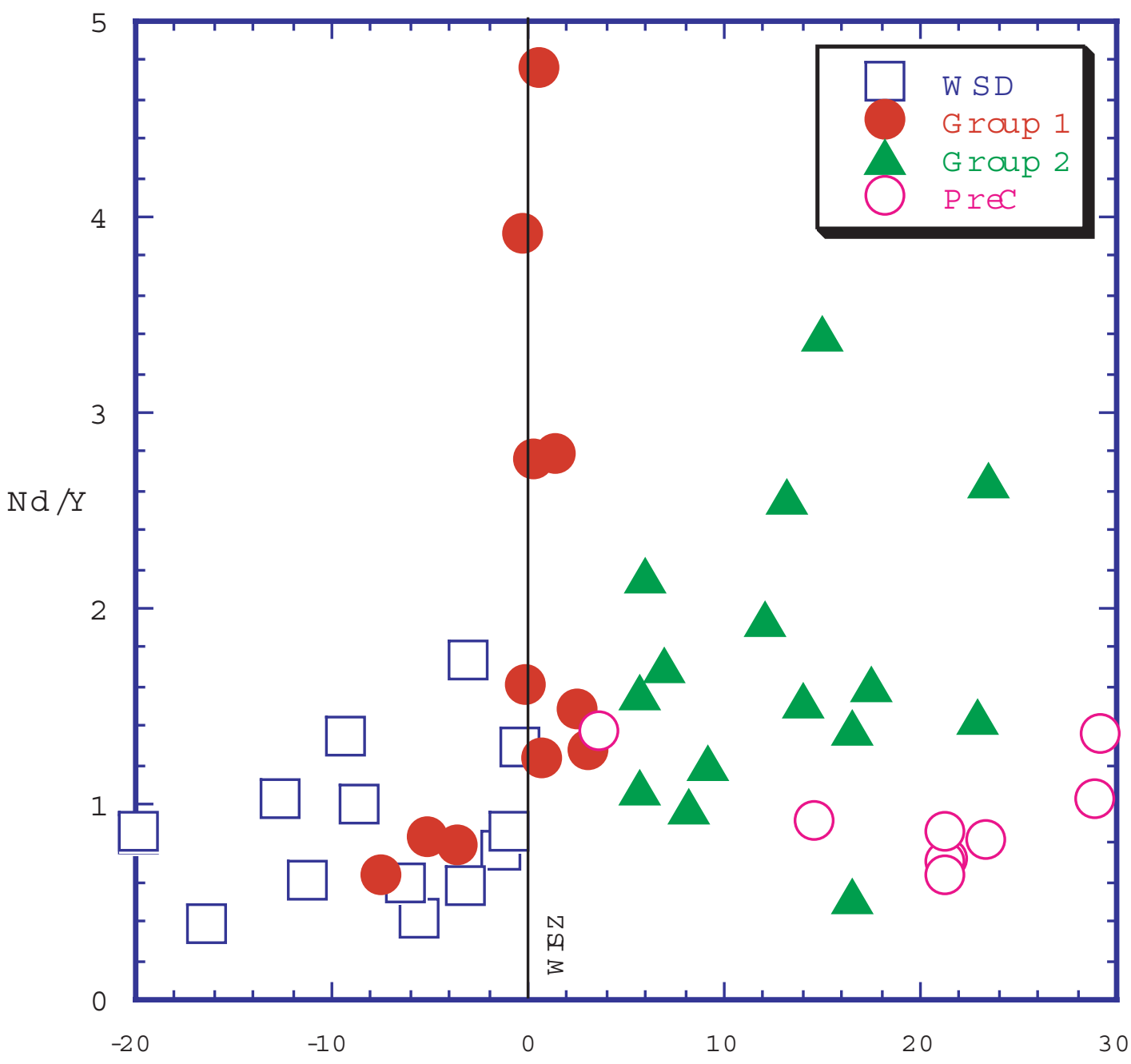

W ISZ Dis tance, $\mathrm{km}$

Figure 7. Variation diagram of $\mathrm{Nd} / \mathrm{Y}$ in plutons of western Idaho with distance eastward from the WISZ. As with $\mathrm{Nb} / \mathrm{Y}$, the highest $\mathrm{Nd} / \mathrm{Y}$ ratios occur near the WISZ (vertical line). Negative distances are west (or south) of the WISZ. Symbols are as in Figure 4.

An Nd peak is observed, but is only defined by a few samples. These and other distance versus isotopic or trace-element variations such as $\mathrm{Sm} / \mathrm{Y}, \mathrm{Sr} / \mathrm{Sm}$, and $\mathrm{Sr} / \mathrm{Nd}$ not only aid in locating the true crustal boundary between the WSD and cratonal terranes, but also constrain the nature of source materials and petrogenetic processes in plutons emplaced within the WISZ (Fleck, 1990). Increases in $\mathrm{Nb}, \mathrm{Rb}, \mathrm{Sr}$, and ${ }^{87} \mathrm{Sr} /{ }^{86} \mathrm{Sr}$ in plutons emplaced near the suture within the WSD 
terranes supports other evidence that accretion of this crust occurred prior to the $110 \pm 5 \mathrm{Ma}$ age obtained by Manduca and others (1993) for a pluton of the Little Goose Creek complex.

\section{LOCATION OF THE WESTERN IDAHO SUTURE ZONE}

The geochemical indicators mentioned above provide excellent tools for delineating the western Idaho suture zone (WISZ). Most importantly, extensive measurements (over 625 samples) of initial ${ }^{87} \mathrm{Sr} /{ }^{86} \mathrm{Sr}$ ratios $\left(\mathrm{Sr}_{\mathrm{i}}\right)$ reported by Armstrong et al. (1977), Fleck and Criss (1985), Criss and Fleck (1987), Manduca and others (1992), and the present study define this boundary (Fig. 1) in a way that is consistent with geologic mapping of segments of the zone (Myers, 1982; Hoover, 1986; Onash, 1987; Bonnichsen, 1987; Lund and Snee, 1988; Manduca and others, 1992; Lund, 1995). Much additional mapping is needed to establish the boundary between supracrustal rocks from the different terranes. As available mapping reveals, however, much of the suture has been replaced by post-collisional plutonic rocks and the isotopic variation may well represent the best approximation of its original position. In all figures and discussions distances to or from the WISZ are measured to the best estimate line shown in figures 1 and 8, which is based on available topographic, structural, petrologic, isotopic, and chemical data. We accept that the location can only be approximate, partially because the suture is a zone of substantial width rather than a line, but also because our hundreds of isotopic results pale in the face of a $300 \mathrm{~km}$ structure.

Location of the WISZ at its north-westernmost extent is controlled by samples in eastern Washington at Granite Point, 20 miles NW of Clarkston and along Cummings Creek, some 27 miles WSW of Clarkston (Fig. 8). Eastward in Idaho, the suture must pass north of Lewiston, Spaulding, and Peck, and south of Genesee, Juliaetta, and Teakean, trending approximately E-W. Exposures of the highly sheared zone several hundred meters north of Dworshak Dam and fault slivers of high $\mathrm{Sr}_{\mathrm{i}}(>0.706)$ granitic gneiss pinpoint the suture along Merrys Bay and crossing Orofino Creek near its confluence with Cedar Creek. In the area of Weippe, Idaho, the WISZ makes a clockwise bend of about $110^{\circ}$ probably passing 2 to 3 miles northeast of that town, but is concealed by flows of Columbia River basalt. The suture trends slightly west of south, crossing the main Clearwater River near the confluence with Suttler Creek, but appears to be complicated in this area by tectonic slivers or a thrust duplex of WSD rocks east of Suttler Creek. Continuing southward, the WISZ passes about 2 miles east of Harpster. Data along the South Fork of the Clearwater River (SFCR) were discussed above, placing the axis of the zone along Browns Creek and Mill Creek and trending south-southwest along Little Slate Creek. The WISZ crosses the Salmon River at Partridge Creek and trends almost due south from there along the east flanks of Patrick Butte and Granite Mountain. As shown in Figure 8, the zone continues south along the east flank of No Business Mountain, where it follows the plagioclase-quartzbiotite gneiss unit of Bonnichsen (1987), and south along the west side of West Mountain. In this area the suture zone apparently was reactivated by post-Columbia River basalt normal faults, which mimic its trend southward along the east side of Indian Mountain. South of Indian Mountain rocks of the WSD terranes are not well exposed and the WISZ is at least partially covered by flows of Columbia River basalt. Long, linear, north-trending valleys, such as Squaw Creek, follow the well-developed foliation in medium- to high-grade schist that parallels the WISZ, but these topographic features may also be due to reactivation during Tertiary normal faulting. The WISZ is located west of the alignment of Squaw Creek in the area of Ola, Idaho, where it is hidden beneath Tertiary and Quaternary cover after being traceable for over $300 \mathrm{~km}$. 


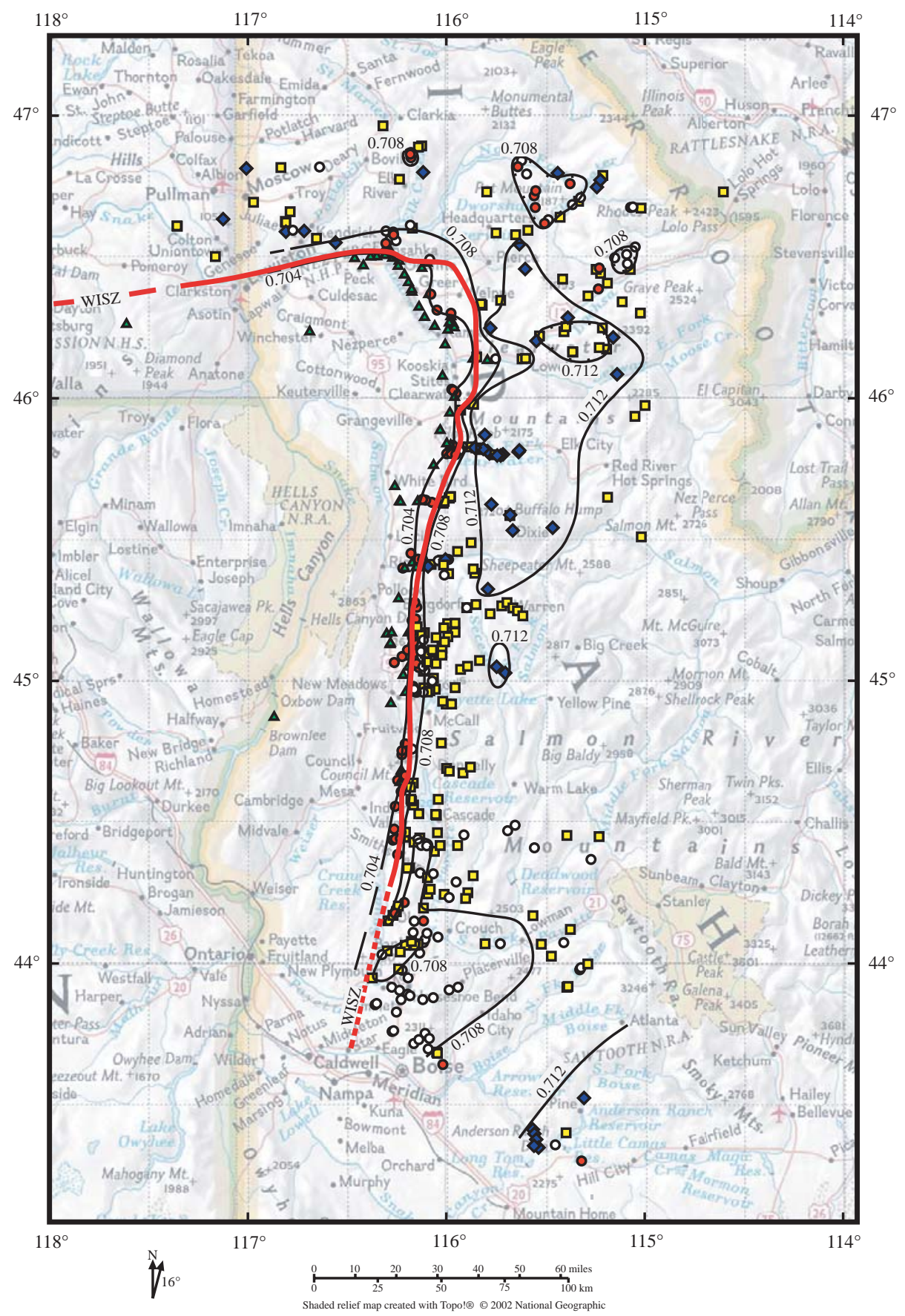

Figure 8. Map showing the distribution of initial ${ }^{87} \mathrm{Sr} /{ }^{86} \mathrm{Sr}$ ratios $\left(\mathrm{Sr}_{\mathrm{i}}\right)$ of Mesozoic and Tertiary plutonic rocks in western Idaho and easternmost Oregon. Sr isopleths are shown for initial ratios of 0.704 , 0.708 , and 0.712 . Symbols for samples indicate ${ }^{87} \mathrm{Sr} /{ }^{86} \mathrm{Sr}$ ratios calculated for ages shown in Table 1. The heavy line shows the approximate location of the western Idaho suture zone (WISZ) that forms the boundary between the oceanic Wallowa-Seven Devils (WSD) terranes and Precambrian cratonal terranes of North America. The zone of strongly deformed metamorphic and igneous rocks commonly occurs between the 0.704 and $0.708 \mathrm{Sr}$ isopleths. The limited area represented by samples between these isopleths documents the steep isotopic gradient across this crustal boundary. 


\section{AGE PATTERNS AND CHRONOLOGY OF THE WISZ}

With a few exceptions, most age determinations in western Idaho have utilized the K-Ar or ${ }^{40} \mathrm{Ar} /{ }^{39} \mathrm{Ar}$ techniques. The current study is no exception, adding to the already large data set produced by McDowell and Kulp (1969), Armstrong (1974, 1975, 1976), Armstrong and others (1977), Criss and others (1982), Fleck and Criss (1985), Criss and Fleck (1987), Lewis and others (1987); Lund and Snee (1988), and Snee and others (1995). Previously, we suggested limiting ages for terrane juxtaposition and consolidation of 130 to $75 \mathrm{Ma}$, with a preferred period between 95 and 80 Ma (Fleck and Criss, 1985; Criss and Fleck, 1987). Lund and Snee (1988) suggested late Early Cretaceous and early Late Cretaceous accretion confined to a 25 Ma period between 118 and $93 \mathrm{Ma}$, but suggest that movement took place along other parts of the WISZ until 79 Ma. Results of zircon U-Pb and garnet Sm-Nd geochronology (Manduca and others, 1993; Getty and others, 1993) are consistent with our broader range, but show that initial suturing occurred at about $130 \mathrm{Ma}$. Evidence that movements took place along the WISZ until at least $80 \mathrm{Ma}$, however, remains unaffected by these results.

$\mathrm{U}-\mathrm{Pb}$ zircon, Rb-Sr, K-Ar, and ${ }^{40} \mathrm{Ar} /{ }^{39} \mathrm{Ar}$ ages of intrusive rocks of the WSD terranes document a history of Permian to Early Cretaceous plutonism (Armstrong, 1975, 1976; Armstrong and others, 1977; Ave Lallemant and others, 1980; Criss and Fleck, 1987; Walker, 1995). Although some were reduced somewhat by regional metamorphic events, near the WISZ $\mathrm{K}-\mathrm{Ar}$, and ${ }^{40} \mathrm{Ar} /{ }^{39} \mathrm{Ar}$ ages decrease abruptly to Late Cretaceous ages over a distance of $10 \mathrm{~km}$ or less near and within the WISZ (Fig. 9; Tables 3 and 4). North and east of the WISZ apparent ages continue to decrease slowly in the cratonal or Precambrian terrane toward the central parts of the Idaho batholith (Armstrong, 1974, 1975, 1976; Criss and others, 1982; Fleck and Criss, 1985; Criss and Fleck, 1987; Lund and Snee, 1988; Snee and others, 1995). Ages for hornblende range from about 82 to $74 \mathrm{Ma}$ in plutons within 25 to $30 \mathrm{~km}$ east of the WISZ in the Atlanta lobe of the Idaho batholith (Criss and Fleck, 1987). Similar plutons within the western part of the Bitterroot lobe are farther east and ages are lower, ranging from 65 to $55 \mathrm{Ma}$ (Criss and Fleck, 1987). Despite this apparent eastward migration of magmatism, Ar age patterns in western Idaho are characterized by a "step function", nearly coincident with the WISZ (Fig. 9).

To evaluate the relationship between the WISZ and the general age pattern documented in figure 9 , a series of age-versus-distance plots were constructed approximately normal to the trend of the suture, using sufficient length along strike to obtain sufficient age data. Eight age profiles across the WISZ from west of Orofino, Idaho on the north to the area of Cascade, Idaho near the southern extent of exposures are shown in Figs. 10 through 18. Profiles were constructed by measuring the perpendicular distance of each sample from the WISZ and grouping them by location along the suture. This procedure is equivalent to projecting the data to the centerline of each group. Centerlines of the profiles are shown on Figure 1. Where data are available, profile lengths are from $20 \mathrm{~km}$ west to $30 \mathrm{~km}$ east of the suture and incorporate data over a width of 25 to $38 \mathrm{~km}$ along the suture. Profiles are named for a major location within the area represented.

\section{OROFINO}

Compilation of $\mathrm{K}-\mathrm{Ar}$ and ${ }^{40} \mathrm{Ar} /{ }^{39} \mathrm{Ar}$ ages from the E-W-trending portion of the WISZ center about the area of Orofino, Idaho. An age versus distance profile (Fig. 10) reveals a steep decrease in both biotite and hornblende ages between 1 and $5 \mathrm{~km}$ west of the suture. The profile defines an age minimum coinciding with the strongly foliated zone of the WISZ. Ages within the WSD terranes (negative distances) are variable and probably reflect real age differences in the plutons, as discussed by Criss and Fleck (1987). Ages of 75 to $70 \mathrm{Ma}$ for hornblende in the WSD terrane and within the suture zone east of Orofino are consistent with emplacement of Late 


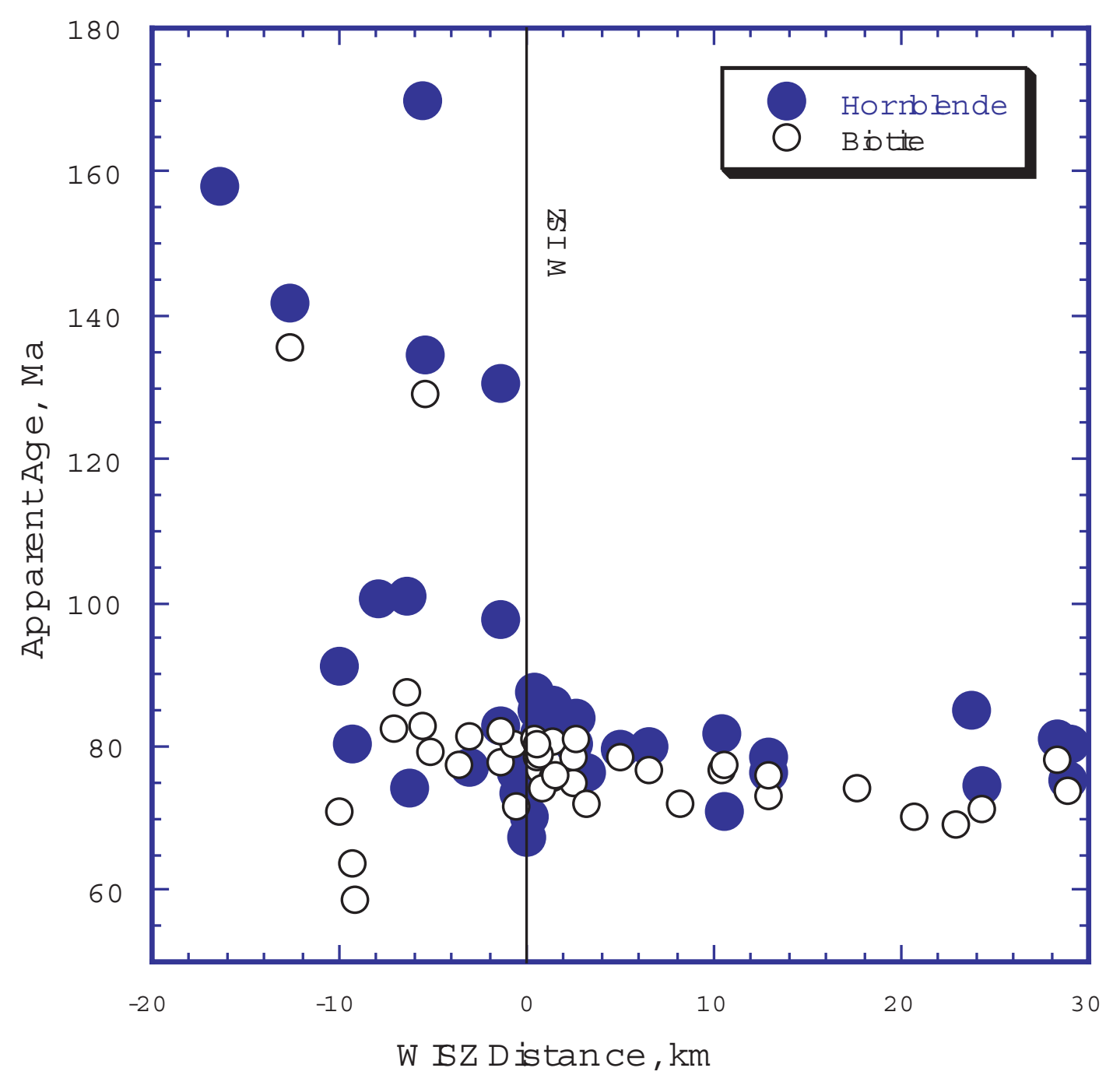

Figure 9. Variation diagram of $\mathrm{K}-\mathrm{Ar}$ and ${ }^{40} \mathrm{Ar} /{ }^{39} \mathrm{Ar}$ ages on hornblende (solid circles), biotite (open squares) and muscovite (open triangles) from plutonic rocks in western Idaho. Negative distances are west (or south) of the WISZ. Note that biotite ages decrease abruptly between 6 and $10 \mathrm{~km}$ west (south) of the WISZ, whereas hornblende ages generally exhibit this decrease much closer to the zone. We suggest that this effect is related to greater thermally induced $\mathrm{Ar}$ loss from biotite in WSD plutons caused by the precipitous rise of cratonal terranes and along the WISZ and syntectonic emplacement of suture-zone plutons. We interpret the presence of biotite and muscovite ages less than about $65 \mathrm{Ma}$ on both sides of the suture zone as indicating young, probably post-deformational, plutonism, especially in the Kamiah-Weippe-Pierce area. Hornblende ages appear to be less affected by these younger events.

Cretaceous or Early Tertiary intrusions across the suture zone and into WSD terranes. Isotopic data demonstrate, however, that these plutons, such as along the main canyon of the Clearwater southeast of Orofino, are derived primarily from sources within the accreted lithosphere. Early Tertiary plutons are documented near Elk River to the north and to the east of Lowell along the 
Lochsa River (Criss and Fleck, 1987). The latest Jurassic to Early Cretaceous pluton at Peck, Idaho with a $\mathrm{Sr}_{\mathrm{i}}$ of 0.7034 yields biotite and hornblende ages of 129 and $135 \mathrm{Ma}$ (Fig. 10), respectively, indicating only minimal discordance at a distance of $6 \mathrm{~km}$ south of the WISZ. North of the suture, Armstrong and others (1977) report K-Ar ages of 83 and 73 Ma from hornblende and biotite, respectively, in a quartz diorite, whereas ages within the zone are as low as 74 and $71 \mathrm{Ma}$, respectively. Both age and age discordance of hornblende and biotite decrease toward the suture zone, suggesting that either the youngest intrusive rocks were emplaced along it or that recrystallization or shear heating due to deformation and uplift produced argon loss in the affected rocks. Defined on the basis of the ages observed, thermal and tectonic events within the WISZ in the Orofino area ceased in the 75 to 70 Ma period.

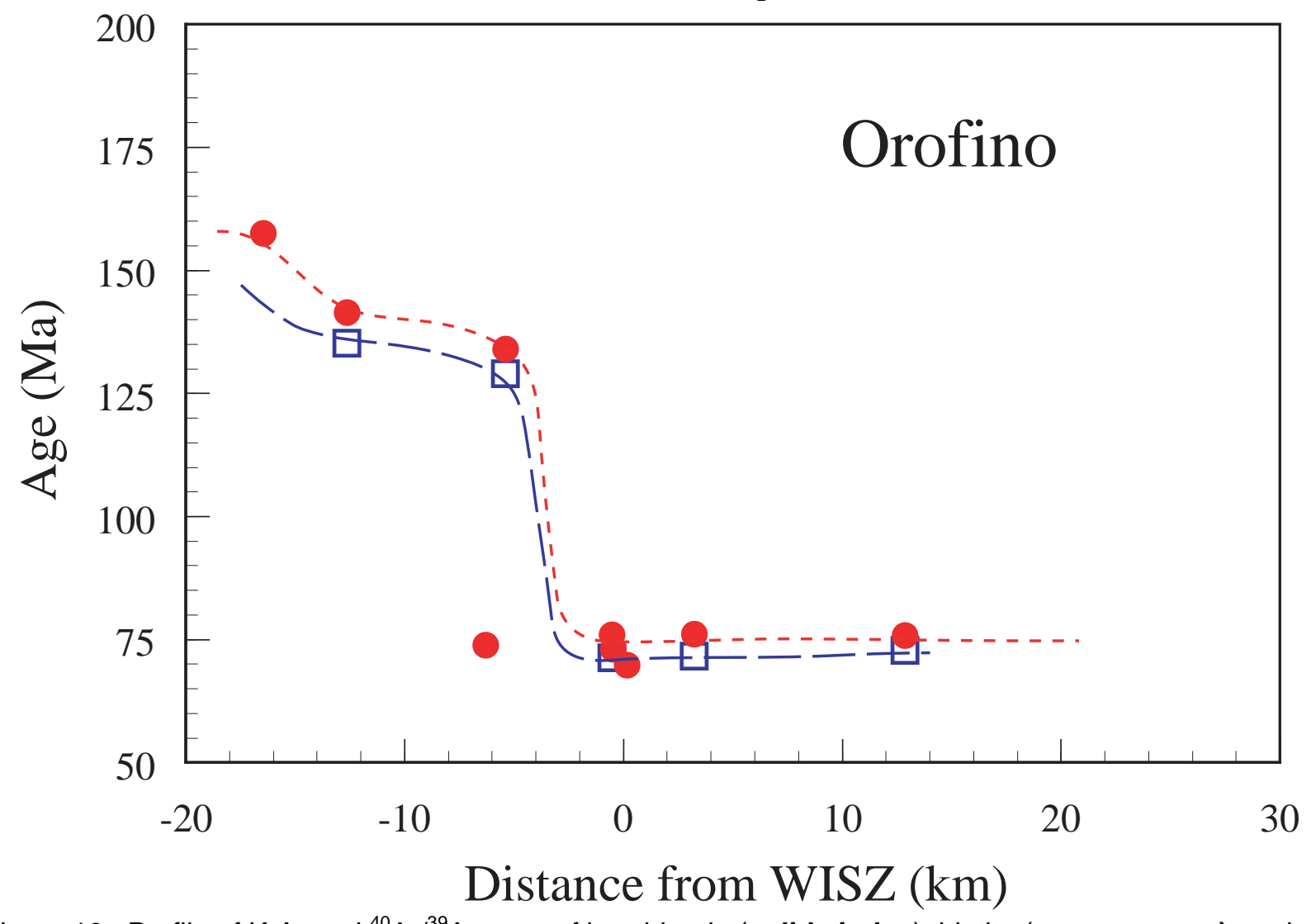

Figure 10. Profile of $\mathrm{K}-\mathrm{Ar}$ and ${ }^{40} \mathrm{Ar} /{ }^{39} \mathrm{Ar}$ ages of hornblende (solid circles), biotite (open squares), and muscovite (open triangles) from plutonic rocks centered approximately on Orofino, Idaho (Fig 1). The profile trends north-south across the WISZ from the accreted terranes on the south to the Precambrian terranes on the north. Distance is given in kilometers with negative distances shown to the south of the WISZ.

\section{WEIPPE}

The axis of an approximately $110^{\circ}$ bend in the WISZ is located inexactly in the area northeast of Weippe, Idaho (Fig. 8), where the zone is concealed by flows of Columbia River basalt. As at Orofino, ages near the WISZ show the effects of Late Cretaceous and Early Tertiary plutons characterized by muscovite ages as young as 63 Ma for sample 837-25C. Minimum ages of biotite in both terranes near the WISZ, however, are less than $60 \mathrm{Ma}$, whereas hornblende ages decrease abruptly from over $140 \mathrm{Ma}$ to 65 to $62 \mathrm{Ma}$ about $12 \mathrm{~km}$ west of the projected location of the zone (Fig. 11). 


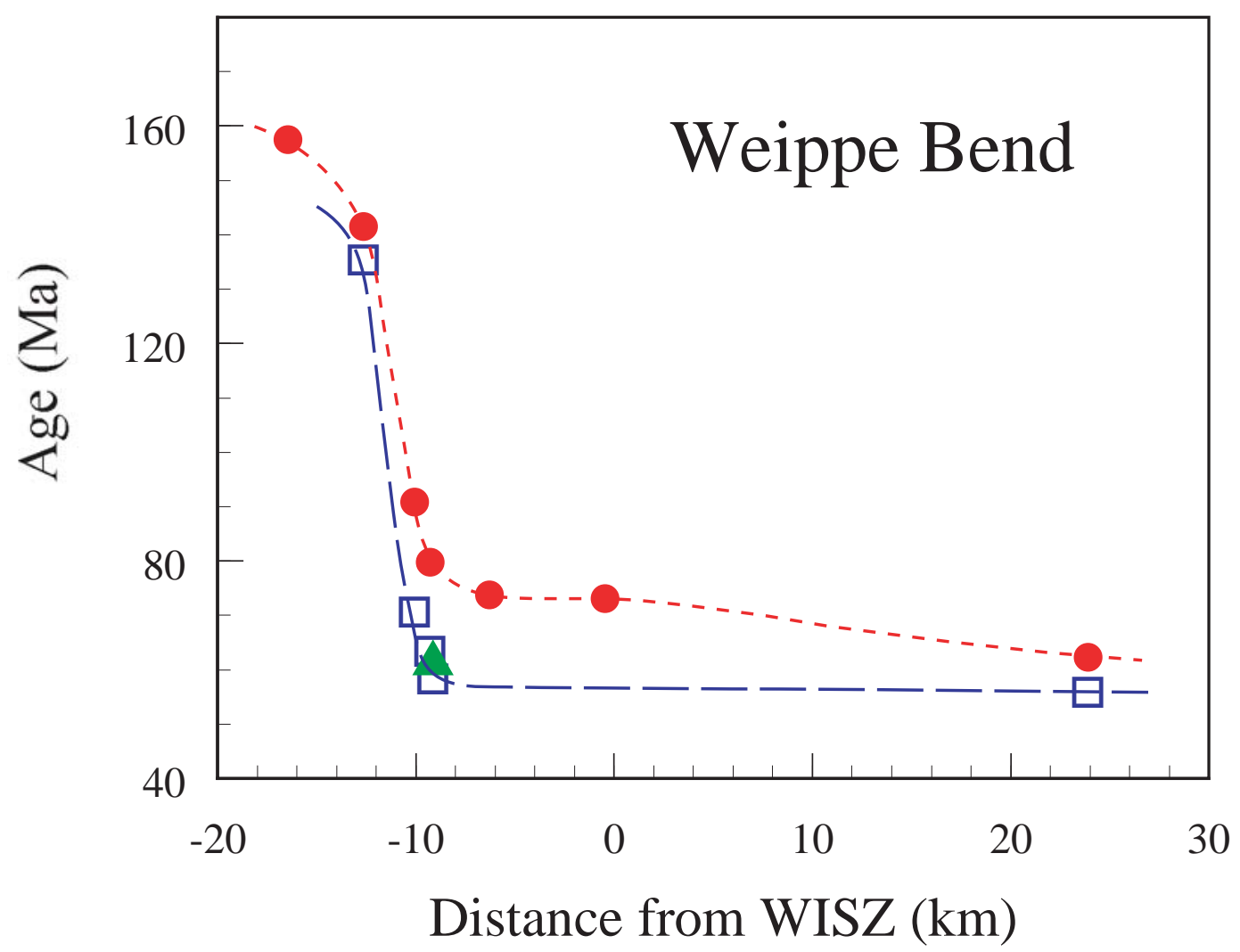

Figure 11 Profile of $\mathrm{K}-\mathrm{Ar}$ and ${ }^{40} \mathrm{Ar} /{ }^{39} \mathrm{Ar}$ ages of plutonic rocks trending southwest to northeast approximately through Weippe, Idaho (Fig 1). Distance is given in kilometers with negative distances shown to the southwest of the WISZ. Symbols are as in Fig. 10.

Because the WISZ is only approximately located in this area, an interpretation placing its position 5 to $10 \mathrm{~km}$ farther southwest would be consistent with the age pattern, but isotopic constraints indicate that plutons in that area represent WSD-type magmas. In either case, however, the decrease in age across the zone follows the general pattern discussed by Criss and Fleck (1987), with Early Cretaceous and older rocks becoming highly discordant adjacent to the WISZ and reflecting thermal disturbance. Plutons intruding the Precambrian terrane north and east of Weippe reflect the age pattern of the western part of the Bitterroot lobe of the Idaho batholith with hornblende ages of 66 to $62 \mathrm{Ma}$. These values were considered representative of one of the early Tertiary plutonic episodes in the Bitterroot lobe of the Idaho batholith by Criss and Fleck (1987). They reported ${ }^{40} \mathrm{Ar} /{ }^{39} \mathrm{Ar}$ age plateaus and abrupt steps in the hornblende age/distance profiles that also occur in that region. Age data in the Weippe area indicate thermal and/or tectonic disturbance of argon systems in WSD rocks between 80 and $62 \mathrm{Ma}$, with plutons of the 66 to 62 Ma episode emplaced near or across the zone subsequent to the major deformation within the WISZ.

\section{KOOSKIA}

The geographic distribution of argon ages across the WISZ where it crosses the Clearwater River just east of Kooskia, Idaho (Fig. 12) reveals a classic pattern of thermal-loss, such as that described by Hart (1964) (Fig. 13). The greatest age discordance occurs 2 to $3 \mathrm{~km}$ west of the suture, where biotite ages are over 50 Ma younger than coexisting hornblende, but slightly older than ages on hornblende $7 \mathrm{~km}$ east of the zone. The steep decrease in biotite ages occurs about 
$12 \mathrm{~km}$ west of the suture, but some hornblende analyses still yield Early Cretaceous ages only 2 $\mathrm{km}$ from the suture. Farther west in the WSD terrane the two minerals are nearly concordant at about $140 \mathrm{Ma}$, reflecting rapid cooling and minimal thermal disturbance. Ages more than $8 \mathrm{~km}$ west of the suture zone in this profile are the same as shown in the Weippe profile because of the abrupt bend in the WISZ near Weippe, ID. This overlap of the Kooskia profile with the northeast-trending Weippe profile in the area west of the suture (Fig. 1) exaggerates the width of suture-zone effects and complicates the pattern of hornblende ages. East of the WISZ, younger plutonism of the Bitterroot lobe of the Idaho batholith (Criss and Fleck, 1987) strongly affects biotite ages, but coexisting hornblende yields ages up to $74 \mathrm{Ma}$, similar to ages for highly deformed rocks within the suture zone near Orofino.

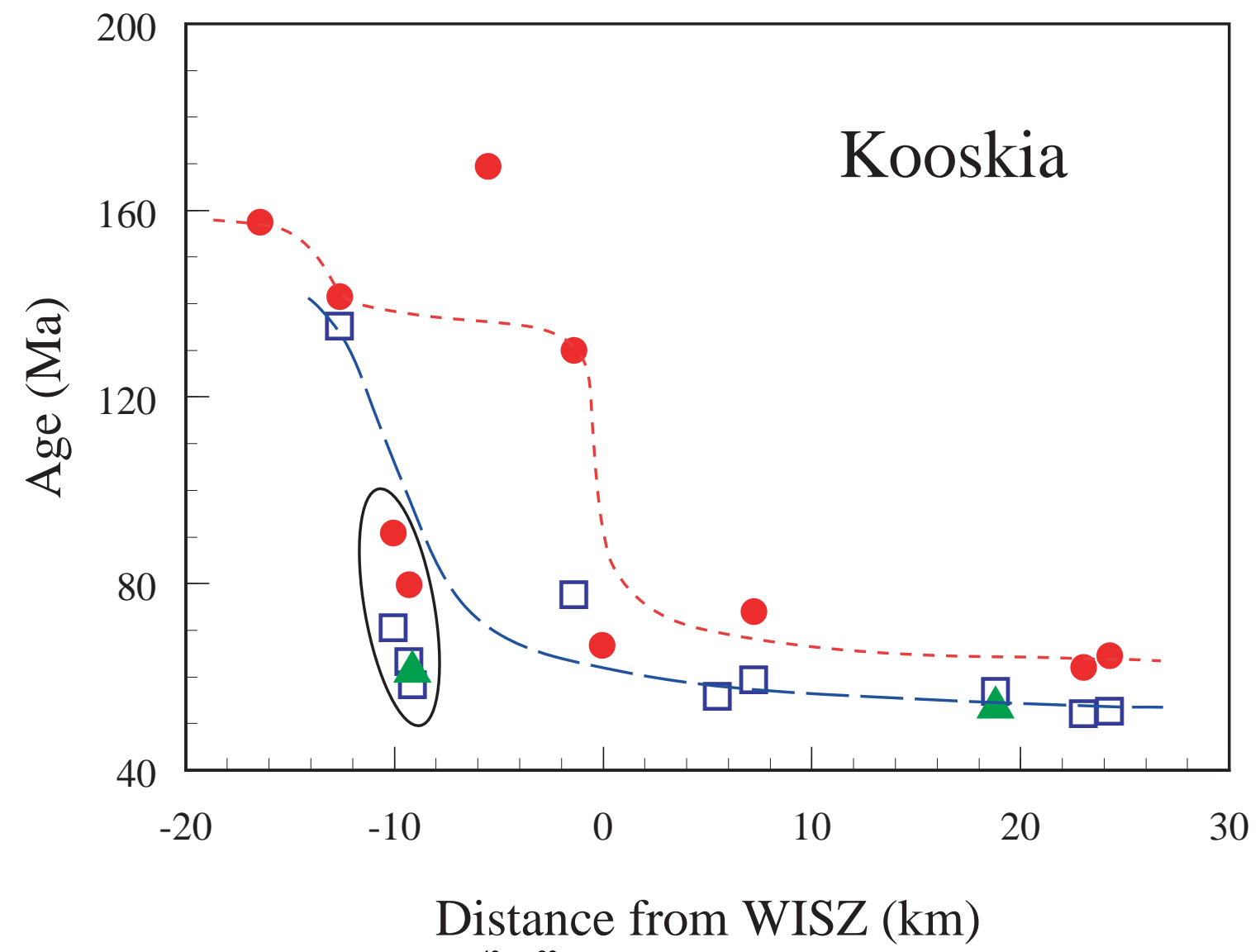

Figure 12. West-east profile of $\mathrm{K}-\mathrm{Ar}$ and ${ }^{40} \mathrm{Ar} /{ }^{39} \mathrm{Ar}$ ages of plutonic rocks centered approximately on Kooskia, Idaho (Fig 1), where the WISZ crosses the Clearwater River at a high angle. Distance is given in kilometers with negative distances shown to the west of the WISZ. Ages enclosed in an ellipse near $10 \mathrm{~km}$ west of the WISZ reflect effects of younger, Bitterroot-lobe plutonism and are not considered related to timing of WISZ deformation. Symbols are as in Fig. 10.

These results suggest that plutons immediately east of the suture, many of which are also highly deformed, were emplaced during and cooled shortly after the last major tectonism in the zone. Suture zone deformation may be as young as 78 to 74 Ma in the Kooskia area. 


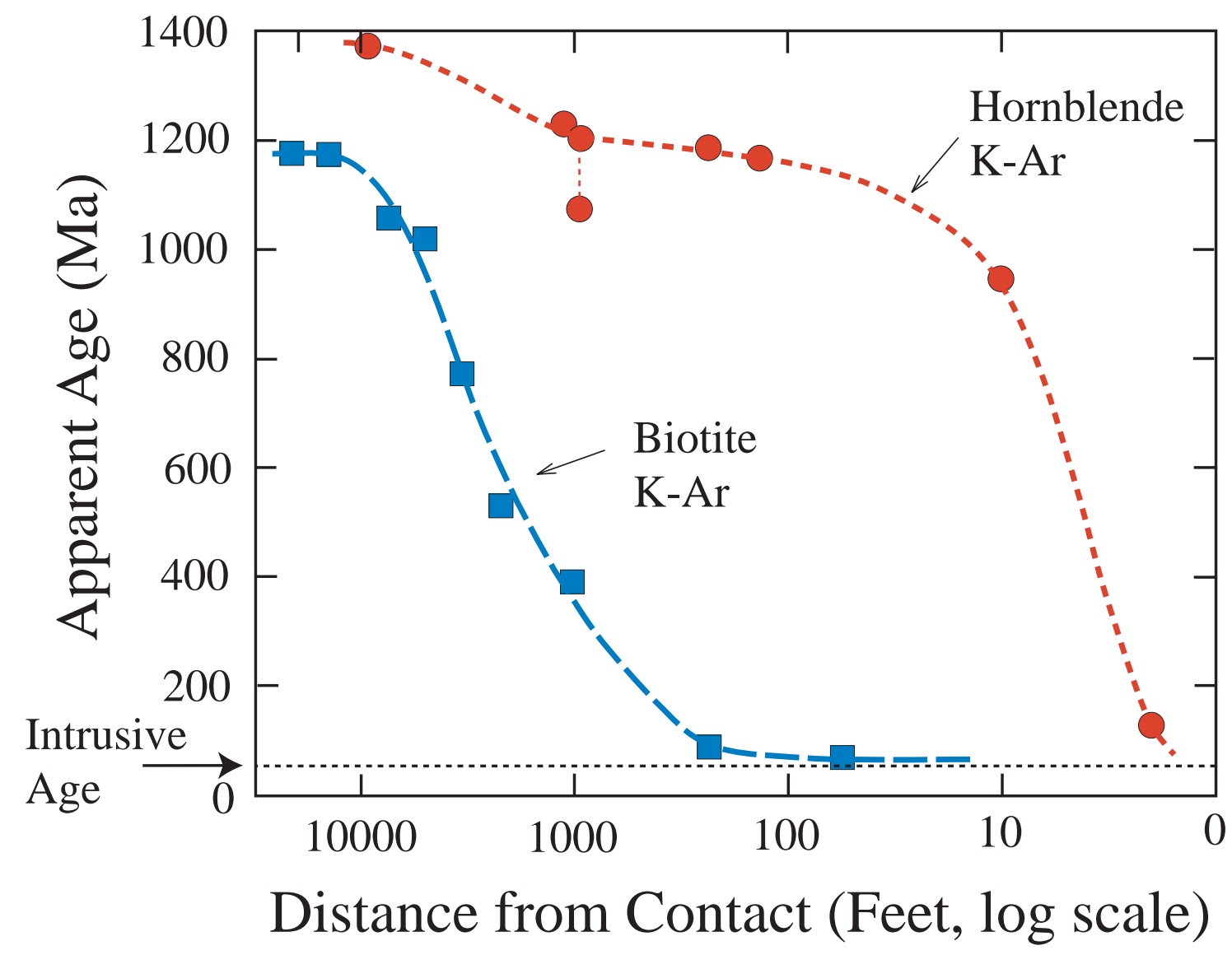

Figure 13. Classic pattern of decrease in K-Ar apparent ages of biotite and hornblende in $>1300 \mathrm{Ma}$ schists and gneiss is shown as samples approach the contact with a 54 Ma pluton. (Figure is modified from Hart, 1964. Distance scale is reversed for comparison to western Idaho). Note that the greatest age discordance occurs at distances where hornblende ages (short dashes) begin to decrease sharply, whereas biotite ages (long dashes) are already near the age of the disturbing event (between 250 feet and 50 feet from the contact in this example). As shown in Fig. 9, this point would be between about 2 and 8 kilometers west (or south) of the WISZ in western Idaho, where hornblende ages approach the true age of the 170- to 140-Ma WSD plutons, but biotite ages reflect the Late Cretaceous thermal and tectonic events associated with the WISZ.

\section{SOUTH FORK CLEARWATER RIVER (SFCR)}

As noted above, studies along the South Fork of the Clearwater River have been the basis for characterizing geochemical trends across the WISZ (Fleck and Criss, 1985; Fleck, 1990). Age patterns are also well documented along the SFCR, but the age/distance trends of the WSD terranes are less well defined due to cover of the Jurassic and Early Cretaceous plutons by flows of Columbia River basalt west of the suture. Late Cretaceous plutons dominate both terranes and concordant or nearly concordant ages on biotite and muscovite decrease smoothly from about 87 Ma west of the WISZ to about 70 Ma $22 \mathrm{~km}$ east of it (Fig. 14). Highly deformed granodiorite $(807-28 \mathrm{H})$ in the suture zone at Mill Creek yields a Rb-Sr muscovite and whole-rock age of 85.7 $\mathrm{Ma}$, indicating cooling below about $500^{\circ} \pm 50^{\circ} \mathrm{C}$ (Jäger and others, 1967; Hunziker and others, 1992). This muscovite yields a K-Ar age of $76.7 \mathrm{Ma}$, however, concordant with coexisting biotite, indicating $9 \mathrm{~m}$.y. for this cooling. Hornblende, with a closure temperature of about 
$530^{\circ} \pm 40^{\circ} \mathrm{C}$ (Harrison, 1981), from a tonalite $700 \mathrm{~m}$ away yields a ${ }^{40} \mathrm{Ar} /{ }^{39} \mathrm{Ar}$ incremental-heating plateau age of $80.8 \pm 0.4 \mathrm{Ma}$ (Criss and Fleck, 1987), whereas coexisting biotite is $75.8 \mathrm{Ma}$, indicating $5 \mathrm{~m} . \mathrm{y}$. for this cooling. The indicated difference in cooling rates for adjacent plutons and the concordance of the micas suggests that the mica ages are the result of deformation, completed at about 76-77 Ma. Biotite-muscovite age differences increase with distance to the east of these suture zone rocks, indicating slower uplift rates away from the WISZ, similar to those observed in the central part of the Idaho batholith (Criss and Fleck, 1987).

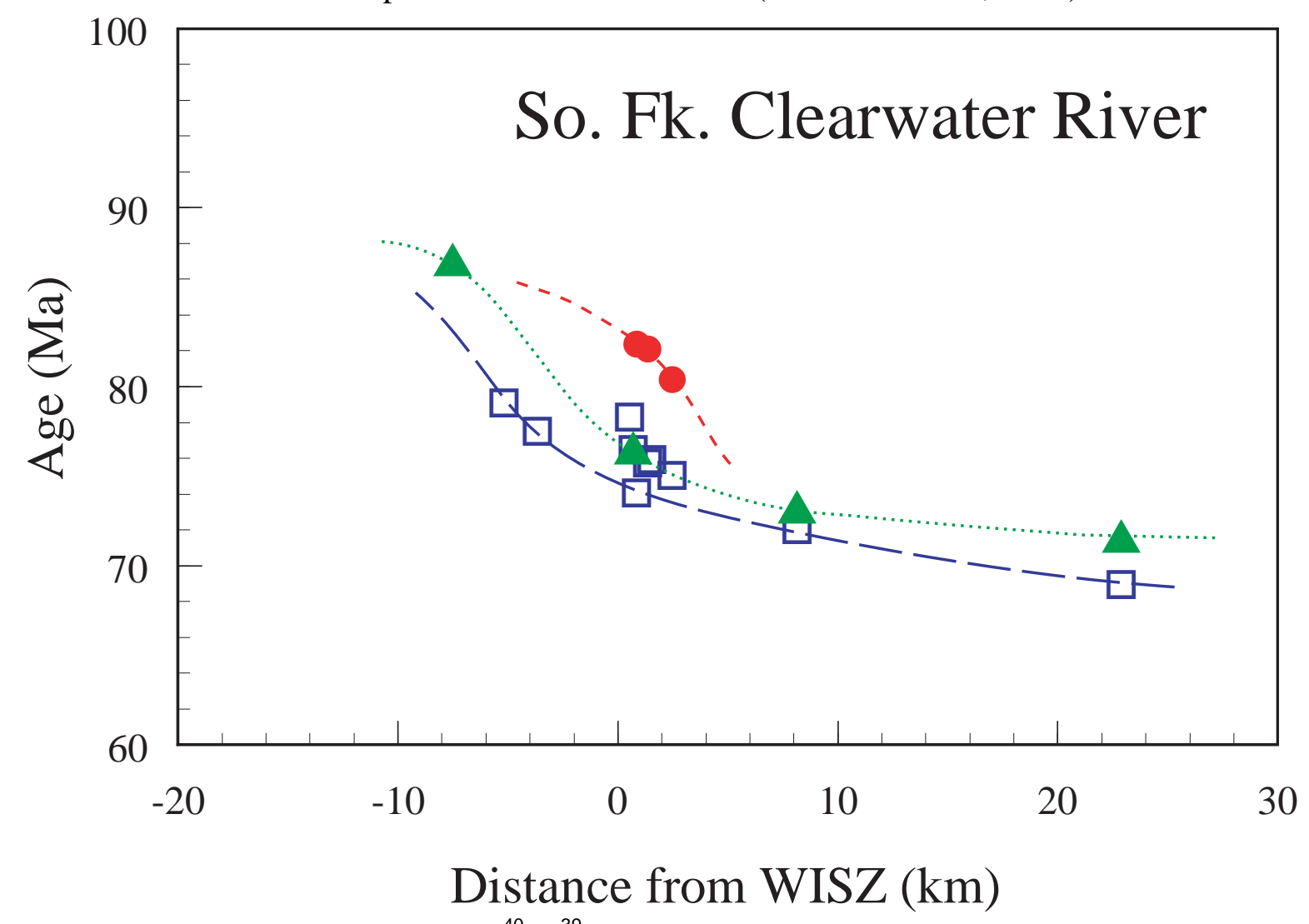

Figure 14. West-east profile of $\mathrm{K}-\mathrm{Ar}$ and ${ }^{40} \mathrm{Ar} /{ }^{39} \mathrm{Ar}$ ages of plutonic rocks centered approximately on the South Fork of the Clearwater River (SFCR), Idaho (Fig 1). Distance is given in kilometers with negative distances shown to the west of the WISZ. Symbols are as in Fig. 10.

\section{SLATE CREEK}

The Ar age profile for the Slate Creek area (Fig. 15) suffers from the absence of plutonic rocks to establish ages within the WSD terranes. Lund and Snee (1988) and Snee and others (1995) report apparent ages of about 109 Ma for hornblende from metamorphosed supracrustal rocks of the Riggins Group 12 to $15 \mathrm{~km}$ west of the suture, decreasing to 95 to 90 Ma near the zone. These data have not been included in the profile, which has been restricted to plutonic rocks. A small, highly deformed pluton $2 \mathrm{~km}$ west of the suture yields reversely discordant biotite and hornblende ages at about $80 \mathrm{Ma}$, however, significantly less than reported for the supracrustal metamorphic rocks. Without better control of depth relationships between these samples, we cannot compare their ages in the same profile. We can conclude that the rocks in and near the WISZ in this area reached closure temperatures and were not significantly affected by deformation after about 84 to $80 \mathrm{Ma}$. Suturing clearly occurred well before that time and deep-seated, mildly deformed, epidote-bearing tonalite was emplaced $2 \mathrm{~km}$ east of the suture at 
about 84 Ma (Lund and Snee, 1988). This unit also yields a biotite age of 82 Ma (Criss and Fleck,1987), documenting the rapid cooling of the body. These ages support a model of rapid vertical uplift such as discussed by Lund and Snee (1988).

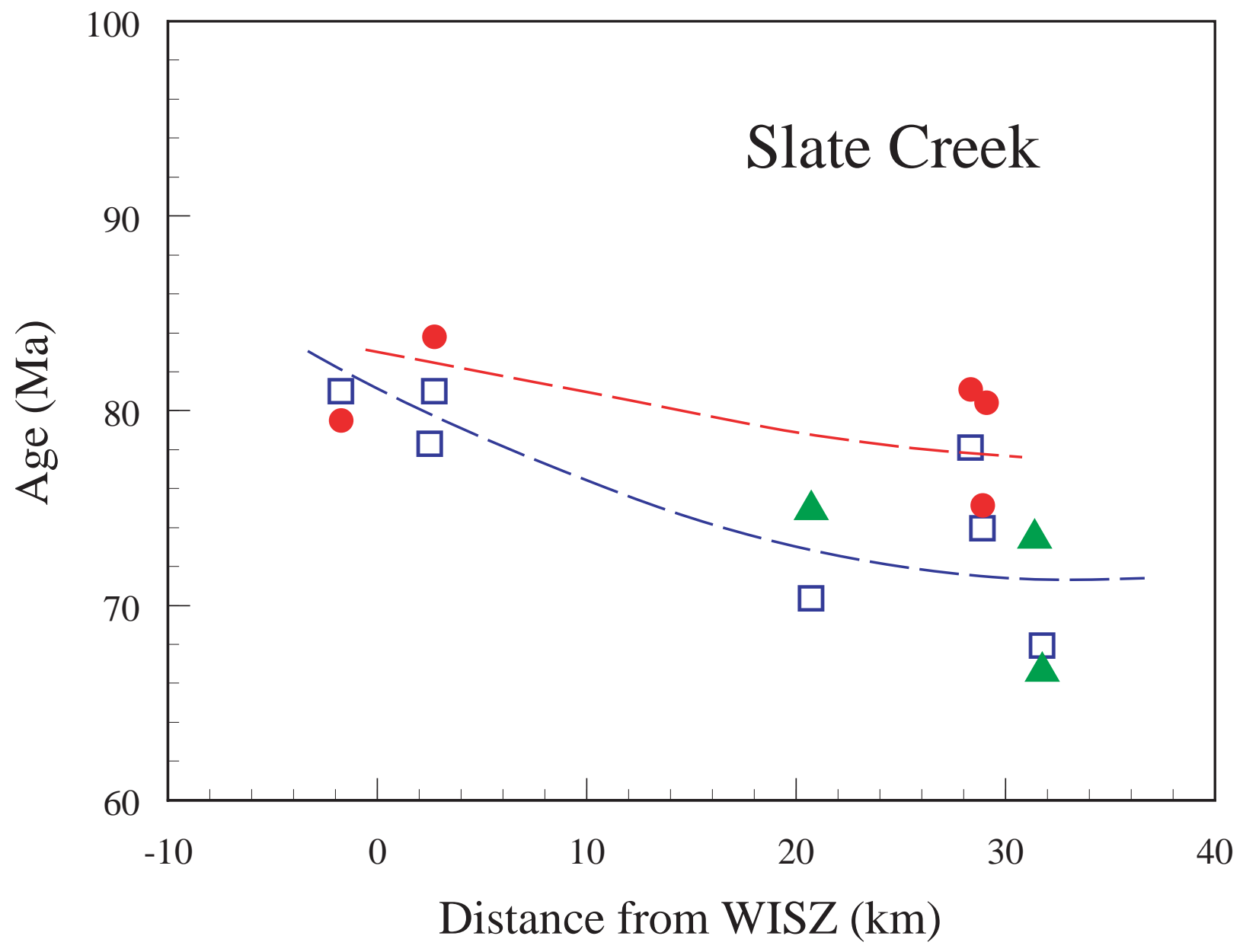

Figure 15. West-east profile centered approximately on Slate Creek (Fig 1), where it crosses the WISZ at nearly a right angle. Distance is given in kilometers with negative distances shown to the west of the WISZ. Symbols are as in Fig. 10.

\section{SALMON RIVER}

As in the Slate Creek profile, no early plutons of the WSD terranes were revealed by Ar geochronology of rocks along the Salmon River. Results of K-Ar and ${ }^{40} \mathrm{Ar} /{ }^{39} \mathrm{Ar}$ studies along the Salmon River east of Riggins, Idaho reveal sub-parallel biotite and hornblende age/distance variations within the Precambrian terrane and extending westward into the WSD terranes (Fig. 16). Hornblende apparent ages average 4 to 5 Ma older than coexisting biotite with muscovite equal to or slightly less than biotite. The approximately linear west to east decrease in mica ages 


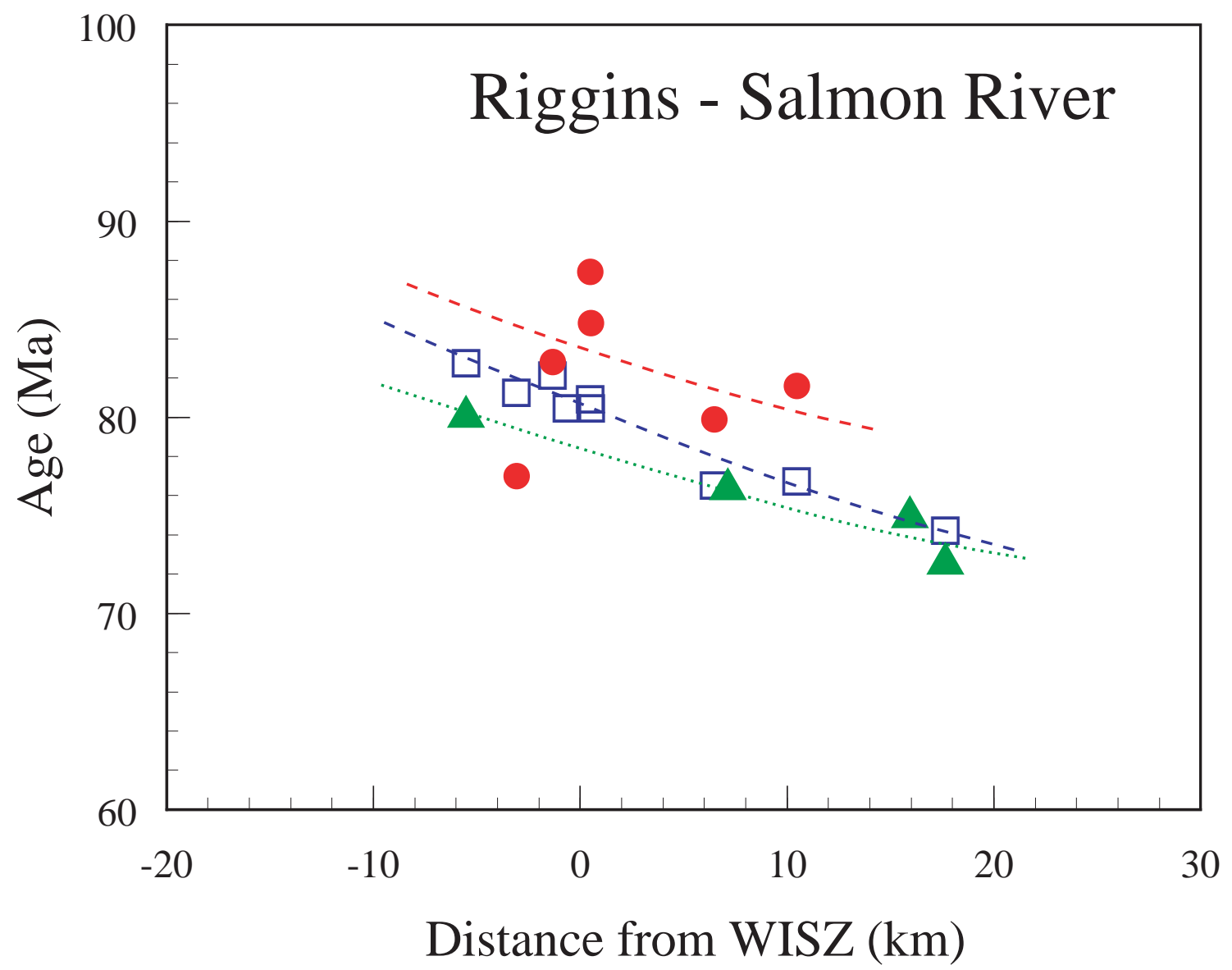

Figure 16. West-east profile centered approximately on the Salmon River at Riggins, Idaho (Fig 1). Distance is given in kilometers with negative distances shown to the west of the WISZ. Symbols are as in Fig. 10.

suggests up-on-the-east tilting, although this could occur as small sequential vertical uplifts as suggested by Lund and Snee (1988, Fig. 11). Suture zone plutons, generally strongly foliated and planar bodies, were probably emplaced prior to about $85 \mathrm{Ma}$, based on hornblende from deformed tonalites within the suture zone, but disturbed ${ }^{40} \mathrm{Ar} /{ }^{39} \mathrm{Ar}$ incremental-heating spectra indicate modest amounts of excess Ar may be present in some of these minerals. Accepting an age of $85 \mathrm{Ma}$ for the deformed plutons cooling below about $500^{\circ} \mathrm{C}$, major deformation probably ceased between 80 and $85 \mathrm{Ma}$.

\section{GRANITE MOUNTAIN}

Presence of older plutons in the Granite Mountain area, located about $25 \mathrm{~km}$ northwest of Mc Call, Idaho, defines a typical pattern of argon loss. Studied by Manduca and others (1992, 1993), the Hazard Creek complex represents early post-suturing emplacement of magmas along the WISZ. Manduca and others (1993) report a U-Pb zircon age of 118 Ma for this unit, which yields Ar ages of about $100 \mathrm{Ma}$ on hornblende, but only 82 to $88 \mathrm{Ma}$ on coexisting biotite. The age profile (Fig. 17) has the characteristic sigmoidal pattern expected from Ar loss from phases with different closure temperatures (Fig. 13; Hart, 1964). The steep decrease in the hornblende ages occurs between 1 and $2 \mathrm{~km}$ west of the suture, whereas that for biotite is not well defined, but must occur more than $8 \mathrm{~km}$ west of the zone. This defines an approximately 18 to $20 \mathrm{Ma}$ discordance immediately west of the suture zone. 


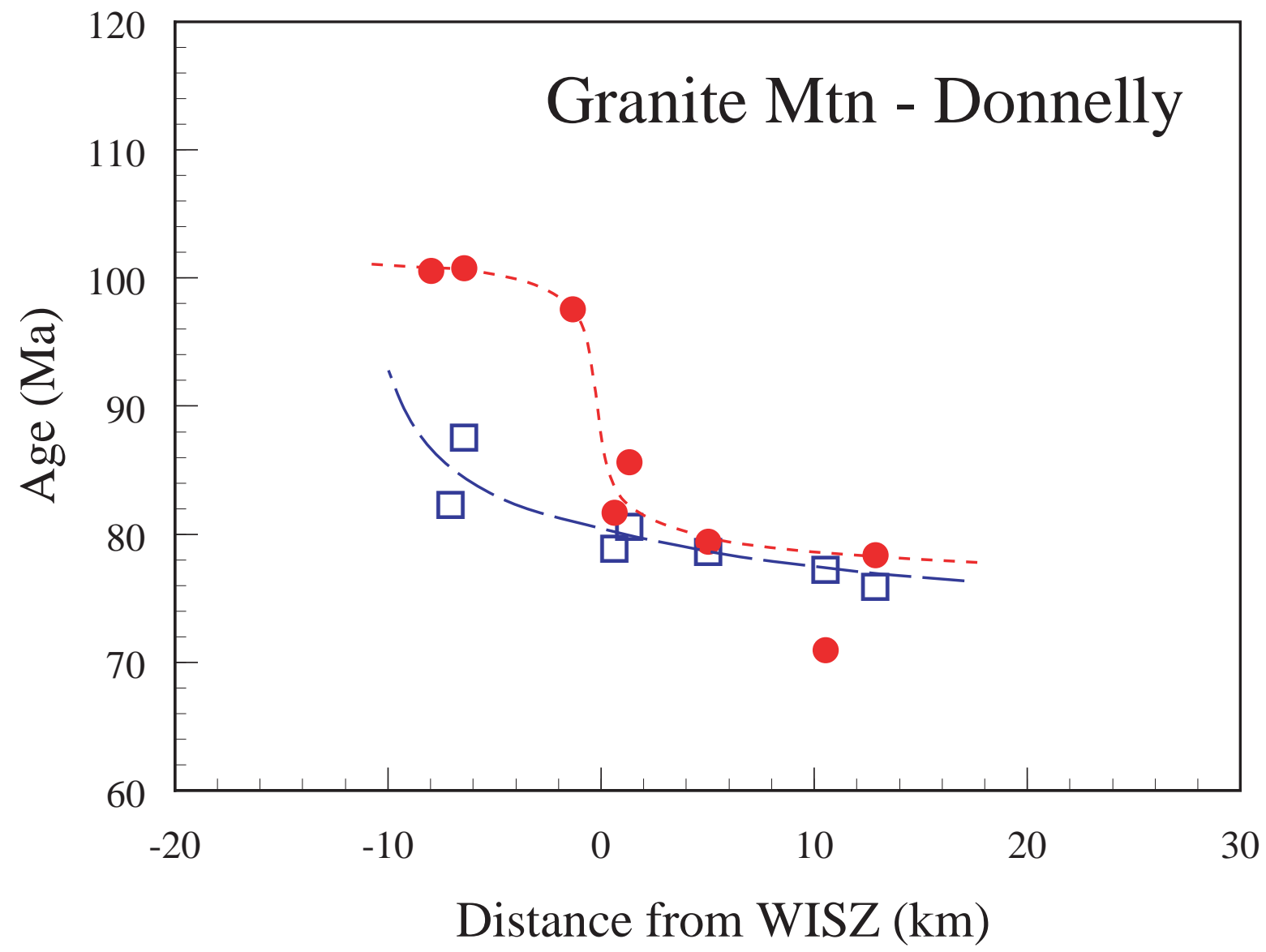

Figure 17. West-east profile centered approximately on Granite Mountain, east of Donnelly and north of McCall, Idaho (Fig 1). Distance is given in kilometers with negative distances shown to the west of the WISZ. Symbols are as in Fig. 10.

Ages east of the suture zone continue to decline, not unlike that expected from tilting or closelyspaced block uplift. However, concordant or nearly concordant mineral-pairs raise the possibility of eastward migrating intrusion, with progressively younger plutons emplaced within and east of the suture zone. A U-Pb age of about $90 \mathrm{Ma}$ is reported by Manduca and others (1993) for these rocks, indicating a discordance of about 10 Ma with hornblende. A discordance of this magnitude compared to the near concordance for Ar ages favors a progressive uplift over any model of migrating multiple intrusion. Apparent ages within the suture zone are consistent with cessation of deformation in the 85 to 80 Ma period similar to results to the north along the Salmon River.

\section{CASCADE}

The age profile across the WISZ in the area of Cascade, Idaho is the southernmost for which sufficient data are available (Fig. 18). Results of Armstrong (1975) and Tables 3 and 4 reflect significant argon loss from biotite $6 \mathrm{~km}$ west of the suture. Hornblende ages may also be affected, but no other age control is available. Compared to the $118 \mathrm{Ma} \mathrm{U}-\mathrm{Pb}$ zircon age reported by Manduca and others (1993) for the Hazard Creek complex, however, the 120 Ma KAr age for hornblende is quite consistent. 


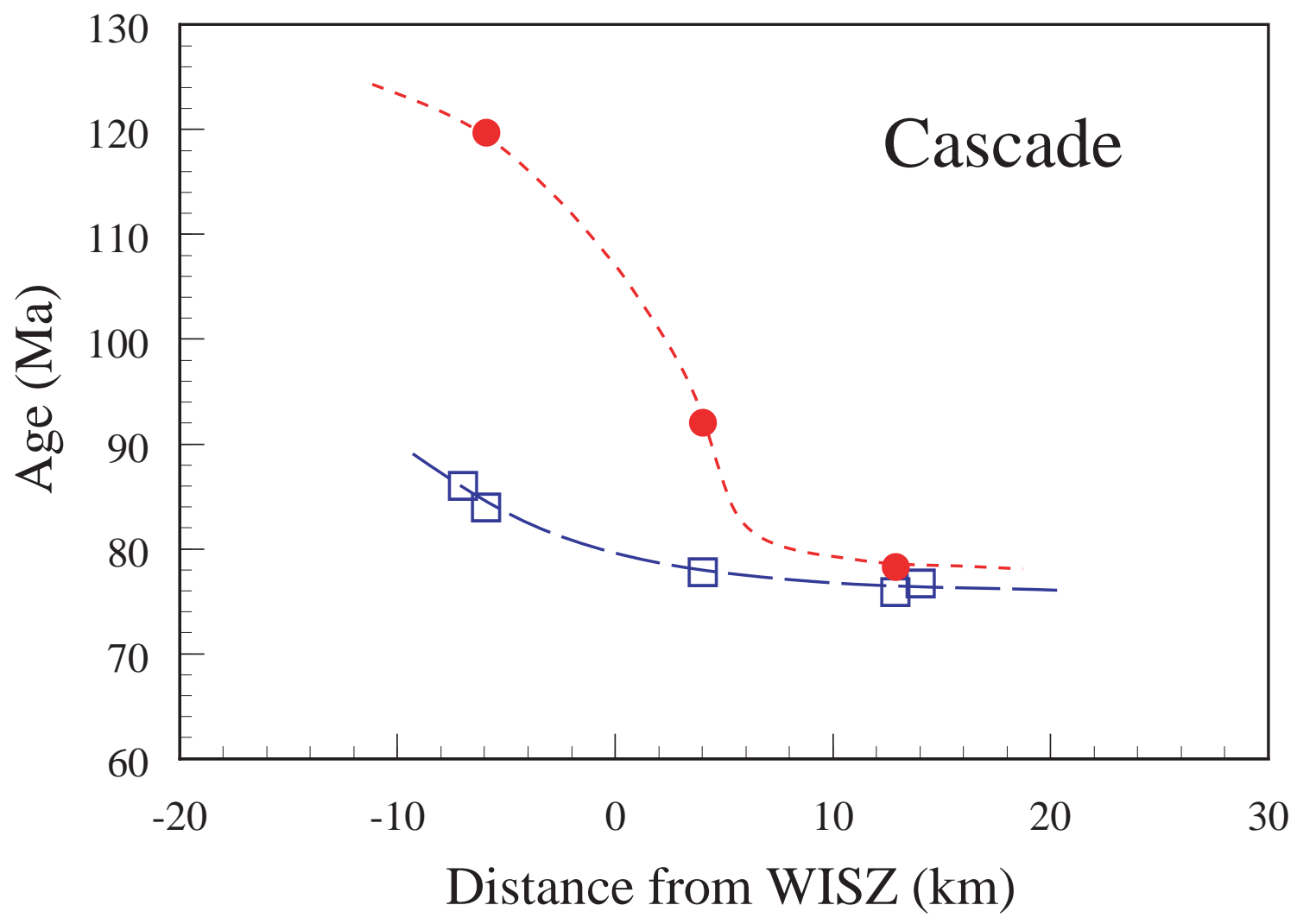

Figure 18. West-east profile centered approximately on Cascade, Idaho (Fig 1). Distance is given in kilometers with negative distances shown to the west of the WISZ. Symbols are as in Fig. 10.

Plutons east of the WISZ also have discordant biotite and hornblende ages, but in contrast to the pattern observed near Orofino, the discordance continues across the zone, approaching zero about $13 \mathrm{~km}$ to the east. This pattern suggests that $92 \mathrm{Ma}$ old plutons similar to the Payette River tonalite of Manduca and others (1992, 1993) occupy the suture zone, which shows little effect on hornblende K-Ar ages. Results are more consistent with thermal disturbance of the argon systems by younger plutons of the Idaho batholith to the east and may be unrelated to movement on the WISZ. The hornblende ages suggest that deformation along the WISZ probably has not been significant after about $92 \mathrm{Ma}$. Considering primary movement on the WISZ to have been complete by $92 \mathrm{Ma}$, biotite ages in this area must relate to the pattern of regional cooling following emplacement of the western margin of the Atlanta lobe of the Idaho batholith. This same, smooth pattern is reflected by biotite along the western edges of the Bitterroot lobe (Criss and Fleck, 1987) and the Sierra Nevada batholith (Evernden and Kistler, 1970), whereas hornblende values define a series of plutonic episodes in each of these areas. Although additional hornblende ages within the actual suture zone near Cascade could clarify the timing of deformation, a minimum age of about $92 \mathrm{Ma}$ is indicated for hornblende recrystallization and/or cooling in this area.

\section{DISCUSSION AND CONCLUSIONS}

Chemical and isotopic results from plutons emplaced into the Wallowa, Seven Devils, and related terranes, the Belt, Yellowjacket, and related Proterozoic (cratonal) terranes, and the western Idaho suture zone that forms the boundary between them confirm its significance as a 
major crustal-scale feature, marking the Mesozoic continental margin of North America. As demonstrated by Fleck and Criss (1985) and Fleck (1990), plutons emplaced into and deformed by the suture zone, represent mixtures of components derived from sources in both the accreted and cratonal lithospheres. Location with respect to the WISZ strongly controls magma chemistry and isotopic composition, in effect proportioning the broad range of lithospheric mantle, lower crust, and upper crustal components incorporated into the melt from each of the two lithospheres. These characteristics may be used in turn to locate the accretionary boundary, even where it has been engulfed completely by younger plutons. Suture-zone magmas are chemically unique, characterized by high $\mathrm{Sr}, \mathrm{Nb}, \mathrm{Nb} / \mathrm{Y}$, and $\mathrm{Nd} / \mathrm{Y}$, low $\mathrm{Rb} / \mathrm{Nb}$ ratios, and $\mathrm{Sr}$ and $\mathrm{Nd}$ isotopic compositions near "bulk earth" values. The latter translate into initial ${ }^{87} \mathrm{Sr} /{ }^{86} \mathrm{Sr}$ ratios averaging about 0.7045 and $E_{\mathrm{Nd}}(\mathrm{t})$ values between about -5 and 2 for the lithospheres involved in western Idaho.

Although argon geochronology restricted the timing of accretion of the WSD terranes to North America to the 135 to 75 Ma interval in Idaho (Fleck and Criss, 1985; Criss and Fleck, 1987), detailed understanding of the timing of suturing requires use of techniques such as U-Pb zircon studies to establish events such as emplacement age. Further progress will require careful geologic mapping of the suture zone and additional U-Pb, Sm-Nd, or Rb-Sr geochronology. Manduca and others (1993) and Lund and Snee (1988) are the only recent studies providing U$\mathrm{Pb}$ zircon ages that provide critical emplacement ages of units within and adjacent to the suture zone, but these represent only a few plutons. Sm-Nd ages on garnet reported by Getty and others (1993) suggest a $128 \mathrm{Ma}$ age for peak metamorphism of the WSD terranes following initial accretion. Because $\mathrm{K}-\mathrm{Ar}$ and ${ }^{40} \mathrm{Ar} /{ }^{39} \mathrm{Ar}$ apparent ages are affected by plutonic and tectonic events, however, these ages may provide useful information through patterns of age discordance revealed. Minerals with different "closure temperatures" (Dodson, 1973, 1979), yield different apparent ages when subjected to prolonged cooling or subsequent thermal events. Strain and recrystallization may disturb or "reset" argon geochronometers independent of closure temperatures, yielding concordant or nearly concordant ages that approach the time of disturbance, not the age of the rock. Generally accepted closure temperatures for biotite and hornblende at geologically average cooling rates are $280^{\circ} \pm 40^{\circ} \mathrm{C}$ (Harrison and McDougall, 1980) and $530^{\circ} \pm 40^{\circ} \mathrm{C}$ (Harrison, 1981), respectively. In the current study age profiles across the suture zone have demonstrated that the suture remained the locus of continued thermal and tectonic activity long after initial accretion. Because largely undisturbed plutons, which were emplaced in the accreted terranes prior to suturing, extend to within 5 to $10 \mathrm{~km}$ of the suture zone, their ages represent a maximum age for accretion. This places a limiting age for accretion at about $135 \mathrm{Ma}$.

Patterns of biotite and hornblende ages from rocks of the accreted terranes (WSD) exhibit the greatest discordance at distances of 2 to $10 \mathrm{~km}$ west of the suture zone (Figs. 9, 10, 12, 17, and 18). Near Orofino, hornblende ages decrease abruptly from about $135 \mathrm{Ma}$ and reach a minimum of about 74 Ma within the WISZ. Discordance between hornblende and biotite ages along the WISZ is variable, probably due to a combination of differing uplift rates, thermal effects from younger plutons, and deformation. The highly strained rocks of the suture zone yield the least discordant mineral pairs, but discordance remains at about 2 to $8 \mathrm{~m}$.y. east of the zone. This is consistent with immediate retention of Ar by hornblende following recrystallization at temperatures below its closure temperature, but with more prolonged cooling for biotite closure. Hornblende ages within the WISZ probably establish a reliable age for cessation of deformation, especially of rapid vertical translation within the zone (Fig. 10). 
Hornblende ages within the zone from Orofino to Kooskia indicate a minimum age for closure of about 74 Ma (Figs. 10-12). At the SFCR profile (Fig. 14) biotite and muscovite yield nearly concordant $\mathrm{K}-\mathrm{Ar}$ and ${ }^{40} \mathrm{Ar} /{ }^{39} \mathrm{Ar}$ ages at about $76 \mathrm{Ma}$, whereas hornblende ages average about 82 Ma. Results for rocks at Slate Creek yield a similar age for hornblende closure (Fig. 15), although older ages obtained from hornblende in plutonic inclusions have been used by Lund and Snee (1988) and Snee and others (1995) to establish an age of about 90 Ma. Uncertainties about complete loss of Ar inherited from their parent rock suggest that these represent maximum ages for recrystallization within the WISZ, however. Hornblende ages from deformed tonalite within the WISZ along the Salmon River indicate deformation continued there until about 85 Ma (Fig. 16). Manduca and others (1993) report a zircon U-Pb age of about $90 \mathrm{Ma}$ for a sample of tonalite roughly $12 \mathrm{~km}$ east of the WISZ in the Granite Mountain area. Although a 90-Ma age may reflect cessation of deformation, this tonalite is well outside the zone of highest strain. Evidence from hornblende within the deformed rocks suggests deformation may have continued until 85-82 Ma in this area (cf. Fig. 17). None of the samples around Cascade occurs within the WISZ, but tonalite less than $4 \mathrm{~km}$ east of the suture yields a hornblende K-Ar age of $92 \mathrm{Ma}$, consistent with cooling of that body below about $530^{\circ} \mathrm{C}$ and with a maximum age for completion of deformation of the pluton. A biotite age for this sample is highly discordant (Fig. 18), consistent with thermal effects from younger intrusions east of that location.

Ages for hornblende from deformed rocks within the western Idaho suture zone appear to decrease from south to north, ranging from as early as $92 \mathrm{Ma}$ in the area of Cascade to $74 \mathrm{Ma}$ or less at Orofino and the Weippe Bend (Fig. 19). We suggest that these ages represent the approximate end of deformation within a given section of the WISZ and the time when recrystallization ceased and temperatures were below about $530^{\circ} \mathrm{C}$. The suture zone was clearly the site of greatest differential movement within the area deformed during collision. This is documented by being the locus of flaser gneisses, syntectonic plutons, and magmatic epidoteand garnet-bearing tonalites and trondhjemites (e.g., Zen and Hammarstrom, 1984; Strayer and others, 1989; Selverstone and others, 1992), as well as by isotopic evidence that it coincides with the terrane boundary. The progression of hornblende ages along the suture suggests that this deformation did not occur simultaneously along the length of the WISZ, but migrated from south to north. We suggest that the differences observed in apparent ages of suture-zone rocks from Cascade to near Weippe and Orofino (Fig. 19) are related to the timing of rapid uplift of cratonal terranes and emplacement of younger plutons subsequent to accretion. Whether it is the cause or the effect, the ages of the Idaho batholith decrease from the Atlanta lobe in the south to the Bitterroot lobe in the north, similar to ages of suture zone hornblendes. Magmatism in the southern (Atlanta) lobe ranges from 120 to about $70 \mathrm{Ma}$, whereas most of the northern (Bitterroot) lobe was emplaced from about 80 to 55 Ma (Armstrong and others, 1977; Criss and others, 1982; Criss and Fleck, 1987; Lewis and others, 1987; Snee and others, 1995). If deformation along the WISZ was related to extreme vertical movements such as necessary to 


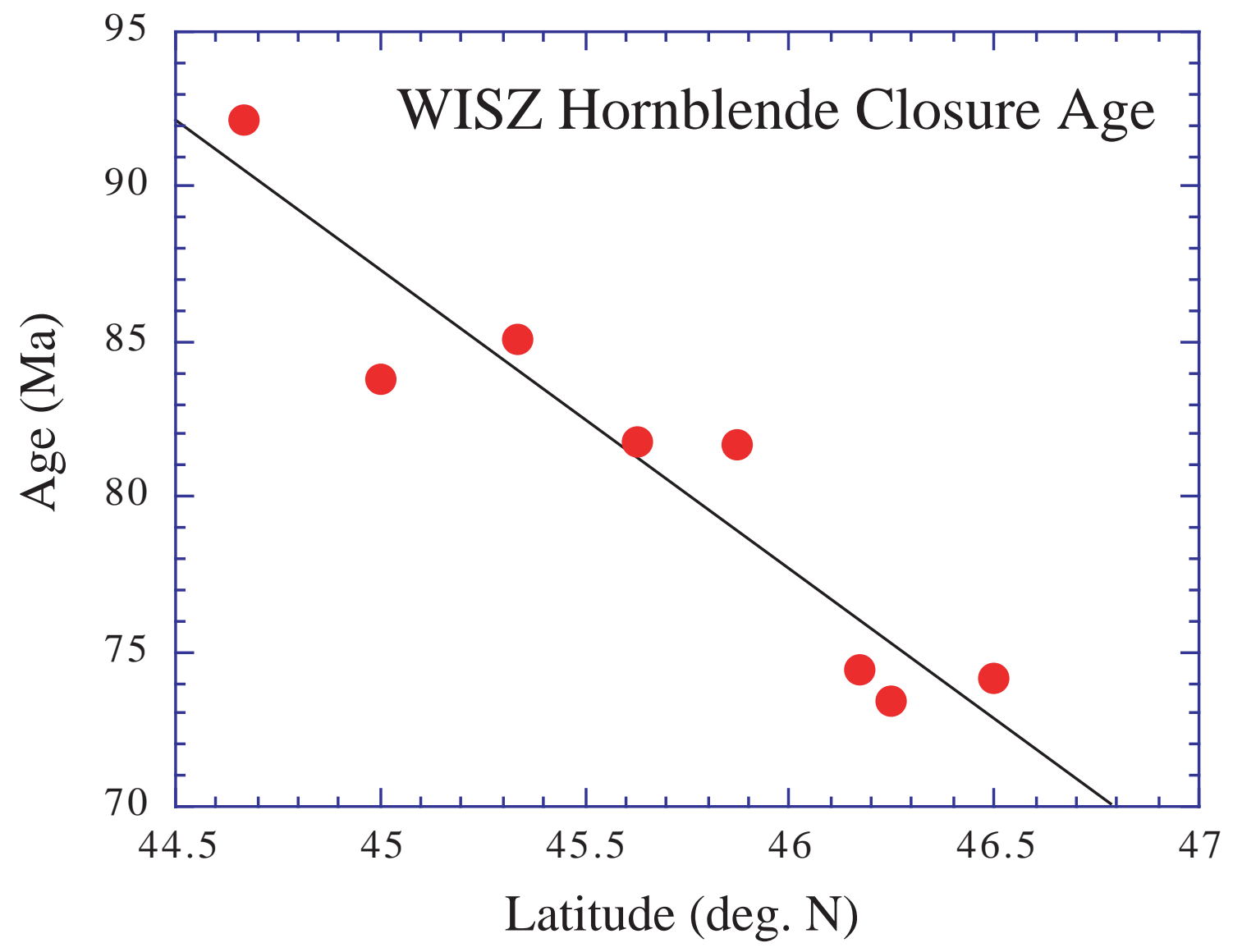

Figure 19. Summary of Ar closure ages for hornblende, calculated as the average age of hornblende at the WISZ for each of the profiles shown in Figs. 10-18. Generally, this is the average of available hornblende ages for samples within $2 \mathrm{~km}$ of the suture zone. Geologic variability is difficult to determine for small numbers of samples, although analytical precision for each age is commonly between 1 and 2 m.y. at one standard deviation (Table 3). These data indicate that the time of cooling or recrystallization of hornblende in the suture zone varied along the zone, favoring a progression of precipitous vertical movements over synchronous lateral displacement along the WISZ. The regression line shown is for reference only and not intended as an estimate of the timing at any given latitude. Practically, there are 3 or, perhaps 4 groups of closure ages along the suture zone, but age difference between the northern and southern groups is easily significant at any reasonable level of confidence.

bring magmatic-epidote-bearing tonalites to their present positions and this rapid rise of cratonal terranes was related to emplacement of batholithic-scale silicic magmas, much of the deformation along the WISZ may be a consequence of the south to north migration of Idaho batholith emplacement. The decrease in apparent ages of hornblende within the WISZ from over 
$90 \mathrm{Ma}$ in the south to less than $75 \mathrm{Ma}$ near Weippe and Orofino supports this model. If deformation were not synchronous along the WISZ but progressed from south to north analogous to batholith emplacement, then models of synchronous, transcurrent shearing along the WISZ may be precluded. Additionally, the coincidence of the WISZ and the terrane boundary may be the result of reactivation of the initial suture zone as emplacement of batholithic-scale silicic magmas within the zone and the western margin of the cratonal terranes resulted in their precipitous rise.

\section{REFERENCES CITED}

Armstrong, R. L., 1974, Geochronometry of the Eocene volcanic-plutonic episode in Idaho: Northwest Geology, v.3, p.1-15.

Armstrong, R. L., 1975, The geochronometry of Idaho: Isochron/ West, no.14, 50p.

Armstrong, R. L., 1976, The geochronometry of Idaho (part 2): Isochron/ West, no.15, p.1-33.

Armstrong, R. L., Taubeneck, W. H., and Hales, P. O., 1977, Rb-Sr and K-Ar geochronometry of Mesozoic granitic rocks and their Sr isotopic composition, Oregon, Washington, and Idaho: Geol. Soc. America Bull., v. 88, p. 397-411.

Ave Lallemant, H.G., Phelps, D.W., and Sutter, J.F., 1980, ${ }^{40} \mathrm{Ar} /{ }^{39} \mathrm{Ar}$ ages of some pre-Tertiary plutonic and metamorphic rocks of eastern Oregon and their tectonic relationships: Geology, v.8, p.371-374.

Ave Lallemant, H.G., Schmidt, W.J., and Kraft, J.L., 1985, Major Late Triassic strike-slip displacement in the Seven Devils terrane, Oregon and Idaho: a result of left-oblique plate convergence?: Tectonophysics, v.19, p.299-328.

Beaulieu, J.D., 1974, Geologic formations of eastern Oregon (east of longitude 121³0’): Oregon Dept. of Geology and Mineral Industries, Map GMS-7.

Bonnichsen, Bill, 1987, Pre-Cenozoic geology of the West Mountain-Council Mountain-New Meadows area, west-central Idaho: in, Vallier, T. L. and Brooks, H. C., eds., The Idaho Batholith and its Border Zone, U. S. Geol. Survey Prof. Paper 1436, p.151-170.

Brooks, H.C. and Vallier, T.L., 1978, Mesozoic rocks and tectonic evolution of eastern Oregon and western Idaho: in Howell, D.G., and MacDougall, K.A., eds., Mesozoic Paleogeography of the Western United States: Pacific Coast Paleogeography Symposium 2d, Society of Economic Paleontologists and Mineralogists, p.133-146.

Carlson, R.W., 1984, Isotopic constraints on Columbia River flood basalt genesis and the nature of the subcontinental mantle: Geochim. Cosmochim. Acta, v.48, p.2357-2372.

Carlson, R. W., Lugmair, G. W., and Macdougall, J. D., 1981, Columbia River volcanism: the question of mantle heterogeneity or crustal contamination: Geochim. Cosmochim. Acta, v.45, p. 2483-2499.

Criss, R. E. and Fleck, R. J., 1987, Petrogenesis, geochronology, and hydrothermal systems of the northern Idaho batholith and adjacent areas based on ${ }^{18} \mathrm{O} /{ }^{16} \mathrm{O}, \mathrm{D} / \mathrm{H},{ }^{87} \mathrm{Sr} /{ }^{86} \mathrm{Sr}, \mathrm{K}-\mathrm{Ar}$, and ${ }^{40} \mathrm{Ar} /{ }^{39} \mathrm{Ar}$ studies: in Vallier, T. L. and Brooks, H. C., eds., The Idaho Batholith and its Border Zone, U. S. Geol. Survey Prof. Paper 1436, p. 95-137.

Criss, R.E., Lanphere, M.A., and Taylor, H.P., Jr., 1982, Effects of regional uplift, deformation, and meteoric-hydrothermal metamorphism on K-Ar ages of biotites in the southern half of the Idaho batholith: Jour. Geophys. Research, v.87, no.B8, p.7029-7046.

DePaolo, D.J. and Wasserburg, G.J., 1976, Nd isotopic variations and petrogenetic models: Geophysical Research Letters, V.3, no.5, p.249-252. 
DePaolo, D.J. and Wasserburg, G.J., 1979, Petrogenetic mixing models and Nd-Sr isotopic patterns: Geochim. Cosmochim. Acta, v.43, p.615-627.

Dodson, M. H., 1973, Closure temperature in cooling geochronological and petrological systems: Contrib. Mineral. Petrol., v. 40, p. 259-274.

Dodson, M. H., 1979, Theory of cooling ages: in Jäger, E. and Hunziger, J.C., eds., Lectures in Isotope Geology, Springer-Verlag, Berlin, 329p.

Evernden, J. F. and Kistler, R. W., 1970, Chronology of emplacement of Mesozoic batholithic complexes in California and western Nevada: U.S. Geol. Survey Prof. Paper 623, 42p.

Fleck, R. J., 1990, Neodymium, strontium, and trace element evidence of crustal anatexis and magma mixing in the Idaho batholith, in Anderson, J.L., ed., The nature and origin of Cordilleran magmatism: Boulder, Colorado, Geol. Soc. America Memoir 174, p.359-373.

Fleck, R. J. and Criss, R. E., 1985, Strontium and oxygen isotopic variations in Mesozoic and Tertiary plutons of central Idaho: Contrib. Mineral. Petrol., v. 90, p. 291-308.

Fleck, R. J. and Criss, R. E., 1988, Location, age, and tectonic significance of the western Idaho suture zone (WISZ) and its relation to the Idaho batholith: Geol. Soc. America Abstracts with Programs, v. 20, no. 6, p.414.

Getty, S.R., Selverstone, J, Wernicke, B.P., Jacobsen, S.B., Aliberti, E., and Lux, D.R., 1993, Sm-Nd dating of multiple garnet growth events in an arc-continent collision zone, northwestern U.S. Cordillera: Contrib. Mineral. Petrol., v.115, p.45-57.

Hamilton, W.B., 1963a, Metamorphism in the Riggins region western Idaho: U.S. Geol. Survey Prof. Paper 436, 95p.

Hamilton, W.B., 1963b, Overlapping of late Mesozoic orogens in western Idaho: Geol. Soc. America Bull., v.74, p.779-788.

Hamilton, W.B., 1976, Tectonic history of west-central Idaho: Geol. Soc. America Abstracts with Programs, v.8, p.378.

Harrison, T.M., 1981, Diffusion of ${ }^{40} \mathrm{Ar}$ in hornblende: Contrib. Mineral. Petrol., v.78, p.324331.

Harrison, T.M. and McDougall, I., 1980, Investigations of an intrusive contact, northwest Nelson, New Zealand-I. Thermal, chronological and isotopic constraints: Geochim. Cosmochim. Acta, v.44, p.1985-2003.

Hart, S. R., 1964, The petrology and isotopic mineral age relations of a contact zone in the Front Range, Colorado: J. Geol., v.72, p.493-525.

Hart, W.K., 1985, Chemical and isotopic evidence for the mixing between depleted and enriched mantle, northwestern U.S.A.: Geochim. Cosmochim. Acta, v.49, p.131-144.

Hietanen, A., 1962, Metasomatic metamorphism in western Clearwater County, Idaho: U.S. Geol. Survey Prof. Paper 344A, 116p.

Hietanen, A., 1963a, Metamorphism of the Belt series in the Elk River-Clarkia area, Idaho: U.S. Geol. Survey Prof. Paper 344-C, 78p.

Hietanen, A., 1963b, Idaho batholith near Pierce and Bungalow, Clearwater County, Idaho: U.S. Geol. Survey Prof. Paper 344-D, 42p.

Hietanen, A., 1967, Scapolite in the Belt Series in the St. Joe-Clearwater region, Idaho: Geol. Soc. America Special Paper 86, 56p.

Hoover, A.L., 1986, Transect across the Salmon River suture, South Fork of the Clearwater River, western Idaho: rare earth element, geochemical, structural and metamorphic study: MS thesis, Oregon State University, Corvallis, OR, 138p. 
Hunziker, J.C., Desmons, J., and Hurford, A.J., 1992, Thirty-two years of geochronological work in the central and western Alps: a review on seven maps: Memoires de Geologie (Lausanne), no.13, 59p.

Jäger, E., Niggli, E, and Wenk, E., 1967, Rb-Sr Alterbestimmungen an Glimmern der Zentralalpen: Beitrag zur geol. Karte der Schweiz, NF 134, Lieferungen, Kummerly and Frey, Bern, 67p.

Jones, D.L., Silberling, N.J., and Hillhouse, J, 1977, Wrangellia - A displaced continental block in northwestern North America: Canadian Jour. Earth Science, v.14, p.2565-2577.

Leeman, W. P. and Hawksworth, C. J., 1986, Open magma systems: trace element and isotopic constraints: Jour. Geophys. Res., v.91, p.5901-5912.

Lewis, R.S., Kiilsgaard, T.H., Bennett, E.H., and Hall, W.E., 1987, Lithological and chemical characteristics of the central and southeastern part of the southern lobe of the Idaho batholith: in Vallier, T. L. and Brooks, H. C., eds., The Idaho Batholith and its Border Zone, U. S. Geol. Survey Prof. Paper 1436, p.171-196.

Lund, K. and Snee, L.W., 1988, structural development, and age of the continent-island arc juncture in west-central Idaho: in, Ernst, W.G., ed., Metamorphism and Crustal Evolution of the Western United States, Prentice-Hall Pub., Englewood Cliffs, NJ, p.296-331.

Lund, K., 1995, Metamorphic and structural development of island-arc rock in the Slate CreekJohn Day Creek area, west-central Idaho: in, Vallier, T.L., Brooks, H.C., eds., Geology of the Blue Mountains Region of Oregon, Idaho, and Washington: petrology and tectonic evolution of pre-Tertiary rocks of the Blue Mountains Region: U.S. Geological Survey Professional Paper 1438, p.517-540.

Manduca, C.A., Silver, L.T., and Taylor, H.P., 1992, ${ }^{87} \mathrm{Sr} /{ }^{86} \mathrm{Sr}$ and ${ }^{18} \mathrm{O} /{ }^{16} \mathrm{O}$ isotopic systematics and geochemistry of granitoids plutons across a steeply-dipping boundary between contrasting lithospheric blocks in western Idaho: Contrib. Min. Petrol., v.109, p.355-372.

Manduca, C.A., Kuntz, M.A., and Silver, L.T., 1993, Emplacement and deformational history of the western margin of the Idaho batholith near McCall, Idaho: influence of a major terrane boundary: Geol. Soc. America Bull., v.105, p.749-765.

McDowell, F.W. and Kulp, J.L. 1969, Potassium-argon dating of the Idaho batholith: Geol. Soc. America Bull., v.80, p.2379-2382.

McCelland, W.C., Tikoff, B., and, Manduca, C.A., 2000, Two-phase evolution of accretionary margins: examples from the North American Cordillera: Tectonophysics, v.326, p.37-55.

Mullen, E.D., 1985, Petrologic character of Permian and Triassic greenstones from the mélange terrane of eastern Oregon and their implications for terrane origin: Geology, v.13, p.131134.

Myers, P.E., 1982, Geology of the Harpster area, Idaho County, Idaho: Idaho Bur. Mines Geol. Bull. 25, 46p.

Onasch, C. M., 1987, Temporal and spatial relations between folding, intrusion, metamorphism, and thrust faulting in the Riggins area, west-central Idaho: in Vallier, T. L. and Brooks, H. C., eds., The Idaho Batholith and its Border Zone, U. S. Geol. Survey Prof. Paper 1436, p. 139-149.

Pearce, J. A., Harris, N. B. W., and Tindle, A. G., 1984, Trace element discrimination diagrams for the tectonic interpretation of granitic rocks: Jour. Petrol., v. 25, p. 956-983.

Selverstone, J., Wernicke, B.P., and Aliberti, E.A., 1992, Intracontinental subduction and hinged unroofing along the Salmon River suture zone, west central Idaho: Tectonics, v.11, no.1, p.124-144. 
Snee, L.W., Lund, K., Sutter, J.F., Balcer, D.E., and Evans, K.V., 1995, An 40Ar/39Ar chronicle of the tectonic development of the Salmon River suture zone, western Idaho: in: Vallier, T.L., Brooks, H.C. (eds.), Geology of the Blue Mountains Region of Oregon, Idaho, and Washington: Petrology and Tectonic Evolution of Pre-Tertiary Rocks of the Blue Mountains Region, U.S. Geol. Survey Professional Paper 1438, p.359-414.

Strayer, L. M. IV, and Hyndman, D. W. 1987, Movement direction and displacement estimate in the western Idaho suture zone mylonite: Dworshak Dam/Orofino area, west central Idaho: Geol. Soc. America Abstracts with Programs, v. 19, no. 7, p. 857.

Strayer, L.M., Sears, J.W., and Hyndman, D.W., 1988, Western Idaho suture zone (I): Evidence for a structural and metamorphic culmination: Geol. Soc. America Abstracts with Programs, v. 20, p.471.

Strayer, L. M., Hyndman, D. W., Sears, J.W., and Myers, P.E., 1989, Direction and shear sense during suturing of the Seven Devils-Wallowa terrane against North America in western Idaho: Geology, v.17, p.1025-1028.

Taubeneck, W. H., 1971, Idaho batholith and its southern extension: Geol. Soc. America Bull., v.82, p.1899-1928.

Vallier, T.L., 1974, Preliminary report on the geology of part of the Snake River Canyon: Oregon Dept. Geology and Mineral Industries, Map GMS-6, 28p.

Vallier, T.L., 1977, The Permian and Triassic Seven Devils Group: U.S. Geol. Survey Bull. 1437, 58p.

Vallier, T.L. and Brooks, H.C. (1987) The Idaho Batholith and its border zone: a regional Perspective. in: Vallier, T. L. and Brooks, H. C., eds., The Idaho Batholith and its Border Zone, U. S. Geol. Survey Prof. Paper 1436, p.1-7.

Vallier, T.L., Brooks, H.C., and Thayer, T.P., 1977, Paleozoic rocks of eastern Oregon and western Idaho: in Stewart, J. and others, eds., Paleozoic Paleogeography of the Western United States: Pacific Coast Paleogeography Symposium 1st, Society of Economic Paleontologists and Mineralogists, p.455-466.

Vallier, T.L. and Brooks, H.C. (eds.), 1995, Geology of the Blue Mountains Region of Oregon, Idaho, and Washington: Petrology and Tectonic Evolution of Pre-Tertiary Rocks of the Blue Mountains Region, U.S. Geol. Survey Professional Paper 1438, 540p.

Walker, G.W., 1977, Geologic map of Oregon east of the $121^{\text {st }}$ meridian: U.S. Geol Survey Miscellaneous Investigations Series Map I-902, scale 1:500,000.

Walker, N. W., 1995, Tectonic implications of U-Pb zircon ages of the Canyon Mountain complex, Sparta Complex, and related rocks of the Baker terrane, northeastern Oregon: in: Vallier, T.L., Brooks, H.C. (eds.), Geology of the Blue Mountains Region of Oregon, Idaho, and Washington: Petrology and Tectonic Evolution of Pre-Tertiary Rocks of the Blue Mountains Region, U.S. Geol. Survey Professional Paper 1438, p.247-269.

Wiswall, C.G. and Hyndman, D.W., 1987, Emplacement of the main plutons of the Bitterroot lobe of the Idaho batholith: in Vallier, T. L. and Brooks, H. C., eds., The Idaho Batholith and its Border Zone, U. S. Geol. Survey Prof. Paper 1436, p.59-72.

Zen, E. and Hammarstrom, J.M., 1984, Magmatic epidote and its petrologic significance, Geology, v.12, p.515-518. 
TABLES

Table 1. Results of Rb-Sr Analyses

\begin{tabular}{|c|c|c|c|c|c|c|c|c|c|c|}
\hline Sample No. & N. Latitude & W. Longitude & $\mathrm{Rb}$ & $\mathrm{Sr}$ & $\mathrm{Rb} / \mathrm{Sr}$ & ${ }^{87} \mathrm{Rb} /{ }^{86} \mathrm{Sr}$ & ${ }^{87} \mathrm{Sr} /{ }^{86} \mathrm{Sr}$ & $\left({ }^{87} \mathrm{Sr} /{ }^{86} \mathrm{Sr}\right)_{\mathrm{i}}$ & Age (Ma) & $\mathrm{Sr}_{\mathrm{i}}$ \\
\hline 00RL503 & $46^{\circ} 32.657^{\prime}$ & $116^{\circ} 33.645^{\prime}$ & 86 & 308 & 0.27922 & 0.808395 & 0.714516 & 0.713482 & 90 & 0.7135 \\
\hline 00RL508 & $46^{\circ} 33.234^{\prime}$ & $116^{\circ} 33.002^{\prime}$ & 41 & 742 & 0.05526 & 0.159872 & 0.707874 & 0.707670 & 90 & 0.7077 \\
\hline 00RL589 & $46^{\circ} 31.98^{\prime}$ & $116^{\circ} 18.435^{\prime}$ & 21 & 569 & 0.03691 & 0.106735 & 0.703299 & 0.703163 & 90 & 0.7032 \\
\hline $797-15 A$ & $44^{\circ} 05.041^{\prime}$ & $116^{\circ} 06.245^{\prime}$ & 72.35 & 769.2 & 0.09406 & 0.272123 & 0.70723 & 0.706963 & 70 & 0.7070 \\
\hline 797-15B & $44^{\circ} 05.566^{\prime}$ & $116^{\circ} 02.294^{\prime}$ & 58.6 & 836.3 & 0.07006 & 0.202687 & 0.70720 & 0.706998 & 70 & 0.7070 \\
\hline 797-15C & $44^{\circ} 04.119^{\prime}$ & $115^{\circ} 43.662^{\prime}$ & 82.6 & 1102.0 & 0.07492 & 0.216737 & 0.70672 & 0.706578 & 45 & 0.7066 \\
\hline $797-16 A$ & $43^{\circ} 58.621^{\prime}$ & $115^{\circ} 19.798^{\prime}$ & 167.7 & 83.9 & 1.99998 & 5.787693 & 0.70992 & 0.706220 & 45 & 0.7062 \\
\hline $797-16 B$ & $43^{\circ} 58.806^{\prime}$ & $115^{\circ} 19.539^{\prime}$ & 138.5 & 404.1 & 0.34279 & 0.991774 & 0.707535 & 0.706901 & 45 & 0.7069 \\
\hline 797-16C & $43^{\circ} 58.832^{\prime}$ & $115^{\circ} 19.271^{\prime}$ & 143.2 & 345.4 & 0.41453 & 1.199279 & 0.70708 & 0.706314 & 45 & 0.7063 \\
\hline 797-16D & $43^{\circ} 59.893^{\prime}$ & $115^{\circ} 17.155^{\prime}$ & 71.5 & 546.6 & 0.13074 & 0.378378 & 0.71113 & 0.710755 & 70 & 0.7108 \\
\hline $797-16 \mathrm{~F}$ & $43^{\circ} 55.017^{\prime}$ & $115^{\circ} 23.376^{\prime}$ & 36.6 & 745.8 & 0.04909 & 0.142050 & 0.70950 & 0.709362 & 70 & 0.7094 \\
\hline $807-24 B$ & $44^{\circ} 07.161^{\prime}$ & $115^{\circ} 22.573^{\prime}$ & 50.6 & 756 & 0.06693 & 0.193686 & 0.70966 & 0.709467 & 70 & 0.7095 \\
\hline 807-24D & $44^{\circ} 04.075^{\prime}$ & $115^{\circ} 31.306^{\prime}$ & 74.7 & 588 & 0.12704 & 0.367633 & 0.70971 & 0.709340 & 70 & 0.7093 \\
\hline $807-24 \mathrm{E}$ & $44^{\circ} 04.275^{\prime}$ & $115^{\circ} 24.402^{\prime}$ & 92.2 & 546 & 0.16886 & 0.488571 & 0.70776 & 0.707451 & 45 & 0.7075 \\
\hline $807-24 \mathrm{~F}$ & $44^{\circ} 01.623^{\prime}$ & $115^{\circ} 28.11^{\prime}$ & 81.5 & 633 & 0.12875 & 0.372539 & 0.70843 & 0.708062 & 70 & 0.7081 \\
\hline $807-25 A$ & $44^{\circ} 18.383^{\prime}$ & $115^{\circ} 17.417^{\prime}$ & 160.0 & 129 & 1.24031 & 3.589707 & 0.71105 & 0.708756 & 45 & 0.7088 \\
\hline $807-25 B$ & $44^{\circ} 13.333^{\prime}$ & $115^{\circ} 05.833^{\prime}$ & 154.0 & 133 & 1.15789 & 3.351192 & 0.71109 & 0.708946 & 45 & 0.7089 \\
\hline 818-17A & $44^{\circ} 22.001^{\prime}$ & $115^{\circ} 16.236^{\prime}$ & 76.2 & 1517.0 & 0.05023 & 0.145314 & 0.70655 & 0.706405 & 70 & 0.7064 \\
\hline 818-17B & $44^{\circ} 27.214^{\prime}$ & $115^{\circ} 23.415^{\prime}$ & 154.0 & 610.0 & 0.25246 & 0.730508 & 0.70883 & 0.708104 & 70 & 0.7081 \\
\hline 818-17C & $44^{\circ} 28.150^{\prime}$ & $115^{\circ} 41.388^{\prime}$ & 69.7 & 1056.0 & 0.06600 & 0.190941 & 0.706380 & 0.706190 & 70 & 0.7062 \\
\hline 818-17D & $44^{\circ} 29.296^{\prime}$ & $115^{\circ} 39.209^{\prime}$ & 138.0 & 684.0 & 0.20175 & 0.583689 & 0.70705 & 0.706470 & 70 & 0.7065 \\
\hline $818-17 \mathrm{E}$ & $44^{\circ} 26.883^{\prime}$ & $115^{\circ} 13.832^{\prime}$ & 40.7 & 608.0 & 0.06694 & 0.193686 & 0.70818 & 0.707987 & 70 & 0.7080 \\
\hline $818-17 F$ & $44^{\circ} 24.472^{\prime}$ & $115^{\circ} 33.406^{\prime}$ & 80.2 & 785.0 & 0.10217 & 0.295593 & 0.70776 & 0.707466 & 70 & 0.7075 \\
\hline 818-18A & $44^{\circ} 10.047^{\prime}$ & $115^{\circ} 33.668^{\prime}$ & 112.0 & 308.0 & 0.36364 & 1.052412 & 0.71081 & 0.709763 & 70 & 0.7098 \\
\hline 818-18B & $43^{\circ} 55.065^{\prime}$ & $115^{\circ} 23.282^{\prime}$ & 48.0 & 737.0 & 0.06513 & 0.188467 & 0.70946 & 0.709273 & 70 & 0.7093 \\
\hline 818-18C & $43^{\circ} 55.043^{\prime}$ & $115^{\circ} 23.339^{\prime}$ & 47.7 & 790.0 & 0.06038 & 0.174724 & 0.70944 & 0.709266 & 70 & 0.7093 \\
\hline
\end{tabular}




\begin{tabular}{|c|c|c|c|c|c|c|c|c|c|c|}
\hline $827-25 F$ & $46^{\circ} 36.393^{\prime}$ & $117^{\circ} 21.676^{\prime}$ & 76.98 & 577.6 & 0.13328 & 0.385632 & 0.708550 & 0.708112 & 80 & 0.7081 \\
\hline $827-25 G$ & $46^{\circ} 36.222^{\prime}$ & $117^{\circ} 21.440^{\prime}$ & 83.58 & 375.1 & 0.22282 & 0.644775 & 0.709270 & 0.708537 & 80 & 0.7085 \\
\hline $827-25 \mathrm{H}$ & $46^{\circ} 36.222^{\prime}$ & $117^{\circ} 21.440^{\prime}$ & 96.15 & 291.5 & 0.32985 & 0.954517 & 0.709740 & 0.708655 & 80 & 0.7087 \\
\hline $827-25 I$ & $46^{\circ} 36.222^{\prime}$ & $117^{\circ} 21.440^{\prime}$ & 86.26 & 347.4 & 0.24830 & 0.718501 & 0.709150 & 0.708333 & 80 & 0.7083 \\
\hline 837-22A & $46^{\circ} 39.507^{\prime}$ & $116^{\circ} 47.642^{\prime}$ & 96.31 & 785.5 & 0.12261 & 0.354938 & 0.713370 & 0.712967 & 80 & 0.7130 \\
\hline $837-22 B$ & $46^{\circ} 39.354^{\prime}$ & $116^{\circ} 47.601^{\prime}$ & 63.76 & 805.4 & 0.07917 & 0.229145 & 0.712100 & 0.711840 & 80 & 0.7118 \\
\hline $837-22 C$ & $46^{\circ} 37.365^{\prime}$ & $116^{\circ} 48.981^{\prime}$ & 54.08 & 820.5 & 0.06591 & 0.190752 & 0.710610 & 0.710393 & 80 & 0.7104 \\
\hline 837-22D & $46^{\circ} 37.227^{\prime}$ & $116^{\circ} 48.849^{\prime}$ & 63.33 & 717.5 & 0.08826 & 0.255457 & 0.711100 & 0.710810 & 80 & 0.7108 \\
\hline 837-30A & $45^{\circ} 10.454^{\prime}$ & $116^{\circ} 16.556^{\prime}$ & 1.80 & 884.8 & 0.00203 & 0.005884 & 0.703866 & 0.703859 & 80 & 0.7039 \\
\hline 837-30B & $45^{\circ} 5.017^{\prime}$ & $116^{\circ} 13.373^{\prime}$ & 22.74 & 628.2 & 0.03620 & 0.104705 & 0.705110 & 0.704991 & 80 & 0.7050 \\
\hline 837-30C & $45^{\circ} 3.772^{\prime}$ & $116^{\circ} 15.724^{\prime}$ & 31.24 & 520.6 & 0.06001 & 0.173558 & 0.704220 & 0.704023 & 80 & 0.7040 \\
\hline 837-30D & $45^{\circ} 1.402^{\prime}$ & $116^{\circ} 13.232^{\prime}$ & 12.02 & 819.8 & 0.01466 & 0.042406 & 0.703919 & 0.703871 & 80 & 0.7039 \\
\hline 837-30E & $44^{\circ} 58.780^{\prime}$ & $116^{\circ} 10.03^{\prime}$ & 24.07 & 926.4 & 0.02598 & 0.075156 & 0.705360 & 0.705275 & 80 & 0.7053 \\
\hline 837-30F & $44^{\circ} 57.230^{\prime}$ & $116^{\circ} 08.559^{\prime}$ & 24.42 & 851.4 & 0.02868 & 0.082976 & 0.706655 & 0.706561 & 80 & 0.7066 \\
\hline 837-31A & $45^{\circ} 16.465^{\prime}$ & $116^{\circ} 09.596^{\prime}$ & 31.08 & 947.5 & 0.03280 & 0.094880 & 0.705035 & 0.704927 & 80 & 0.7049 \\
\hline 837-31B & $45^{\circ} 15.563^{\prime}$ & $116^{\circ} 08.923^{\prime}$ & 29.41 & 1212.0 & 0.02427 & 0.070189 & 0.705090 & 0.705010 & 80 & 0.7050 \\
\hline 837-31C & $45^{\circ} 12.999^{\prime}$ & $116^{\circ} 09.005^{\prime}$ & 52.64 & 837.8 & 0.06283 & 0.181748 & 0.705543 & 0.705336 & 80 & 0.7053 \\
\hline 837-31D & $45^{\circ} 11.819^{\prime}$ & $116^{\circ} 08.602^{\prime}$ & 53.68 & 893.4 & 0.06009 & 0.173814 & 0.706122 & 0.705924 & 80 & 0.7059 \\
\hline $837-31 E$ & $45^{\circ} 11.332^{\prime}$ & $116^{\circ} 09.503^{\prime}$ & 17.89 & 812.7 & 0.02201 & 0.063672 & 0.704917 & 0.704845 & 80 & 0.7048 \\
\hline $837-31 F$ & $45^{\circ} 11.332^{\prime}$ & $116^{\circ} 09.503^{\prime}$ & 41.72 & 1142.0 & 0.03653 & 0.105668 & 0.704860 & 0.704740 & 80 & 0.7047 \\
\hline $837-31 G$ & $45^{\circ} 09.305^{\prime}$ & $116^{\circ} 10.214^{\prime}$ & 76.12 & 718.4 & 0.10596 & 0.306473 & 0.704710 & 0.704362 & 80 & 0.7044 \\
\hline $837-31 \mathrm{H}$ & $45^{\circ} 07.320^{\prime}$ & $116^{\circ} 10.133^{\prime}$ & 73.12 & 777.2 & 0.09408 & 0.272121 & 0.704695 & 0.704386 & 80 & 0.7044 \\
\hline 837-31I & $45^{\circ} 05.788^{\prime}$ & $116^{\circ} 09.790^{\prime}$ & 61.10 & 730.0 & 0.08370 & 0.242104 & 0.705295 & 0.705020 & 80 & 0.7050 \\
\hline 837-31J & $45^{\circ} 03.473^{\prime}$ & $116^{\circ} 09.249^{\prime}$ & 30.23 & 1298.0 & 0.02329 & 0.067362 & 0.704561 & 0.704484 & 80 & 0.7045 \\
\hline $837-31 \mathrm{~K}$ & $45^{\circ} 02.536^{\prime}$ & $116^{\circ} 07.993^{\prime}$ & 23.28 & 1056.0 & 0.02205 & 0.063773 & 0.706013 & 0.705941 & 80 & 0.7059 \\
\hline 837-31L & $45^{\circ} 09.541^{\prime}$ & $116^{\circ} 06.579^{\prime}$ & 60.70 & 668.0 & 0.09087 & 0.262903 & 0.707641 & 0.707342 & 80 & 0.7073 \\
\hline $837-31 M$ & $45^{\circ} 08.434^{\prime}$ & $116^{\circ} 07.093^{\prime}$ & 58.55 & 667.8 & 0.08768 & 0.253669 & 0.707709 & 0.707421 & 80 & 0.7074 \\
\hline $837-31 N$ & $45^{\circ} 06.257^{\prime}$ & $116^{\circ} 07.313^{\prime}$ & 45.49 & 807.2 & 0.05636 & 0.163053 & 0.707890 & 0.707705 & 80 & 0.7077 \\
\hline 837-31P & $45^{\circ} 06.541^{\prime}$ & $116^{\circ} 04.540^{\prime}$ & 67.79 & 571.8 & 0.11856 & 0.343072 & 0.709532 & 0.709142 & 80 & 0.7091 \\
\hline 837-31Q & $45^{\circ} 02.823^{\prime}$ & $116^{\circ} 07.350^{\prime}$ & 12.76 & 1192.0 & 0.01070 & 0.030967 & 0.706380 & 0.706345 & 80 & 0.7063 \\
\hline 837-31R & $45^{\circ} 02.823^{\prime}$ & $116^{\circ} 07.350^{\prime}$ & 9.87 & 1171.0 & 0.00843 & 0.024392 & 0.706835 & 0.706807 & 80 & 0.7068 \\
\hline
\end{tabular}




\begin{tabular}{|c|c|c|c|c|c|c|c|c|c|c|}
\hline 838-1A & $45^{\circ} 05.433^{\prime}$ & $116^{\circ} 02.656^{\prime}$ & 55.04 & 700.9 & 0.07853 & 0.227232 & 0.709150 & 0.708892 & 80 & 0.7089 \\
\hline 838-1B & $45^{\circ} 09.289^{\prime}$ & $115^{\circ} 59.639^{\prime}$ & 37.23 & 976.4 & 0.03813 & 0.110327 & 0.708398 & 0.708273 & 80 & 0.7083 \\
\hline 838-1C & $45^{\circ} 15.998^{\prime}$ & $115^{\circ} 51.040^{\prime}$ & 123.10 & 461.9 & 0.26651 & 0.771192 & 0.709255 & 0.708378 & 80 & 0.7084 \\
\hline 838-1D & $45^{\circ} 15.362^{\prime}$ & $115^{\circ} 53.871^{\prime}$ & 74.57 & 505.6 & 0.14749 & 0.426739 & 0.708148 & 0.707663 & 80 & 0.7077 \\
\hline $838-1 \mathrm{E}$ & $45^{\circ} 12.054^{\prime}$ & $115^{\circ} 57.338^{\prime}$ & 57.15 & 959.5 & 0.05956 & 0.172343 & 0.708555 & 0.708359 & 80 & 0.7084 \\
\hline $838-1 F$ & $45^{\circ} 12.054^{\prime}$ & $115^{\circ} 57.338^{\prime}$ & 79.64 & 631.9 & 0.12603 & 0.364682 & 0.708758 & 0.708343 & 80 & 0.7083 \\
\hline $838-1 G$ & $45^{\circ} 12.148^{\prime}$ & $115^{\circ} 59.705^{\prime}$ & 90.11 & 654.9 & 0.13759 & 0.398130 & 0.708650 & 0.708197 & 80 & 0.7082 \\
\hline 838-1H & $45^{\circ} 08.352^{\prime}$ & $116^{\circ} 00.658^{\prime}$ & 36.25 & 862.3 & 0.04204 & 0.121639 & 0.708608 & 0.708470 & 80 & 0.7085 \\
\hline 838-1I & $45^{\circ} 06.840^{\prime}$ & $116^{\circ} 01.416^{\prime}$ & 53.88 & 757.5 & 0.07113 & 0.205816 & 0.708850 & 0.708616 & 80 & 0.7086 \\
\hline $838-1 \mathrm{~J}$ & $45^{\circ} 03.500^{\prime}$ & $116^{\circ} 03.090^{\prime}$ & 96.35 & 642.4 & 0.14998 & 0.433988 & 0.708760 & 0.708267 & 80 & 0.7083 \\
\hline 838-1K & $45^{\circ} 03.500^{\prime}$ & $116^{\circ} 03.090^{\prime}$ & 112.20 & 655.1 & 0.17127 & 0.495589 & 0.708882 & 0.708319 & 80 & 0.7083 \\
\hline 838-1L & $44^{\circ} 59.961^{\prime}$ & $116^{\circ} 04.157^{\prime}$ & 98.20 & 612.4 & 0.16035 & 0.463952 & 0.707950 & 0.707423 & 80 & 0.7074 \\
\hline 838-1M & $44^{\circ} 58.385^{\prime}$ & $116^{\circ} 06.839^{\prime}$ & 55.76 & 700.4 & 0.07961 & 0.230354 & 0.708455 & 0.708193 & 80 & 0.7082 \\
\hline $838-1 N$ & $44^{\circ} 57.400^{\prime}$ & $116^{\circ} 08.703^{\prime}$ & 19.58 & 713.3 & 0.02745 & 0.079417 & 0.707355 & 0.707265 & 80 & 0.7073 \\
\hline $838-2 A$ & $44^{\circ} 57.362^{\prime}$ & $116^{\circ} 08.79^{\prime}$ & 24.06 & 1188.0 & 0.02025 & 0.058605 & 0.709253 & 0.709186 & 80 & 0.7092 \\
\hline 838-2B & $44^{\circ} 57.494^{\prime}$ & $116^{\circ} 09.054^{\prime}$ & 11.80 & 1399.0 & 0.00843 & 0.024401 & 0.706835 & 0.706807 & 80 & 0.7068 \\
\hline 838-2C & $44^{\circ} 57.570^{\prime}$ & $116^{\circ} 09.650^{\prime}$ & 19.29 & 967.3 & 0.01994 & 0.057688 & 0.706060 & 0.705994 & 80 & 0.7060 \\
\hline 838-2D & $44^{\circ} 58.311^{\prime}$ & $116^{\circ} 09.807^{\prime}$ & 22.57 & 801.2 & 0.02817 & 0.081495 & 0.706556 & 0.706463 & 80 & 0.7065 \\
\hline $838-2 \mathrm{E}$ & $44^{\circ} 45.097^{\prime}$ & $116^{\circ} 11.58^{\prime}$ & 53.63 & 830.3 & 0.06459 & 0.186816 & 0.704274 & 0.704062 & 80 & 0.7041 \\
\hline $838-2 F$ & $44^{\circ} 45.015^{\prime}$ & $116^{\circ} 12.512^{\prime}$ & 76.65 & 1668.0 & 0.04595 & 0.132910 & 0.704284 & 0.704133 & 80 & 0.7041 \\
\hline $838-2 G$ & $44^{\circ} 45.305^{\prime}$ & $116^{\circ} 13.468^{\prime}$ & 112.70 & 1776.0 & 0.06346 & 0.183535 & 0.704200 & 0.703991 & 80 & 0.7040 \\
\hline $838-2 \mathrm{H}$ & $44^{\circ} 45.373^{\prime}$ & $116^{\circ} 10.365^{\prime}$ & 38.28 & 944.6 & 0.04053 & 0.117231 & 0.706125 & 0.705992 & 80 & 0.7060 \\
\hline 838-2I & $44^{\circ} 46.646^{\prime}$ & $116^{\circ} 01.293^{\prime}$ & 80.71 & 520.5 & 0.15506 & 0.448715 & 0.709534 & 0.709024 & 80 & 0.7090 \\
\hline $838-2 \mathrm{~J}$ & $44^{\circ} 46.632^{\prime}$ & $116^{\circ} 01.326^{\prime}$ & 62.74 & 510.0 & 0.12302 & 0.355986 & 0.709400 & 0.708995 & 80 & 0.7090 \\
\hline 838-3A & $44^{\circ} 04.114^{\prime}$ & $115^{\circ} 48.397^{\prime}$ & 68.75 & 564.5 & 0.12179 & 0.352417 & 0.709151 & 0.708750 & 80 & 0.7088 \\
\hline 838-3B & $44^{\circ} 14.572^{\prime}$ & $116^{\circ} 00.658^{\prime}$ & 108.80 & 310.3 & 0.35063 & 1.014651 & 0.709655 & 0.708502 & 80 & 0.7085 \\
\hline 838-3C & $44^{\circ} 13.865^{\prime}$ & $115^{\circ} 59.109^{\prime}$ & 113.40 & 641.6 & 0.17675 & 0.511338 & 0.707060 & 0.706479 & 80 & 0.7065 \\
\hline 838-3D & $44^{\circ} 17.137^{\prime}$ & $115^{\circ} 56.913^{\prime}$ & 47.64 & 694.3 & 0.06862 & 0.198529 & 0.707994 & 0.707768 & 80 & 0.7078 \\
\hline 838-3E & $44^{\circ} 18.476^{\prime}$ & $115^{\circ} 51.895^{\prime}$ & 106.00 & 625.4 & 0.16949 & 0.490432 & 0.708755 & 0.708198 & 80 & 0.7082 \\
\hline 838-3F & $44^{\circ} 15.137^{\prime}$ & $115^{\circ} 53.427^{\prime}$ & 104.00 & 544.2 & 0.19111 & 0.552993 & 0.709075 & 0.708446 & 80 & 0.7084 \\
\hline 838-3G & $44^{\circ} 13.672^{\prime}$ & $115^{\circ} 54.229^{\prime}$ & 129.70 & 127.7 & 1.01566 & 2.939709 & 0.711678 & 0.708337 & 80 & 0.7083 \\
\hline
\end{tabular}




\begin{tabular}{|c|c|c|c|c|c|c|c|c|c|c|}
\hline $858-12 \mathrm{~A}$ & $45^{\circ} 15.414^{\prime}$ & $115^{\circ} 40.144^{\prime}$ & 75.30 & 727.2 & 0.10355 & 0.299608 & 0.708971 & 0.708630 & 80 & 0.7087 \\
\hline 858-12B & $45^{\circ} 13.644^{\prime}$ & $115^{\circ} 37.086^{\prime}$ & 85.88 & 576.9 & 0.14886 & 0.430765 & 0.709383 & 0.708893 & 80 & 0.7089 \\
\hline 858-12C & $45^{\circ} 14.764^{\prime}$ & $115^{\circ} 38.806^{\prime}$ & 101.77 & 618.1 & 0.16464 & 0.476408 & 0.709118 & 0.708576 & 80 & 0.7087 \\
\hline 858-12D & $45^{\circ} 22.626^{\prime}$ & $115^{\circ} 59.42^{\prime}$ & 106.95 & 547.5 & 0.19535 & 0.565261 & 0.708603 & 0.707960 & 80 & 0.7080 \\
\hline $858-12 E$ & $45^{\circ} 22.395^{\prime}$ & $116^{\circ} 00.667^{\prime}$ & 82.76 & 579.0 & 0.14293 & 0.413543 & 0.708013 & 0.707543 & 80 & 0.7075 \\
\hline $858-12 F$ & $45^{\circ} 24.487^{\prime}$ & $116^{\circ} 00.974^{\prime}$ & 121.00 & 562.4 & 0.21514 & 0.622534 & 0.709001 & 0.708293 & 80 & 0.7083 \\
\hline 858-13A & $45^{\circ} 19.329^{\prime}$ & $115^{\circ} 47.648^{\prime}$ & 115.92 & 323.9 & 0.35785 & 1.035937 & 0.713446 & 0.712269 & 80 & 0.7122 \\
\hline 858-13C & $45^{\circ} 16.525^{\prime}$ & $115^{\circ} 41.698^{\prime}$ & 95.39 & 453.3 & 0.21044 & 0.609118 & 0.712081 & 0.711389 & 80 & 0.7114 \\
\hline 858-13D & $45^{\circ} 15.652^{\prime}$ & $115^{\circ} 43.273^{\prime}$ & 87.05 & 628.9 & 0.13843 & 0.400598 & 0.709034 & 0.708579 & 80 & 0.7085 \\
\hline 858-13E & $45^{\circ} 14.198^{\prime}$ & $115^{\circ} 46.572^{\prime}$ & 129.66 & 429.5 & 0.30186 & 0.875260 & 0.709289 & 0.708294 & 80 & 0.7083 \\
\hline $858-13 F$ & $45^{\circ} 15.471^{\prime}$ & $115^{\circ} 53.838^{\prime}$ & 97.76 & 451.1 & 0.21673 & 0.627139 & 0.709166 & 0.708453 & 80 & 0.7085 \\
\hline 858-13G & $45^{\circ} 23.653^{\prime}$ & $115^{\circ} 51.844^{\prime}$ & 70.93 & 120.1 & 0.59043 & 1.709149 & 0.713073 & 0.711130 & 80 & 0.7111 \\
\hline 858-13H & $45^{\circ} 22.728^{\prime}$ & $115^{\circ} 51.371^{\prime}$ & 99.45 & 541.5 & 0.18365 & 0.531500 & 0.710537 & 0.709933 & 80 & 0.7099 \\
\hline $877-12 \mathrm{~A}$ & $43^{\circ} 42.700^{\prime}$ & $116^{\circ} 09.757^{\prime}$ & 109.08 & 509.5 & 0.21411 & 0.619515 & 0.708419 & 0.707715 & 80 & 0.7077 \\
\hline 877-12B & $43^{\circ} 42.887^{\prime}$ & $116^{\circ} 09.761^{\prime}$ & 72.17 & 581.4 & 0.12413 & 0.359121 & 0.707066 & 0.706658 & 80 & 0.7067 \\
\hline $877-12 C$ & $43^{\circ} 43.813^{\prime}$ & $116^{\circ} 08.277^{\prime}$ & 72.92 & 627.5 & 0.11621 & 0.336199 & 0.706851 & 0.706469 & 80 & 0.7065 \\
\hline 877-12D & $43^{\circ} 45.102^{\prime}$ & $116^{\circ} 06.376^{\prime}$ & 94.22 & 617.3 & 0.15264 & 0.441603 & 0.707000 & 0.706498 & 80 & 0.7065 \\
\hline $877-12 E$ & $43^{\circ} 44.009^{\prime}$ & $116^{\circ} 05.107^{\prime}$ & 67.22 & 528.2 & 0.12726 & 0.368205 & 0.708348 & 0.707929 & 80 & 0.7079 \\
\hline $877-12 F$ & $43^{\circ} 41.844^{\prime}$ & $116^{\circ} 05.358^{\prime}$ & 71.92 & 600.4 & 0.11979 & 0.346611 & 0.708305 & 0.707911 & 80 & 0.7079 \\
\hline $877-12 \mathrm{G}$ & $43^{\circ} 41.197^{\prime}$ & $116^{\circ} 02.830^{\prime}$ & 64.99 & 621.2 & 0.10462 & 0.302731 & 0.709332 & 0.708988 & 80 & 0.7090 \\
\hline $877-12 \mathrm{H}$ & $43^{\circ} 40.898^{\prime}$ & $116^{\circ} 02.932^{\prime}$ & 62.51 & 594.7 & 0.10510 & 0.304198 & 0.711170 & 0.710824 & 80 & 0.7108 \\
\hline $877-12 \mathrm{I}$ & $43^{\circ} 38.475^{\prime}$ & $116^{\circ} 01.011^{\prime}$ & 100.41 & 325.5 & 0.30850 & 0.892440 & 0.706291 & 0.705277 & 80 & 0.7053 \\
\hline 877-13A & $43^{\circ} 21.302^{\prime}$ & $115^{\circ} 27.011^{\prime}$ & 155.15 & 814.7 & 0.19043 & 0.550953 & 0.707475 & 0.706849 & 80 & 0.7068 \\
\hline 877-13B & $43^{\circ} 21.431^{\prime}$ & $115^{\circ} 27.083^{\prime}$ & 66.72 & 972.6 & 0.06860 & 0.198479 & 0.707558 & 0.707332 & 80 & 0.7073 \\
\hline 877-13E & $43^{\circ} 24.703^{\prime}$ & $115^{\circ} 33.749^{\prime}$ & 67.71 & 113.7 & 0.59562 & 1.725377 & 0.720160 & 0.718199 & 80 & 0.7182 \\
\hline $877-13 F$ & $43^{\circ} 22.675^{\prime}$ & $115^{\circ} 32.845^{\prime}$ & 104.13 & 366.0 & 0.28451 & 0.824188 & 0.720545 & 0.719608 & 80 & 0.7196 \\
\hline 877-17E & $44^{\circ} 52.488^{\prime}$ & $116^{\circ} 51.955^{\prime}$ & 5.79 & 46.8 & 0.12380 & 0.358084 & 0.705047 & 0.703671 & 270 & 0.7037 \\
\hline 877-18A & $44^{\circ} 28.498^{\prime}$ & $116^{\circ} 15.936^{\prime}$ & 30.83 & 953.6 & 0.03233 & 0.093515 & 0.704762 & 0.704656 & 80 & 0.7047 \\
\hline 877-18B & $44^{\circ} 26.336^{\prime}$ & $116^{\circ} 16.156^{\prime}$ & 31.63 & 924.3 & 0.03422 & 0.098975 & 0.704603 & 0.704491 & 80 & 0.7045 \\
\hline 877-18C & $44^{\circ} 26.462^{\prime}$ & $116^{\circ} 15.482^{\prime}$ & 17.68 & 1093.2 & 0.01617 & 0.046780 & 0.704961 & 0.704908 & 80 & 0.7049 \\
\hline 877-18D & $44^{\circ} 26.421^{\prime}$ & $116^{\circ} 14.389^{\prime}$ & 39.77 & 669.7 & 0.05938 & 0.171767 & 0.704853 & 0.704658 & 80 & 0.7047 \\
\hline
\end{tabular}




\begin{tabular}{|c|c|c|c|c|c|c|c|c|c|c|}
\hline 877-18E & $44^{\circ} 26.474^{\prime}$ & $116^{\circ} 14.111^{\prime}$ & 24.92 & 978.6 & 0.02547 & 0.073662 & 0.705409 & 0.705325 & 80 & 0.7053 \\
\hline $877-18 F$ & $44^{\circ} 27.845^{\prime}$ & $116^{\circ} 13.56^{\prime}$ & 50.45 & 541.5 & 0.09316 & 0.269527 & 0.707150 & 0.706844 & 80 & 0.7067 \\
\hline 877-18G & $44^{\circ} 28.071^{\prime}$ & $116^{\circ} 12.444^{\prime}$ & 5.33 & 7.45 & 0.71544 & 2.074406 & 0.729766 & 0.727408 & 80 & 0.7274 \\
\hline 877-18H & $44^{\circ} 27.74^{\prime}$ & $116^{\circ} 12.19^{\prime}$ & 96.36 & 892.6 & 0.10796 & 0.312446 & 0.710731 & 0.710376 & 80 & 0.7104 \\
\hline 877-18I & $44^{\circ} 27.74^{\prime}$ & $116^{\circ} 12.19^{\prime}$ & 46.44 & 536.2 & 0.08660 & 0.250626 & 0.710012 & 0.709727 & 80 & 0.7097 \\
\hline 877-18J & $44^{\circ} 26.749^{\prime}$ & $116^{\circ} 12.693^{\prime}$ & 32.97 & 900.2 & 0.03663 & 0.105985 & 0.709349 & 0.709229 & 80 & 0.7092 \\
\hline 877-18K & $44^{\circ} 23.128^{\prime}$ & $116^{\circ} 14.745^{\prime}$ & 12.58 & 787.1 & 0.01598 & 0.046233 & 0.705254 & 0.705201 & 80 & 0.7052 \\
\hline 877-19A & $43^{\circ} 54.803^{\prime}$ & $116^{\circ} 16.486^{\prime}$ & 99.92 & 546.6 & 0.18281 & 0.528948 & 0.708363 & 0.707762 & 80 & 0.7078 \\
\hline 877-19B & $43^{\circ} 54.776^{\prime}$ & $116^{\circ} 16.445^{\prime}$ & 105.61 & 621.2 & 0.17000 & 0.491863 & 0.707656 & 0.707097 & 80 & 0.7071 \\
\hline 877-19C & $43^{\circ} 54.353^{\prime}$ & $116^{\circ} 14.024^{\prime}$ & 67.22 & 808.3 & 0.08317 & 0.240608 & 0.707161 & 0.706888 & 80 & 0.7069 \\
\hline 877-19D & $44^{\circ} 31.724^{\prime}$ & $116^{\circ} 8.193^{\prime}$ & 72.67 & 857.5 & 0.08475 & 0.245238 & 0.709233 & 0.708954 & 80 & 0.7090 \\
\hline 877-19E & $44^{\circ} 33.508^{\prime}$ & $116^{\circ} 9.956^{\prime}$ & 51.15 & 602.5 & 0.08490 & 0.245677 & 0.709126 & 0.708847 & 80 & 0.7088 \\
\hline 877-19F & $44^{\circ} 34.586^{\prime}$ & $116^{\circ} 10.825^{\prime}$ & 45.66 & 707.3 & 0.06455 & 0.186782 & 0.708673 & 0.708461 & 80 & 0.7085 \\
\hline 877-19G & $44^{\circ} 34.586^{\prime}$ & $116^{\circ} 10.825^{\prime}$ & 45.91 & 692.7 & 0.06627 & 0.191773 & 0.709207 & 0.708989 & 80 & 0.7090 \\
\hline 877-19H & $44^{\circ} 34.627^{\prime}$ & $116^{\circ} 11.263^{\prime}$ & 52.39 & 565.3 & 0.09267 & 0.268131 & 0.708214 & 0.707909 & 80 & 0.7079 \\
\hline $877-20 A$ & $44^{\circ} 26.606^{\prime}$ & $116^{\circ} 08.058^{\prime}$ & 68.60 & 385.8 & 0.17780 & 0.514508 & 0.709272 & 0.708687 & 80 & 0.7087 \\
\hline 877-20B & $44^{\circ} 25.015^{\prime}$ & $116^{\circ} 07.862^{\prime}$ & 112.38 & 557.8 & 0.20146 & 0.582843 & 0.707366 & 0.706704 & 80 & 0.7067 \\
\hline 877-20C & $44^{\circ} 26.19^{\prime}$ & $116^{\circ} 08.589^{\prime}$ & 112.91 & 556.4 & 0.20294 & 0.587184 & 0.707965 & 0.707298 & 80 & 0.7073 \\
\hline 877-20D & $44^{\circ} 26.19^{\prime}$ & $116^{\circ} 08.589^{\prime}$ & 52.31 & 534.8 & 0.09782 & 0.283114 & 0.711018 & 0.710696 & 80 & 0.7107 \\
\hline $877-20 \mathrm{E}$ & $44^{\circ} 25.844^{\prime}$ & $116^{\circ} 09.767^{\prime}$ & 30.02 & 889.8 & 0.03374 & 0.097630 & 0.709594 & 0.709483 & 80 & 0.7095 \\
\hline $877-20 F$ & $44^{\circ} 25.027^{\prime}$ & $116^{\circ} 05.773^{\prime}$ & 80.88 & 714.2 & 0.11325 & 0.327618 & 0.706482 & 0.706110 & 80 & 0.7061 \\
\hline 877-20G & $44^{\circ} 23.826^{\prime}$ & $116^{\circ} 03.497^{\prime}$ & 89.15 & 676.9 & 0.13170 & 0.381111 & 0.709300 & 0.708867 & 80 & 0.7089 \\
\hline $877-20 \mathrm{H}$ & $44^{\circ} 18.165^{\prime}$ & $116^{\circ} 05.548^{\prime}$ & 71.00 & 719.5 & 0.09868 & 0.285555 & 0.709211 & 0.708886 & 80 & 0.7089 \\
\hline 877-20I & $44^{\circ} 19.059^{\prime}$ & $116^{\circ} 07.989^{\prime}$ & 90.75 & 558.3 & 0.16256 & 0.470268 & 0.706688 & 0.706153 & 80 & 0.7062 \\
\hline $877-20 \mathrm{~J}$ & $44^{\circ} 20.102^{\prime}$ & $116^{\circ} 10.494^{\prime}$ & 69.13 & 523.3 & 0.13210 & 0.382195 & 0.707491 & 0.707057 & 80 & 0.7071 \\
\hline $877-20 \mathrm{~K}$ & $44^{\circ} 20.169^{\prime}$ & $116^{\circ} 10.964^{\prime}$ & 57.12 & 725.2 & 0.07876 & 0.227912 & 0.708905 & 0.708646 & 80 & 0.7086 \\
\hline 877-20L & $44^{\circ} 19.944^{\prime}$ & $116^{\circ} 12.08^{\prime}$ & 44.31 & 639.8 & 0.06925 & 0.200413 & 0.710094 & 0.709866 & 80 & 0.7099 \\
\hline 877-20M & $44^{\circ} 21.165^{\prime}$ & $116^{\circ} 13.167^{\prime}$ & 17.14 & 795.5 & 0.02155 & 0.062326 & 0.705970 & 0.705899 & 80 & 0.7059 \\
\hline $877-21 \mathrm{~A}$ & $44^{\circ} 41.299^{\prime}$ & $116^{\circ} 00.058^{\prime}$ & 62.02 & 639.4 & 0.09700 & 0.280685 & 0.708962 & 0.708643 & 80 & 0.7086 \\
\hline $877-21 B$ & $44^{\circ} 41.006^{\prime}$ & $115^{\circ} 59.105^{\prime}$ & 62.02 & 750.7 & 0.08262 & 0.239063 & 0.709267 & 0.708995 & 80 & 0.7090 \\
\hline 877-21C & $44^{\circ} 41.52^{\prime}$ & $115^{\circ} 52.799^{\prime}$ & 78.86 & 608.5 & 0.12960 & 0.375000 & 0.709015 & 0.708589 & 80 & 0.7086 \\
\hline
\end{tabular}




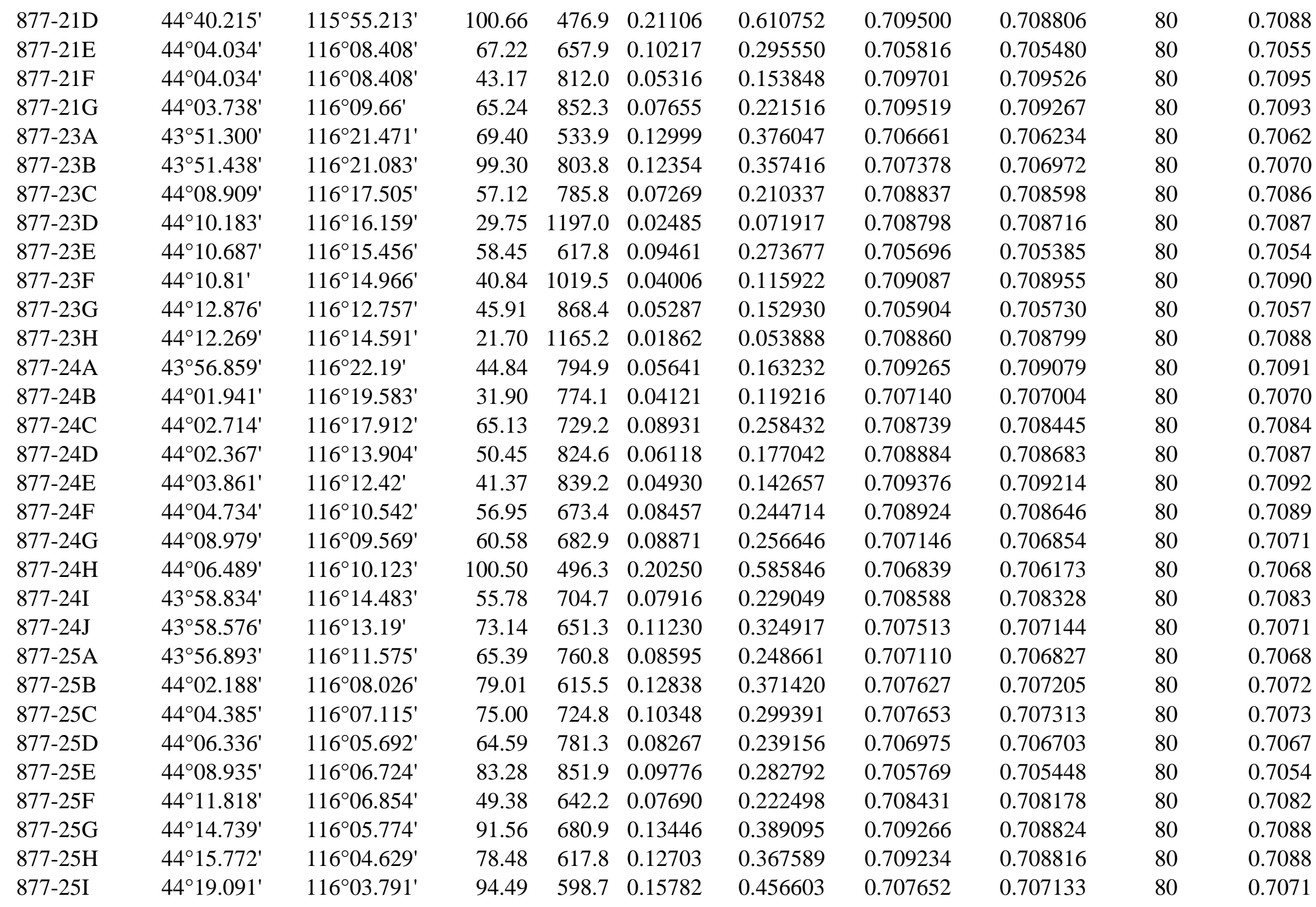




\begin{tabular}{|c|c|c|c|c|c|c|c|c|c|c|}
\hline $877-25 \mathrm{~J}$ & $44^{\circ} 27.256^{\prime}$ & $115^{\circ} 54.574^{\prime}$ & 82.48 & 590.9 & 0.13959 & 0.403829 & 0.706971 & 0.706512 & 80 & 0.7065 \\
\hline $877-25 \mathrm{~K}$ & $44^{\circ} 24.991^{\prime}$ & $115^{\circ} 56.507^{\prime}$ & 74.74 & 765.2 & 0.09767 & 0.282605 & 0.708596 & 0.708275 & 80 & 0.7083 \\
\hline 877-26A & $44^{\circ} 27.801^{\prime}$ & $116^{\circ} 02.483^{\prime}$ & 91.56 & 707.2 & 0.12947 & 0.374653 & 0.709436 & 0.709010 & 80 & 0.7090 \\
\hline 877-26B & $44^{\circ} 24.907^{\prime}$ & $116^{\circ} 01.976^{\prime}$ & 100.90 & 534.1 & 0.18891 & 0.546656 & 0.709481 & 0.708860 & 80 & 0.7089 \\
\hline $877-26 C$ & $44^{\circ} 31.478^{\prime}$ & $116^{\circ} 02.947^{\prime}$ & 98.76 & 602.5 & 0.16391 & 0.474302 & 0.709422 & 0.708883 & 80 & 0.7089 \\
\hline 877-26D & $44^{\circ} 31.548^{\prime}$ & $116^{\circ} 03.004^{\prime}$ & 78.74 & 680.7 & 0.11567 & 0.334719 & 0.709135 & 0.708755 & 80 & 0.7088 \\
\hline $877-26 E$ & $44^{\circ} 34.917^{\prime}$ & $116^{\circ} 02.410^{\prime}$ & 78.21 & 695.5 & 0.11245 & 0.325377 & 0.709129 & 0.708759 & 80 & 0.7088 \\
\hline $877-26 \mathrm{~F}$ & $44^{\circ} 58.453^{\prime}$ & $115^{\circ} 57.332^{\prime}$ & 48.58 & 851.0 & 0.05708 & 0.165172 & 0.708674 & 0.708486 & 80 & 0.7085 \\
\hline 877-26G & $45^{\circ} 01.570^{\prime}$ & $115^{\circ} 42.454^{\prime}$ & 89.69 & 459.3 & 0.19526 & 0.565242 & 0.713305 & 0.712663 & 80 & 0.7127 \\
\hline $877-26 \mathrm{H}$ & $45^{\circ} 02.718^{\prime}$ & $115^{\circ} 45.028^{\prime}$ & 95.83 & 474.2 & 0.20210 & 0.585034 & 0.712842 & 0.712177 & 80 & 0.7122 \\
\hline $877-26 \mathrm{I}$ & $45^{\circ} 04.130^{\prime}$ & $115^{\circ} 49.975^{\prime}$ & 88.35 & 482.4 & 0.18314 & 0.529937 & 0.709249 & 0.708647 & 80 & 0.7086 \\
\hline $877-26 \mathrm{~J}$ & $45^{\circ} 03.046^{\prime}$ & $115^{\circ} 53.772^{\prime}$ & 71.80 & 654.2 & 0.10975 & 0.317559 & 0.708745 & 0.708384 & 80 & 0.7084 \\
\hline $877-26 \mathrm{~K}$ & $45^{\circ} 02.402^{\prime}$ & $115^{\circ} 55.909^{\prime}$ & 70.20 & 915.4 & 0.07668 & 0.221900 & 0.709207 & 0.708955 & 80 & 0.7090 \\
\hline 877-26L & $44^{\circ} 55.075^{\prime}$ & $115^{\circ} 58.274^{\prime}$ & 145.48 & 380.3 & 0.38252 & 1.106931 & 0.709590 & 0.708332 & 80 & 0.7083 \\
\hline 877-26M & $44^{\circ} 55.087^{\prime}$ & $115^{\circ} 58.311^{\prime}$ & 102.50 & 505.1 & 0.20293 & 0.587339 & 0.711173 & 0.710505 & 80 & 0.7105 \\
\hline $887-22 A$ & $43^{\circ} 31.413^{\prime}$ & $115^{\circ} 18.212^{\prime}$ & 72.17 & 386.4 & 0.18676 & 0.540773 & 0.715713 & 0.715098 & 80 & 0.7151 \\
\hline $887-22 C$ & $43^{\circ} 24.020^{\prime}$ & $115^{\circ} 23.824^{\prime}$ & 88.03 & 1207.8 & 0.07288 & 0.210878 & 0.708219 & 0.707979 & 80 & 0.7080 \\
\hline 887-24A & $44^{\circ} 38.773^{\prime}$ & $116^{\circ} 14.751^{\prime}$ & 70.44 & 1235.5 & 0.05701 & 0.164900 & 0.704638 & 0.704451 & 80 & 0.7045 \\
\hline $887-24 B$ & $44^{\circ} 38.594^{\prime}$ & $116^{\circ} 14.103^{\prime}$ & 9.28 & 221.2 & 0.04193 & 0.121271 & 0.703775 & 0.703637 & 80 & 0.7036 \\
\hline $887-24 C$ & $44^{\circ} 41.014^{\prime}$ & $116^{\circ} 13.718^{\prime}$ & 3.05 & 300.1 & 0.01015 & 0.029359 & 0.703802 & 0.703769 & 80 & 0.7038 \\
\hline 887-24D & $44^{\circ} 41.023^{\prime}$ & $116^{\circ} 13.697^{\prime}$ & 15.01 & 207.9 & 0.07219 & 0.208773 & 0.703955 & 0.703718 & 80 & 0.7037 \\
\hline $887-24 \mathrm{E}$ & $44^{\circ} 41.023^{\prime}$ & $116^{\circ} 13.697^{\prime}$ & 115.52 & 93.3 & 1.23830 & 3.583232 & 0.709157 & 0.705084 & 80 & 0.7051 \\
\hline $887-24 \mathrm{~F}$ & $44^{\circ} 44.330^{\prime}$ & $116^{\circ} 13.439^{\prime}$ & 70.19 & 1516.4 & 0.04629 & 0.133879 & 0.704273 & 0.704121 & 80 & 0.7041 \\
\hline $887-24 G$ & $44^{\circ} 46.530^{\prime}$ & $116^{\circ} 12.516^{\prime}$ & 47.41 & 1420.2 & 0.03338 & 0.096546 & 0.704188 & 0.704078 & 80 & 0.7041 \\
\hline $887-24 \mathrm{H}$ & $44^{\circ} 39.704^{\prime}$ & $116^{\circ} 12.501^{\prime}$ & 41.18 & 473.2 & 0.08702 & 0.251715 & 0.704939 & 0.704653 & 80 & 0.7047 \\
\hline $887-24 \mathrm{I}$ & $44^{\circ} 36.496^{\prime}$ & $116^{\circ} 13.515^{\prime}$ & 22.74 & 552.0 & 0.04119 & 0.119129 & 0.704591 & 0.704456 & 80 & 0.7045 \\
\hline $887-24 J$ & $44^{\circ} 33.360^{\prime}$ & $116^{\circ} 15.349^{\prime}$ & 68.95 & 413.5 & 0.16673 & 0.482268 & 0.704862 & 0.704314 & 80 & 0.7043 \\
\hline $887-25 A$ & $43^{\circ} 45.554^{\prime}$ & $116^{\circ} 16.46^{\prime}$ & 79.85 & 627.1 & 0.12734 & 0.368430 & 0.707684 & 0.707265 & 80 & 0.7073 \\
\hline $887-25 B$ & $43^{\circ} 45.660^{\prime}$ & $116^{\circ} 15.995^{\prime}$ & 108.09 & 628.7 & 0.17192 & 0.497413 & 0.707937 & 0.707372 & 80 & 0.7074 \\
\hline $887-25 C$ & $43^{\circ} 49.721^{\prime}$ & $116^{\circ} 14.972^{\prime}$ & 51.89 & 866.4 & 0.05989 & 0.173288 & 0.707584 & 0.707387 & 80 & 0.7074 \\
\hline 887-25D & $43^{\circ} 52.296^{\prime}$ & $116^{\circ} 13.545^{\prime}$ & 65.48 & 874.4 & 0.07489 & 0.216686 & 0.707673 & 0.707427 & 80 & 0.7074 \\
\hline
\end{tabular}




\begin{tabular}{|c|c|c|c|c|c|c|c|c|c|c|}
\hline $887-25 E$ & $43^{\circ} 53.400^{\prime}$ & $116^{\circ} 11.717^{\prime}$ & 50.15 & 835.6 & 0.06002 & 0.173646 & 0.707469 & 0.707272 & 80 & 0.7073 \\
\hline $887-25 F$ & $43^{\circ} 53.014^{\prime}$ & $116^{\circ} 10.768^{\prime}$ & 63.25 & 911.3 & 0.06941 & 0.200830 & 0.707616 & 0.707387 & 80 & 0.7074 \\
\hline $887-25 G$ & $43^{\circ} 52.268^{\prime}$ & $116^{\circ} 06.995^{\prime}$ & 52.89 & 539.9 & 0.09797 & 0.283422 & 0.707150 & 0.706828 & 80 & 0.7068 \\
\hline $887-25 \mathrm{H}$ & $43^{\circ} 52.722^{\prime}$ & $116^{\circ} 04.120^{\prime}$ & 52.39 & 544.7 & 0.09619 & 0.278276 & 0.707006 & 0.706690 & 80 & 0.7067 \\
\hline $887-25 I$ & $43^{\circ} 54.297^{\prime}$ & $115^{\circ} 59.18^{\prime}$ & 71.43 & 181.9 & 0.39264 & 1.136025 & 0.707884 & 0.706593 & 80 & 0.7066 \\
\hline $887-25 \mathrm{~J}$ & $43^{\circ} 55.009^{\prime}$ & $115^{\circ} 56.594^{\prime}$ & 52.64 & 580.8 & 0.09064 & 0.262237 & 0.707145 & 0.706847 & 80 & 0.7068 \\
\hline $907-24 U$ & $46^{\circ} 47.233^{\prime}$ & $115^{\circ} 13.142^{\prime}$ & 58.70 & 295.0 & 0.19898 & 0.575902 & 0.711140 & 0.710608 & 65 & 0.7106 \\
\hline $907-26 \mathrm{I}$ & $46^{\circ} 40.495^{\prime}$ & $115^{\circ} 03.534^{\prime}$ & 135 & 249 & 0.54217 & 1.568849 & 0.709123 & 0.707674 & 65 & 0.7077 \\
\hline $907-26 \mathrm{~J}$ & $46^{\circ} 40.290^{\prime}$ & $115^{\circ} 04.536^{\prime}$ & 121 & 233 & 0.51931 & 1.502695 & 0.708994 & 0.707606 & 65 & 0.7076 \\
\hline $907-27 \mathrm{E}$ & $46^{\circ} 45.317^{\prime}$ & $115^{\circ} 22.721^{\prime}$ & 192 & 21.5 & 8.93023 & 25.877962 & 0.723741 & 0.705361 & 50 & 0.7054 \\
\hline $907-27 G$ & $46^{\circ} 47.491^{\prime}$ & $115^{\circ} 26.458^{\prime}$ & 32.4 & 353 & 0.09178 & 0.266112 & 0.729097 & 0.728851 & 65 & 0.7289 \\
\hline $907-27 N$ & $46^{\circ} 50.413^{\prime}$ & $115^{\circ} 37.277^{\prime}$ & 144.0 & 255 & 0.56471 & 1.633862 & 0.707856 & 0.706347 & 65 & 0.7063 \\
\hline $907-28 A$ & $46^{\circ} 42.426^{\prime}$ & $115^{\circ} 19.509^{\prime}$ & 51.6 & 650 & 0.07938 & 0.229683 & 0.707848 & 0.707636 & 65 & 0.7076 \\
\hline 907-28B & $46^{\circ} 40.941^{\prime}$ & $115^{\circ} 22.045^{\prime}$ & 69.8 & 686 & 0.10175 & 0.294367 & 0.707021 & 0.706749 & 65 & 0.7067 \\
\hline $907-28 C$ & $46^{\circ} 37.583^{\prime}$ & $115^{\circ} 29.204^{\prime}$ & 322 & 40.1 & 8.02993 & 23.269135 & 0.723775 & 0.707248 & 50 & 0.7072 \\
\hline 907-28D & $46^{\circ} 40.34^{\prime}$ & $115^{\circ} 33.121^{\prime}$ & 230 & 67.3 & 3.41753 & 9.891802 & 0.711851 & 0.704825 & 50 & 0.7048 \\
\hline $907-28 \mathrm{E}$ & $46^{\circ} 43.929^{\prime}$ & $115^{\circ} 33.146^{\prime}$ & 180 & 20.0 & 9.00000 & 26.079324 & 0.723423 & 0.704900 & 50 & 0.7049 \\
\hline $907-28 G$ & $46^{\circ} 49.03^{\prime}$ & $115^{\circ} 38.49^{\prime}$ & 34.9 & 571 & 0.06112 & 0.176790 & 0.704942 & 0.704779 & 65 & 0.7048 \\
\hline $907-28 \mathrm{H}$ & $46^{\circ} 43.525^{\prime}$ & $115^{\circ} 47.808^{\prime}$ & 39.6 & 788 & 0.05025 & 0.145405 & 0.708238 & 0.708104 & 65 & 0.7081 \\
\hline 90RL21 & $46^{\circ} 38.74^{\prime}$ & $115^{\circ} 10.30^{\prime}$ & 95.60 & 124.0 & 0.77097 & 2.231361 & 0.71117 & 0.709585 & 50 & 0.7096 \\
\hline 90RL94 & $46^{\circ} 27.02^{\prime}$ & $115^{\circ} 13.72^{\prime}$ & 66.00 & 970.0 & 0.06804 & 0.196889 & 0.70916 & 0.708978 & 65 & 0.7090 \\
\hline 90TF018 & $46^{\circ} 41.561^{\prime}$ & $115^{\circ} 20.099^{\prime}$ & 41.50 & 576.0 & 0.07205 & 0.208464 & 0.70817 & 0.707977 & 65 & 0.7080 \\
\hline 90TF036 & $46^{\circ} 48.999^{\prime}$ & $115^{\circ} 38.487^{\prime}$ & 28.20 & 594.0 & 0.04747 & 0.137319 & 0.70490 & 0.704802 & 50 & 0.7048 \\
\hline 90TF041 & $46^{\circ} 40.041^{\prime}$ & $115^{\circ} 01.177^{\prime}$ & 66.70 & 616.0 & 0.10828 & 0.313313 & 0.70879 & 0.708523 & 60 & 0.7085 \\
\hline 90TF053 & $46^{\circ} 50.413^{\prime}$ & $115^{\circ} 37.234^{\prime}$ & 141.00 & 261.0 & 0.54023 & 1.563028 & 0.70774 & 0.706630 & 50 & 0.7066 \\
\hline 90TF098 & $46^{\circ} 31.908^{\prime}$ & $115^{\circ} 02.976^{\prime}$ & 189.00 & 60.3 & 3.13433 & 9.073930 & 0.71393 & 0.707485 & 50 & 0.7075 \\
\hline 90TF111A & $46^{\circ} 26.249^{\prime}$ & $115^{\circ} 13.482^{\prime}$ & 73.80 & 614.0 & 0.12020 & 0.347750 & 0.70754 & 0.707219 & 65 & 0.7072 \\
\hline 90TF111B & $46^{\circ} 26.25^{\prime}$ & $115^{\circ} 13.48^{\prime}$ & 67.00 & 839.0 & 0.07986 & 0.231075 & 0.70898 & 0.708767 & 65 & 0.7088 \\
\hline $90 \mathrm{TF} 112$ & $46^{\circ} 27.157^{\prime}$ & $115^{\circ} 14.893^{\prime}$ & 83.70 & 550.0 & 0.15218 & 0.440206 & 0.70551 & 0.705104 & 65 & 0.7051 \\
\hline 90TF118 & $46^{\circ} 38.274^{\prime}$ & $115^{\circ} 25.898^{\prime}$ & 47.90 & 595.0 & 0.08050 & 0.232945 & 0.70883 & 0.708565 & 80 & 0.7086 \\
\hline 91B022a & $46^{\circ} 12.43^{\prime}$ & $115^{\circ} 35.16^{\prime}$ & 44.20 & 534.0 & 0.08277 & 0.239570 & 0.71157 & 0.711281 & 85 & 0.7113 \\
\hline
\end{tabular}




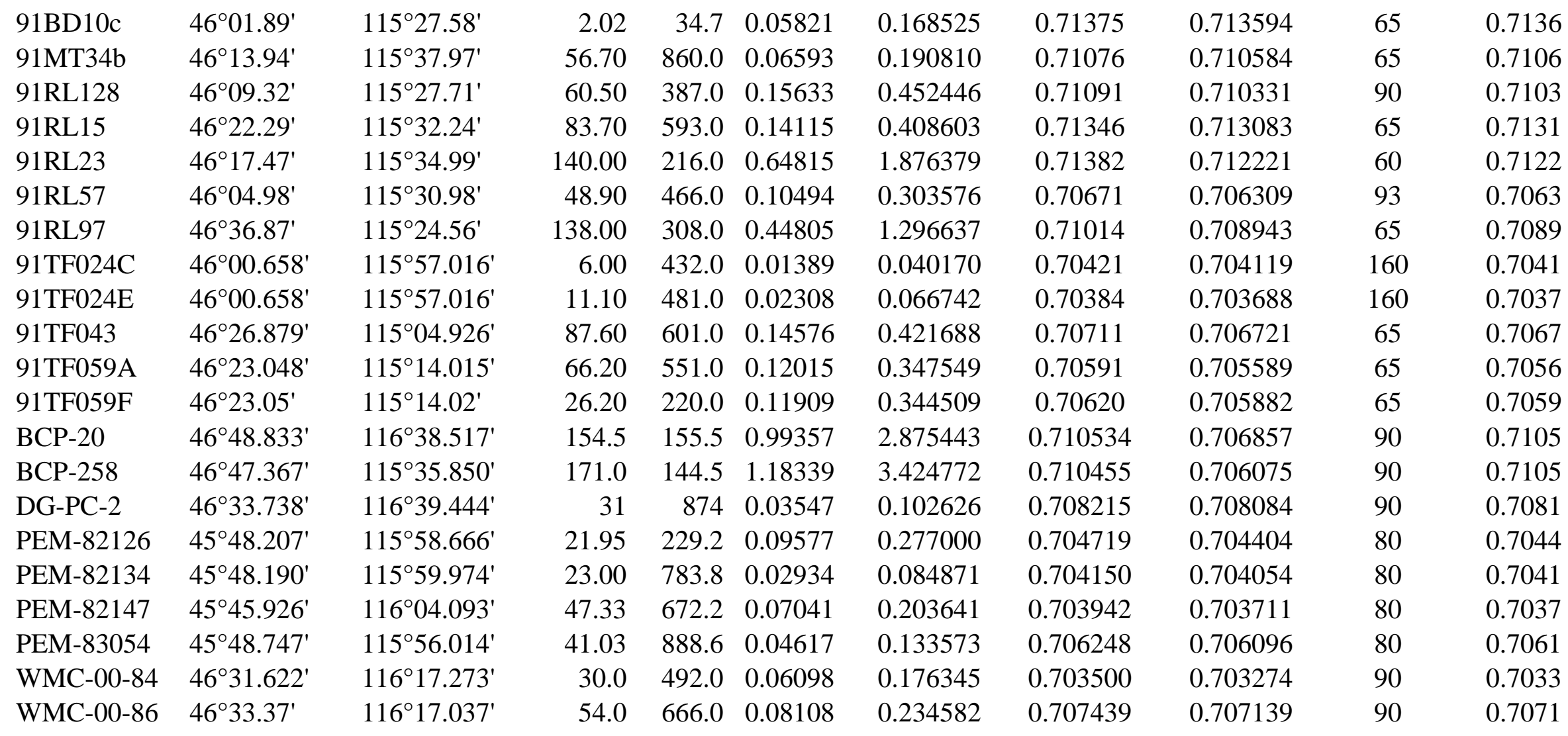


Table 2. Results of Sm-Nd Analyses

\begin{tabular}{|c|c|c|c|c|c|c|c|}
\hline Sample & $\mathrm{Nd}(\mathrm{ppm})$ & Sm (ppm) & $\mathrm{Sm} / \mathrm{Nd}$ & ${ }^{147} \mathrm{Sm} /{ }^{144} \mathrm{Nd}$ & ${ }^{143} \mathrm{Nd} /{ }^{144} \mathrm{Nd}$ & $\mathrm{E}_{\mathrm{Nd}(\mathrm{t})}$ & $\mathrm{E}_{\mathrm{Sr}(\mathrm{t})}$ \\
\hline $877-12 B$ & 29.88 & 4.69 & 0.1569 & 0.09488 & 0.512322 & -5.23 & 31.99 \\
\hline $877-12 \mathrm{C}$ & 30.01 & 4.81 & 0.1602 & 0.09685 & 0.512293 & -5.81 & 29.30 \\
\hline 877-12D & 50.64 & 7.99 & 0.1578 & 0.09542 & 0.512310 & -5.47 & 29.72 \\
\hline $877-12 E$ & 22.17 & 2.05 & 0.0923 & 0.05577 & 0.512198 & -7.27 & 50.04 \\
\hline $877-12 G$ & 20.62 & 3.31 & 0.1605 & 0.09699 & 0.512085 & -9.87 & 65.07 \\
\hline $877-12 \mathrm{I}$ & 14.68 & 2.44 & 0.1659 & 0.10032 & 0.512312 & -5.48 & 12.38 \\
\hline 877-13B & 29.44 & 4.11 & 0.1397 & 0.08447 & 0.512162 & -8.18 & 41.56 \\
\hline 877-13C & 87.53 & 21.47 & 0.2453 & 0.14826 & 0.511857 & -14.78 & 1022.8 \\
\hline 877-13D & 57.41 & 11.64 & 0.2027 & 0.12254 & 0.511516 & -21.17 & 448.6 \\
\hline 877-13E & 167.81 & 16.82 & 0.1002 & 0.06058 & 0.512098 & -9.18 & 195.8 \\
\hline 877-13G & 22.20 & 3.68 & 0.1658 & 0.10020 & 0.510824 & -34.45 & 798.3 \\
\hline $887-22 \mathrm{~A}$ & 132.62 & 21.89 & 0.1650 & 0.09975 & 0.512115 & -9.25 & 151.8 \\
\hline $887-22 B$ & 22.13 & 5.94 & 0.2687 & 0.16240 & 0.511944 & -13.23 & \\
\hline $887-22 \mathrm{C}$ & 51.15 & 6.19 & 0.1210 & 0.07314 & 0.512071 & -9.84 & 50.75 \\
\hline 887-22D & 113.77 & 15.11 & 0.1328 & 0.08030 & 0.512125 & -8.86 & 1323.8 \\
\hline $887-24 A$ & 33.94 & 7.16 & 0.2108 & 0.12744 & 0.512664 & 1.71 & 0.65 \\
\hline 887-24B & 16.32 & 2.74 & 0.1680 & 0.10154 & 0.512825 & 5.31 & -10.90 \\
\hline $887-24 C$ & 7.47 & 1.78 & 0.2377 & 0.14373 & 0.512926 & 6.53 & -9.03 \\
\hline 887-24D & 6.83 & 1.40 & 0.2048 & 0.12382 & 0.512870 & 5.79 & -9.75 \\
\hline $887-24 \mathrm{E}$ & 10.74 & 3.53 & 0.3289 & 0.19884 & 0.512857 & 4.20 & 9.65 \\
\hline $887-24 \mathrm{~F}$ & 34.89 & 7.41 & 0.2124 & 0.12839 & 0.512729 & 2.96 & -4.03 \\
\hline $887-24 G$ & 44.00 & 9.12 & 0.2072 & 0.12530 & 0.512755 & 3.52 & -4.63 \\
\hline $887-24 \mathrm{H}$ & 10.66 & 2.23 & 0.2096 & 0.12672 & 0.512773 & 3.85 & 3.52 \\
\hline $887-24 \mathrm{I}$ & 14.52 & 2.76 & 0.1899 & 0.11482 & 0.512670 & 2.05 & 0.72 \\
\hline $887-24 \mathrm{~J}$ & 12.86 & 2.42 & 0.1884 & 0.11391 & 0.512503 & -1.19 & -1.29 \\
\hline $887-25 B$ & 20.39 & 3.04 & 0.1490 & 0.09009 & 0.512276 & -6.01 & 42.12 \\
\hline $887-25 C$ & 45.13 & 7.88 & 0.1745 & 0.10549 & 0.512222 & -7.22 & 42.34 \\
\hline 887-25D & 51.98 & 8.96 & 0.1723 & 0.10418 & 0.512200 & -7.64 & 42.90 \\
\hline $887-25 E$ & 34.92 & 5.56 & 0.1592 & 0.09621 & 0.512211 & -7.34 & 40.70 \\
\hline $887-25 F$ & 51.25 & 9.55 & 0.1864 & 0.11269 & 0.512206 & -7.61 & 42.34 \\
\hline $887-25 G$ & 33.21 & 4.80 & 0.1445 & 0.08734 & 0.512301 & -5.50 & 34.40 \\
\hline $887-25 \mathrm{H}$ & 21.10 & 3.19 & 0.1513 & 0.09143 & 0.512314 & -5.29 & 32.44 \\
\hline $887-25 I$ & 3.73 & 1.05 & 0.2816 & 0.17025 & 0.512433 & -3.77 & 31.06 \\
\hline $887-25 \mathrm{~J}$ & 13.45 & 2.23 & 0.1659 & 0.10027 & 0.512297 & -5.71 & 34.67 \\
\hline
\end{tabular}

Note: Epsilon values and initial ratios are based on an age of $80 \mathrm{Ma}$ 
Table 3. K-Ar Apparent Ages of Rocks of Western Idaho

\begin{tabular}{|c|c|c|c|c|c|}
\hline Sample \# & Material & $\mathrm{K}_{2} \mathrm{O}(\%)$ & $\mathrm{mol}{ }^{40} \mathrm{Ar} * / \mathrm{g}$ & ${ }^{40} \mathrm{Ar}^{*}$ & Mean Age (Ma) \\
\hline \multirow{4}{*}{$807-27 \mathrm{~A}$} & $\mathrm{Pl}$ & $0.180,0.174$ & 2.01E-11 & 41.0 & $76.56 \pm 0.75$ \\
\hline & & & $1.97 \mathrm{E}-11$ & 40.6 & \\
\hline & $\mathrm{Bi}$ & $9.28,9.28$ & 1.06E-09 & 88.2 & $77.65 \pm 0.30$ \\
\hline & & & 1.06E-09 & 79.3 & \\
\hline \multirow[t]{4}{*}{ 807-30I } & $\mathrm{Bi}$ & $9.64,9.65$ & $9.80 \mathrm{E}-10$ & 85.4 & $69.04 \pm 0.19$ \\
\hline & & & $9.75 \mathrm{E}-10$ & 68.0 & \\
\hline & $\mathrm{Mu}$ & $10.71,10.65$ & 1.13E-09 & 85.1 & $71.78 \pm 0.34$ \\
\hline & & & $1.12 \mathrm{E}-09$ & 65.6 & \\
\hline \multirow[t]{2}{*}{ 807-31A } & $\mathrm{Hb}$ & 1.194, 1.181 & $1.44 \mathrm{E}-10$ & 77.3 & $84.86 \pm 2.73$ \\
\hline & & & 1.53E-10 & 82.3 & \\
\hline \multirow[t]{2}{*}{ 808-1I } & $\mathrm{Hb}$ & $1.521,1.550$ & 1.76E-10 & 74.2 & $79.61 \pm 1.49$ \\
\hline & & & $1.83 \mathrm{E}-10$ & 84.8 & \\
\hline \multirow[t]{4}{*}{ 818-11G } & $\mathrm{Bi}$ & $9.49,9.39$ & 8.72E-10 & 78.2 & $63.75 \pm 0.69$ \\
\hline & & & 8.91E-10 & 78.0 & \\
\hline & $\mathrm{Hb}$ & $0.701,0.701$ & 8.10E-11 & 66.4 & $80.16 \pm 1.60$ \\
\hline & & & 8.44E-11 & 59.8 & \\
\hline \multirow[t]{2}{*}{$818-12 E$} & $\mathrm{Hb}$ & $0.281,0.276$ & 2.64E-11 & 36.2 & $67.21 \pm 2.58$ \\
\hline & & & 2.85E-11 & 23.1 & \\
\hline \multirow[t]{3}{*}{ 818-13A } & $\mathrm{Bi}$ & $9.82,9.86$ & $1.08 \mathrm{E}-09$ & 82.2 & $74.04 \pm 0.86$ \\
\hline & & & 1.06E-09 & 86.4 & \\
\hline & $\mathrm{Hb}$ & 1.539, 1.552 & $1.71 \mathrm{E}-10$ & 79.7 & $75.22 \pm 0.60$ \\
\hline \multirow[t]{4}{*}{ 818-13C } & $\mathrm{Bi}$ & $8.74,8.68$ & 8.71E-10 & 79.2 & $67.99 \pm 0.18$ \\
\hline & & & $8.67 \mathrm{E}-10$ & 68.0 & \\
\hline & $\mathrm{Mu}$ & $10.68,10.65$ & $1.04 \mathrm{E}-09$ & 91.5 & $66.95 \pm 0.34$ \\
\hline & & & $1.05 \mathrm{E}-09$ & 87.6 & \\
\hline \multirow[t]{4}{*}{ 818-13D } & $\mathrm{Bi}$ & $9.13,9.18$ & $9.35 \mathrm{E}-10$ & 74.1 & $70.43 \pm 0.85$ \\
\hline & & & $9.58 \mathrm{E}-10$ & 85.8 & \\
\hline & $\mathrm{Mu}$ & $10.96,10.94$ & $1.21 \mathrm{E}-09$ & 96.0 & $75.27 \pm 0.12$ \\
\hline & & & $1.21 \mathrm{E}-09$ & 86.1 & \\
\hline \multirow[t]{4}{*}{ 818-13E } & $\mathrm{Bi}$ & $9.62,9.66$ & $1.06 \mathrm{E}-09$ & 76.2 & $74.27 \pm 0.53$ \\
\hline & & & $1.04 \mathrm{E}-09$ & 79.0 & \\
\hline & $\mathrm{Mu}$ & $10.48,10.51$ & $1.14 \mathrm{E}-09$ & 87.9 & $72.91 \pm 1.05$ \\
\hline & & & $1.11 \mathrm{E}-09$ & 91.7 & \\
\hline \multirow[t]{4}{*}{$827-27 \mathrm{~F}$} & $\mathrm{Hb}$ & $0.848,0.858$ & 8.89E-11 & 40.4 & $72.82 \pm 1.93$ \\
\hline & & & $9.52 \mathrm{E}-11$ & 66.4 & \\
\hline & & & 9.15E-11 & 68.2 & \\
\hline & & & 8.94E-11 & 63.0 & \\
\hline \multirow[t]{3}{*}{ 827-30C } & $\mathrm{Hb}$ & $1.004,1.004$ & $1.45 \mathrm{E}-10$ & 58.3 & $97.69 \pm 1.33$ \\
\hline & & & $1.48 \mathrm{E}-10$ & 71.9 & \\
\hline & & & $1.43 \mathrm{E}-10$ & 44.7 & \\
\hline
\end{tabular}




\begin{tabular}{|c|c|c|c|c|c|}
\hline \multirow[t]{4}{*}{$827-30 \mathrm{~K}$} & \multirow[t]{2}{*}{$\mathrm{Bi}$} & \multirow[t]{2}{*}{ 9.53, 9.54} & $1.08 \mathrm{E}-09$ & 69.4 & \multirow[t]{2}{*}{$77.37 \pm 0.08$} \\
\hline & & & 1.09E-09 & 84.6 & \\
\hline & \multirow[t]{2}{*}{$\mathrm{Hb}$} & \multirow[t]{2}{*}{$1.428,1.433$} & $1.51 \mathrm{E}-10$ & 58.7 & \multirow[t]{2}{*}{$71.10 \pm 0.71$} \\
\hline & & & $1.48 \mathrm{E}-10$ & 62.1 & \\
\hline \multirow[t]{5}{*}{ 837-23B } & \multirow[t]{3}{*}{$\mathrm{Bi}$} & \multirow[t]{3}{*}{$8.10,8.38$} & 8.38E-10 & 82.8 & \multirow[t]{3}{*}{$73.17 \pm 3.48$} \\
\hline & & & 9.43E-10 & 65.8 & \\
\hline & & & 8.77E-10 & 82.0 & \\
\hline & \multirow[t]{2}{*}{$\mathrm{Hb}$} & \multirow[t]{2}{*}{$0.927,0.911$} & $1.04 \mathrm{E}-10$ & 68.6 & \multirow[t]{2}{*}{$77.62 \pm 0.81$} \\
\hline & & & $1.06 \mathrm{E}-10$ & 81.2 & \\
\hline \multirow[t]{5}{*}{$837-24 A$} & \multirow[t]{2}{*}{$\mathrm{Bi}$} & \multirow[t]{2}{*}{$9.49,9.44$} & 9.93E-10 & 79.6 & \multirow[t]{2}{*}{$71.55 \pm 0.10$} \\
\hline & & & $9.96 \mathrm{E}-10$ & 82.6 & \\
\hline & \multirow[t]{3}{*}{$\mathrm{Hb}$} & \multirow[t]{3}{*}{$1.347,1.353$} & $1.50 \mathrm{E}-10$ & 60.3 & \multirow[t]{3}{*}{$76.38 \pm 1.62$} \\
\hline & & & $1.56 \mathrm{E}-10$ & 84.2 & \\
\hline & & & $1.48 \mathrm{E}-10$ & 79.9 & \\
\hline \multirow[t]{3}{*}{ 837-24D } & \multirow[t]{3}{*}{$\mathrm{Hb}$} & \multirow[t]{3}{*}{$0.376,0.377$} & 3.94E-11 & 34.5 & \multirow[t]{3}{*}{$70.20 \pm 0.84$} \\
\hline & & & 3.82E-11 & 49.5 & \\
\hline & & & 3.89E-11 & 37.8 & \\
\hline $837-25 C$ & $\mathrm{Bi}$ & $9.41,9.34$ & 8.01E-10 & 63.3 & $58.59 \pm 0.20$ \\
\hline & & & 8.06E-10 & 70.5 & \\
\hline & $\mathrm{Mu}$ & $10.48,10.51$ & $9.68 \mathrm{E}-10$ & 75.1 & $62.66 \pm 0.28$ \\
\hline & & & $9.59 \mathrm{E}-10$ & 72.5 & \\
\hline $837-25 E$ & $\mathrm{Bi}$ & $9.50,9.45$ & 9.83E-10 & 88.2 & $70.81 \pm 0.17$ \\
\hline & & & 9.87E-10 & 88.0 & \\
\hline & $\mathrm{Hb}$ & $0.499,0.492$ & 6.73E-11 & 32.6 & $91.24 \pm 0.74$ \\
\hline & & & $6.62 \mathrm{E}-11$ & 47.2 & \\
\hline 837-26D & $\mathrm{Bi}$ & 9.29, 9.54, & $9.90 \mathrm{E}-10$ & 76.6 & $71.97 \pm 1.22$ \\
\hline & & 9.34, 9.37 & 9.73E-10 & 66.4 & \\
\hline & & & 9.91E-10 & 75.5 & \\
\hline & & & 1.01E-09 & 84.8 & \\
\hline & $\mathrm{Hb}$ & $1.538,1.549$ & $1.80 \mathrm{E}-10$ & 60.0 & $76.46 \pm 2.07$ \\
\hline & & & $1.71 \mathrm{E}-10$ & 74.3 & \\
\hline & & & 1.69E-10 & 75.1 & \\
\hline 837-27I & $\mathrm{Bi}$ & 8.33, 8.32 & $6.14 \mathrm{E}-10$ & 72.8 & $50.46 \pm 0.08$ \\
\hline & & & $6.12 \mathrm{E}-10$ & 72.3 & \\
\hline 837-28B & $\mathrm{Bi}$ & $9.71,9.72$ & 1.05E-09 & 81.0 & $74.16 \pm 0.30$ \\
\hline & & & 1.06E-09 & 78.8 & \\
\hline & $\mathrm{Hb}$ & $1.968,1.846$ & 2.32E-10 & 83.1 & \\
\hline $837-28 C$ & $\mathrm{Bi}$ & $9.65,9.67$ & 1.08E-09 & 75.2 & $76.02 \pm 0.30$ \\
\hline & & & 1.08E-09 & 88.8 & \\
\hline $837-28 F$ & $\mathrm{Bi}$ & $9.86,9.83$ & 1.19E-09 & 72.5 & $78.36 \pm 2.16$ \\
\hline & & & 1.13E-09 & 90.3 & \\
\hline & & & 1.11E-09 & 91.0 & \\
\hline & & & 1.11E-09 & 87.6 & \\
\hline
\end{tabular}




\begin{tabular}{|c|c|c|c|c|c|}
\hline \multirow[t]{4}{*}{$837-29 G$} & \multirow[t]{2}{*}{$\mathrm{Bi}$} & \multirow[t]{2}{*}{$8.84,8.92$} & 1.13E-09 & 51.8 & \multirow[t]{2}{*}{$87.67 \pm 1.63$} \\
\hline & & & 1.17E-09 & 91.7 & \\
\hline & \multirow{2}{*}{$\mathrm{Hb}$} & \multirow{2}{*}{$1.21,1.189$} & $1.72 \mathrm{E}-10$ & 50.5 & \multirow{2}{*}{$100.91 \pm 4.04$} \\
\hline & & & $1.87 \mathrm{E}-10$ & 84.7 & \\
\hline \multirow[t]{2}{*}{ 837-30A } & \multirow[t]{2}{*}{$\mathrm{Hb}$} & \multirow[t]{2}{*}{$0.611,0.609$} & 9.33E-11 & 72.4 & \multirow[t]{2}{*}{$101.89 \pm 2.35$} \\
\hline & & & 9.78E-11 & 74.9 & \\
\hline \multirow[t]{2}{*}{ 837-30C } & \multirow[t]{2}{*}{$\mathrm{Bi}$} & \multirow[t]{2}{*}{$8.46,8.42$} & $1.02 \mathrm{E}-09$ & 70.4 & \multirow[t]{2}{*}{$82.43 \pm 0.43$} \\
\hline & & & 1.03E-09 & 83.2 & \\
\hline \multirow{4}{*}{$837-31 \mathrm{E}$} & \multirow[t]{2}{*}{$\mathrm{Bi}$} & \multirow{2}{*}{$9.10,9.13$} & 1.08E-09 & 89.3 & \multirow{2}{*}{$80.72 \pm 0.15$} \\
\hline & & & 1.09E-09 & 87.4 & \\
\hline & \multirow[t]{2}{*}{$\mathrm{Hb}$} & \multirow{2}{*}{$1.461,1.453$} & $1.89 \mathrm{E}-10$ & 69.6 & \multirow[t]{2}{*}{$85.74 \pm 2.36$} \\
\hline & & & 1.79E-09 & 30.2 & \\
\hline \multirow{6}{*}{ 837-31I } & \multirow[t]{2}{*}{$\mathrm{Bi}$} & \multirow{2}{*}{$9.51,9.46$} & 1.09E-09 & 86.8 & \multirow{2}{*}{$78.97 \pm 0.75$} \\
\hline & & & 1.11E-09 & 89.8 & \\
\hline & \multirow{4}{*}{$\mathrm{Hb}$} & \multirow{4}{*}{$1.653,1.655$} & $1.92 \mathrm{E}-10$ & 82.2 & \multirow{4}{*}{$81.80 \pm 3.04$} \\
\hline & & & $2.09 \mathrm{E}-10$ & 78.2 & \\
\hline & & & $2.04 \mathrm{E}-10$ & 87.6 & \\
\hline & & & $1.92 \mathrm{E}-10$ & 57.0 & \\
\hline \multirow[t]{4}{*}{ 837-31L } & \multirow[t]{2}{*}{$\mathrm{Bi}$} & $9.42,9.42$ & $1.08 \mathrm{E}-09$ & 80.6 & $78.70 \pm 0.69$ \\
\hline & & & $1.10 \mathrm{E}-09$ & 78.2 & \\
\hline & $\mathrm{Hb}$ & $0.996,1.001$ & 1.19E-10 & 52.5 & $79.56 \pm 1.38$ \\
\hline & & & $1.15 \mathrm{E}-10$ & 42.9 & \\
\hline 838-2I & $\mathrm{Bi}$ & $9.59,9.61$ & 1.06E-09 & 83.5 & $76.04 \pm 0.61$ \\
\hline & & & $1.08 \mathrm{E}-09$ & 85.6 & \\
\hline & $\mathrm{Hb}$ & $1.512,1.521$ & $1.70 \mathrm{E}-10$ & 81.4 & $78.49 \pm 2.24$ \\
\hline & & & $1.82 \mathrm{E}-10$ & 78.9 & \\
\hline & & & $1.73 \mathrm{E}-10$ & 82.2 & \\
\hline $838-3 C$ & $\mathrm{Bi}$ & $9.79,9.75$ & $1.02 \mathrm{E}-09$ & 68.0 & $71.34 \pm 0.20$ \\
\hline & & & 1.03E-09 & 88.6 & \\
\hline & $\mathrm{Hb}$ & $1.419,1.424$ & $1.57 \mathrm{E}-10$ & 69.3 & $74.74 \pm 0.32$ \\
\hline & & & 1.55E-10 & 75.9 & \\
\hline
\end{tabular}

* Radiogenic

+ Age calc. using decay constants of Steiger and Jäger, 1977. 
Table 4. Results of ${ }^{40} \mathrm{Ar} /{ }^{39} \mathrm{Ar}$ Ages

\begin{tabular}{|c|c|c|c|c|c|c|c|c|c|c|c|}
\hline Sample & Temp $\left({ }^{\circ} \mathrm{C}\right)$ & Mineral & $\%{ }^{39} \mathrm{Ar}$ & $\%{ }^{40} \mathrm{Ar}$ & $\%{ }^{36} \mathrm{Ar}_{\mathrm{Ca}}$ & ${ }^{40} \mathrm{Ar} /{ }^{39} \mathrm{Ar}$ & ${ }^{37} \mathrm{Ar} /{ }^{39} \mathrm{Ar}$ & ${ }^{36} \mathrm{Ar} /{ }^{39} \mathrm{Ar}$ & J-Value & Age (Ma) & +/- (Ma) \\
\hline \multirow[t]{11}{*}{$827-27 F$} & $700^{+}$ & Hornblende & 0.42 & 9.4 & 0.09 & 190.33 & 1.917 & 0.5842 & 0.0051775 & 159.66 & 14.36 \\
\hline & $800^{+}$ & do. & 0.33 & 6.4 & 0.13 & 200.69 & 3.019 & 0.6365 & 0.0051775 & 116.30 & 19.08 \\
\hline & $875^{+}$ & do. & 0.90 & 5.7 & 0.31 & 134.84 & 4.877 & 0.4315 & 0.0051775 & 70.90 & 6.68 \\
\hline & $930^{+}$ & do. & 1.49 & 11.5 & 0.81 & 62.21 & 5.622 & 0.1879 & 0.0051775 & 65.78 & 3.72 \\
\hline & 955 & do. & 7.40 & 50.5 & 5.83 & 15.56 & 5.928 & 0.0277 & 0.0051775 & 72.19 & 0.84 \\
\hline & 980 & do. & 5.86 & 50.0 & 5.70 & 15.79 & 5.928 & 0.0283 & 0.0051775 & 72.59 & 0.98 \\
\hline & 1005 & do. & 7.37 & 50.7 & 5.82 & 15.60 & 5.906 & 0.0276 & 0.0051775 & 72.75 & 0.85 \\
\hline & 1155 & do. & 75.85 & 92.3 & 41.59 & 8.73 & 5.867 & 0.0038 & 0.0051775 & 74.08 & 0.43 \\
\hline & Fuse & do. & 0.38 & 27.8 & 2.30 & 27.37 & 5.779 & 0.0684 & 0.0051775 & 69.91 & 12.67 \\
\hline & & & & & & & & \multicolumn{2}{|c|}{ Recalculated total (Ma)- } & \multicolumn{2}{|l|}{74.1} \\
\hline & & & & & & & & \multicolumn{2}{|c|}{ Plateau age (Ma)-------- } & \multicolumn{2}{|c|}{$73.4 \pm 0.4$} \\
\hline \multirow[t]{11}{*}{ 837-23B } & $700^{+}$ & Hornblende & 0.58 & 9.4 & 0.56 & 153.30 & 9.785 & 0.4727 & 0.0051775 & 130.61 & 9.58 \\
\hline & $830^{+}$ & do. & 0.92 & 6.0 & 0.15 & 116.92 & 2.096 & 0.3726 & 0.0051775 & 64.16 & 6.14 \\
\hline & $895^{+}$ & do. & 1.67 & 10.9 & 0.48 & 67.00 & 3.608 & 0.2030 & 0.0051775 & 67.11 & 3.42 \\
\hline & 940 & do. & 8.71 & 65.7 & 8.86 & 12.62 & 5.234 & 0.0161 & 0.0051775 & 76.04 & 0.72 \\
\hline & 955 & do. & 13.98 & 77.6 & 15.50 & 10.62 & 5.418 & 0.0095 & 0.0051775 & 75.59 & 0.56 \\
\hline & 995 & do. & 28.13 & 87.4 & 26.83 & 9.49 & 5.435 & 0.0055 & 0.0051775 & 76.12 & 0.47 \\
\hline & 1060 & do. & 43.79 & 91.3 & 36.25 & 9.15 & 5.555 & 0.0042 & 0.0051775 & 76.66 & 0.45 \\
\hline & 1095 & do. & 2.33 & 63.7 & 8.63 & 13.02 & 5.546 & 0.0175 & 0.0051775 & 76.16 & 2.33 \\
\hline & Fuse & do. & 0.21 & 12.3 & 0.81 & 57.83 & 5.163 & 0.1729 & 0.0051775 & 65.63 & 23.10 \\
\hline & & & & & & & & \multirow{2}{*}{\multicolumn{2}{|c|}{$\begin{array}{l}\text { Recalculated total (Ma)- } \\
\text { Plateau age (Ma)--------- }\end{array}$}} & \multirow{2}{*}{\multicolumn{2}{|c|}{$\begin{array}{l}76.3 \\
76.2 \pm 0.2\end{array}$}} \\
\hline & & & & & & & & & & & \\
\hline \multirow[t]{3}{*}{ 837-28B } & $\mathrm{TF}$ & Hornblende & 100.00 & 90.2 & 28.64 & 9.40 & 4.765 & 0.0042 & 0.005414 & 81.29 & 0.54 \\
\hline & $\mathrm{TF}$ & do. & 100.00 & 90.9 & 28.74 & 9.25 & 4.347 & 0.0038 & 0.005414 & 80.55 & 0.60 \\
\hline & $\mathrm{TF}$ & do. & 100.00 & 89.9 & 28.87 & 9.48 & 5.024 & 0.0044 & 0.005414 & 81.67 & 0.56 \\
\hline
\end{tabular}




\begin{tabular}{|c|c|c|c|c|c|c|c|c|c|c|c|}
\hline & $\mathrm{TF}$ & do. & 100.00 & 92.7 & 33.59 & 9.37 & 4.377 & 0.0033 & 0.005414 & 83.14 & 0.54 \\
\hline & $\mathrm{TF}$ & do. & 100.00 & 93.0 & 32.63 & 9.39 & 4.059 & 0.0031 & 0.005414 & 83.53 & 0.61 \\
\hline & $\mathrm{TF}$ & do. & 100.00 & 92.1 & 31.01 & 9.60 & 4.337 & 0.0035 & 0.005414 & 84.64 & 0.58 \\
\hline & & & & & & & & \multicolumn{2}{|c|}{$\begin{array}{l}\text { Weighted mean (Ma)---- } \\
\text { MSWD ---------- }\end{array}$} & \multicolumn{2}{|c|}{$\begin{array}{l}82.5 \pm 0.2 \\
7.12\end{array}$} \\
\hline 837-30A & $\mathrm{TF}$ & Hornblende & 100.00 & 78.7 & 15.41 & 15.88 & 7.873 & 0.0135 & 0.004749 & 104.61 & 0.89 \\
\hline 837- & & & & & & & & & & & \\
\hline \multirow[t]{9}{*}{$30 \mathrm{~A}(\mathrm{IH})$} & 750 & Hornblende & 0.28 & 0.01 & 0.09 & 303.59 & 3.343 & 1.0281 & 0.004749 & 0.28 & 140.29 \\
\hline & 875 & do. & 3.57 & 15.5 & 0.96 & 70.42 & 7.419 & 0.2034 & 0.004749 & 91.51 & 3.28 \\
\hline & 940 & do. & 77.98 & 87.3 & 25.67 & 13.89 & 7.794 & 0.0080 & 0.004749 & 101.54 & 0.61 \\
\hline & 975 & do. & 17.64 & 80.8 & 18.33 & 14.70 & 8.111 & 0.0117 & 0.004749 & 99.50 & 0.74 \\
\hline & 1000 & do. & 0.08 & -13.7 & 0.17 & 215.09 & 5.185 & 0.8292 & 0.004749 & -273.62 & 168.43 \\
\hline & 1030 & do. & 0.08 & -12.0 & 0.14 & 236.68 & 4.853 & 0.8980 & 0.004749 & -261.25 & 177.29 \\
\hline & 1100 & do. & 0.09 & -8.4 & 0.13 & 280.51 & 5.207 & 1.0306 & 0.004749 & -215.50 & 178.05 \\
\hline & Fuse & do. & 0.28 & -5.6 & 0.29 & 170.15 & 6.735 & 0.6096 & 0.004749 & -83.40 & 38.60 \\
\hline & & & & & & & & \multicolumn{2}{|c|}{$\begin{array}{l}\text { Recalculated total (Ma)- } \\
\text { Plateau age (Ma)--------- }\end{array}$} & \multicolumn{2}{|c|}{$\begin{array}{l}99.3 \\
100.7 \pm 0.5\end{array}$} \\
\hline
\end{tabular}

